\title{
Análise clínica e molecular de pacientes com distúrbios do desenvolvimento gonadal
}

Tese apresentada à Faculdade de Medicina da Universidade de São Paulo para obtenção do título de Doutor em Ciências

Área de Concentração: Endocrinologia Orientadora: $\mathrm{Dr}^{\mathrm{a}}$. Elaine Maria Frade Costa

SÃO PAULO 2009 
Dados Internacionais de Catalogação na Publicação (CIP)

Preparada pela Biblioteca da

Faculdade de Medicina da Universidade de São Paulo

Creprodução autorizada pelo autor

Gomes, Camila Richieri

Análise clínica e molecular de pacientes com distúrbios do

desenvolvimento gonadal / Camila Richieri Gomes. -- São Paulo, 2009.

Tese(doutorado)--Faculdade de Medicina da Universidade de São

Paulo. Departamento de Clínica Médica.

Área de concentração: Endocrinologia.

Orientadora: Elaine Maria Frade Costa.

Descritores: 1.Disgenesia gonadal 46XX 2.Disgenesia gonadal 46XY 3.Doenças dos genitais masculinos/genética 4.Amenorréia 5.Mutação em linhagem germinativa 6.Desenvolvimento sexual 7.Transtornos gonadais 8.Infantilismo sexual

USP/FM/SBD-453/09 
Este trabalho foi realizado na Unidade

Endocrinologia do Desenvolvimento e no Laboratório de Hormônios e Genética Molecular LIM 42 da disciplina de Endocrinologia do Hospital das Clínicas da Faculdade de Medicina da Universidade de São Paulo, com apoio Fundação de Amparo à Pesquisa do Estado de São Paulo (FAPESP): Projeto Temático 0504726-0 e bolsa de doutorado 05/55732-0. 
Dedicatória 
Aos meus pais, que me trouxeram até aqui; ao Cristiano, meu amor e sempre companheiro; aos meus filhos, Dora Lígia e Luis Fernando, que fazem a minha vida mais feliz! 
Agradecimentos 
Sempre que estamos concluindo algo grande, paramos para avaliar como foi a nossa jornada. Ao final deste projeto de pesquisa, vejo que não sou mais a mesma. Cresci muito nesses quatro anos, e acho importante deixar aqui meu agradecimento a todas as pessoas que participaram do meu crescimento.

Primeiramente quero agradecer aos meus professores da Universidade Federal do Espírito Santo (UFES), onde me graduei e fiz minha residência de Pediatria. Dra. Sandra e Dra. Cecília, agradeço por vocês sempre estarem nos momentos mais delicados de minha vida e por me apoiarem sempre a crescer na minha profissão e carreira acadêmica. Agradeço também ao Dr. Chambô, que apesar de não ter sido meu professor, sempre acreditou em mim e me estimulou a continuar estudando.

Agradeço a todo o grupo da Endocrinopediatria do Instituto da Criança, Dra. Nuvarte, Dr. Durval, Dra. Thais, Dr. Vaê, Dr. Hilton, Dr. Hamilton e Dra. Leandra, aos voluntários e residentes, que estiveram no começo da minha caminhada pela endocrinologia, e me ensinaram muito sobre como atender e cuidar desses pacientes.

Ao Dr. Alexander Jorge, que acreditou no meu potencial e me trouxe até o LIM-42, e que sempre me ajudou nos trabalhos, estatísticas, casos clínicos, como se fosse uma de suas "filhas".

A todos os assistentes do ambulatório de Endocrinologia do Desenvolvimento, Dr. Ivo, Dra. Berenice, Dra. Elaine, Dra. Ana Cláudia, Dra. 
Cândida, Dra. Tânia, Dr. Alex, Dra. Sorahia, que me ensinaram que mais do que pesquisar, é preciso acolher e atender o paciente, seja ele de qual classe social, credo ou raça, com dedicação, amor e humildade.

Às psicólogas Marlene Ignácio e Elisa Verduguez, e à Dra. Maria Helena, cirurgiã amiga e também pós graduanda, que me fizeram ver a importância do atendimento global do paciente, em especial nossos pacientes com distúrbios do desenvolvimento sexual.

Ás biólogas funcionárias e pós-graduandas do LIM-42, todas elas sem exceção, Mirian, Ana Elisa, Emília, Mariana, Cris Rossi, Cidinha, Helena, Ericka, Beatriz, Tamaya, que me mostraram como a Biologia pode ser complexa e fascinante, como são competentes no que fazem, e como estão sempre prontas para tirar uma dúvida ou para nos ensinar algo de novo. Em especial agradeço a Luciana Montenegro, amiga querida e companheira de bancada, e a Mariza, que sempre estiveram mais próximas de mim me auxiliando na minha pesquisa.

Agradeço aos meus amigos pós graduandos: Rocio, Maíra, Carolina, Antônio, Ana Paula, Frederico, Luciana Brito, Maria Estela, Milena, Madson, Priscila, Larissa, Letícia, Everlayny, Alexsandra, Andrea, Aline, e orientadores Luciani, Regina e Vinícius, que estiveram cada um em sua jornada, mas sempre juntos em congressos, bancadas, um ajudando o outro, sempre para todos caminharmos em uma só direção - que é o que faz esse LIM-42 ser tão próspero. Obrigada às secretárias, Nilda, Cris e Ana, à Neide e à Fran, que estão sempre nos ajudando no que precisamos no laboratório. 
Não posso esquecer-me de minhas queridas amigas Débora e Lindiane, que sempre me acompanharam nessa grande aventura da pós graduação.

Agradeço muito à minha orientadora, Dra. Elaine Maria Frade Costa, que sempre acreditou no meu potencial, confiou em minhas decisões e teve paciência em aceitar e entender meus horários e calendários, por ela também ser além de excelente pesquisadora, mãe dedicada e presente na vida de sua família.

Agradeço em especial a Dra. Berenice, que com sua experiência e sabedoria foi capaz de criar raízes, frutos e sementes na Universidade, sempre prezando pela excelência na pesquisa e principalmente no atendimento ao paciente, e que ainda sendo grande como é, conhece cada um dos seus alunos, pacientes, e procura atendê-los com toda dedicação.

Não teria conseguido chegar até aqui se não fossem meus pais, que sempre me estimularam a estudar o que estivesse interessada, e por isso abriram um mundo de possibilidades do qual agora estou desfrutando. Espero poder criar para meus filhos as oportunidades que vocês criaram para mim. Amo vocês!

Agradeço ao meu marido, companheiro de alegrias e de dificuldades, sempre disposto a lutar, aprender, e graças à sua energia e disposição para enfrentar o novo que estamos aqui, em São Paulo, e que cheguei aqui, no doutorado. Obrigada por entender minhas ausências, minhas viagens a congressos, meus plantões a menos para poder estar no laboratório; isso fez TODA a diferença. Amo você. 
Obrigada aos meus filhos, por existirem e tornarem minha vida mais alegre, mais especial. É a energia de que preciso para levantar todos os dias e querer crescer, estudar, trabalhar, ser alguém melhor. Obrigada aos meus amigos, "caatingueiros", "SOTINSPzeiros", "junta-pizzeiros", companheiros de alegrias e de tempos difíceis. Agradeço também a todos os meus familiares, avós, primos, tios, à minha irmã querida, que sempre tiveram orgulho de minha vida acadêmica e sempre me trataram com muito amor.

E finalmente, agradeço a Deus por estar aqui, com saúde, produzindo, e espero poder contribuir de alguma forma para que esse mundo seja melhor, em gratidão a tudo que Ele já me proporcionou e continua me presenteando. Obrigada! 
Sumário 
Lista de Abreviaturas

Lista de Símbolos

Lista de Figuras

Lista de Tabelas

Lista de Anexos

Resumo

Summary

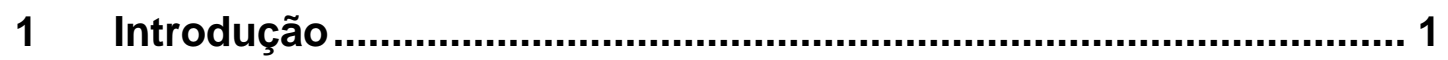

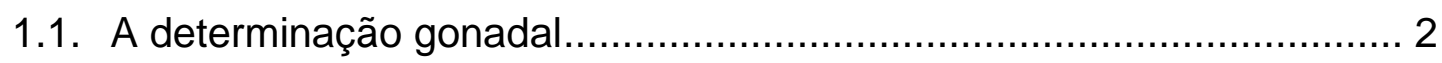

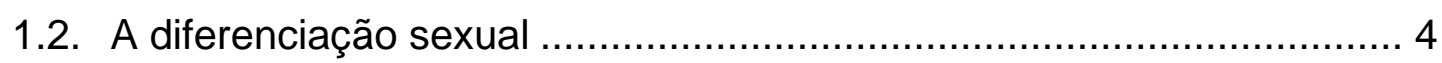

1.3. Os Distúrbios do desenvolvimento gonadal ............................... 5

1.4. Genes e organogênese da gônada indiferenciada .......................... 8

1.5. Genes e organogênese testicular...................................... 18

1.6. Genes e organogênese ovariana ........................................ 21

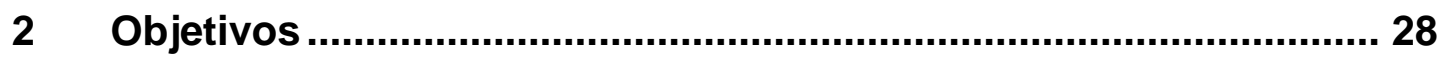

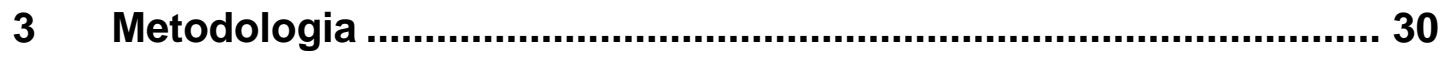

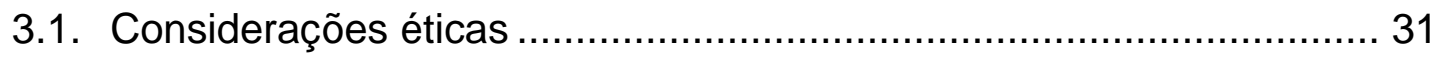

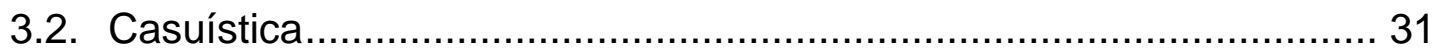

3.3. Avaliação clínica............................................................. 35

3.4. Avaliação por imagem ....................................................... 35

3.5. Avaliação hormonal ................................................................. 36

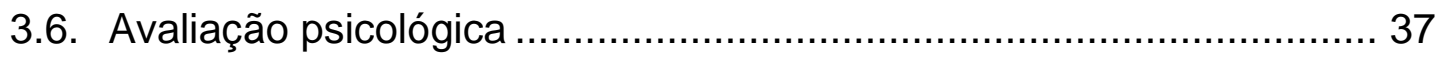




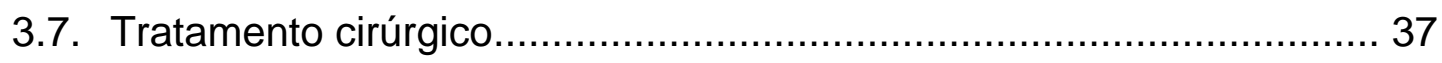

3.8. Avaliação anatomopatológica............................................ 37

3.9. Avaliação citogenética ..................................................... 38

3.10. Avaliação imunológica ............................................................... 38

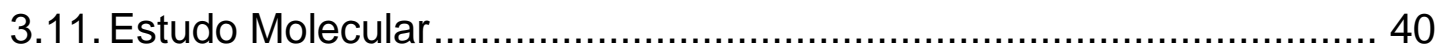

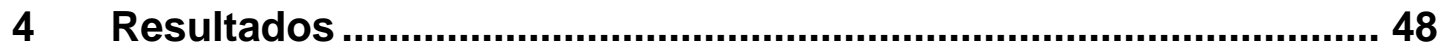

4.1. Grupo I - Pacientes com DDG 46,XY ................................... 49

4.2. Grupo II - Pacientes com DDG 46,XX .................................... 56

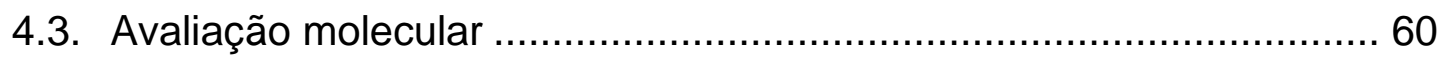

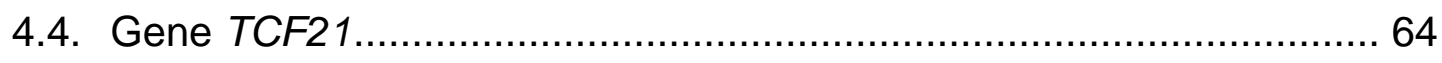

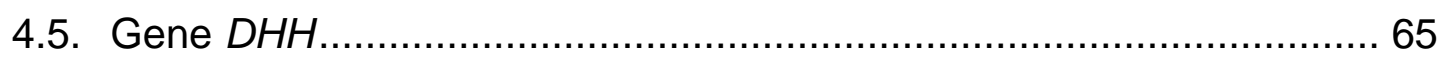

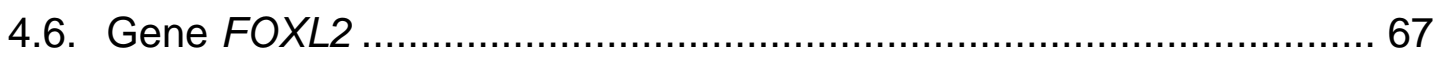

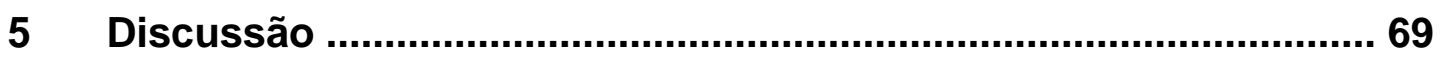

5.1. Grupo I - Pacientes com DDG 46,XY .................................... 70

5.2. Grupo II - Pacientes com DDG 46,XX ................................. 73

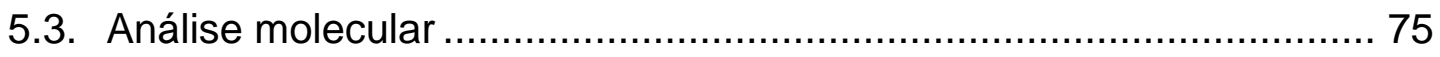

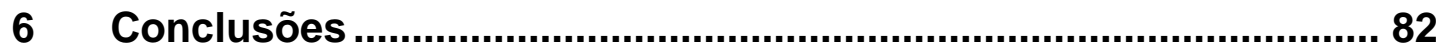

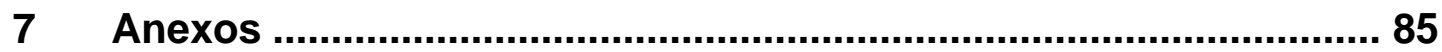

8 Referências ........................................................................... 102 


\section{Lista de Abreviaturas}


Ac

$\mathrm{ACTH}$

$\mathrm{AMH}$

AP

$A R$

ATB7B

ATRX

bHLH

BPES

cDNA

D

DAX1

DDG

DDS

DG

DGC

DGD

DGP

DNA

DNPM

dNTP

DP

dpc

dup

E2

EDTA

EMX2

$\mathrm{F}$

FOG2

FOP

$\mathrm{FSH}$

g.

GATA4

hCG

HMG-box

IFME
Anticorpo

Hormônio adrenocorticotrófico

Hormônio Anti-Mulleriano

Anatomopatológico

Androgen receptor gene

ATPase transporting Beta Polypeptide 7 gene

Alpha-Thalassemia/Mental Retardation X-linked gene basic helix-loop-helix

Síndrome da Blefarofimose-ptose-epicanto inverso

Complementary DNA

Gônada disgenética

Dosage-sensitive sex reversal, adrenal hypoplasia

critical region, on chromosome $X$, gene 1

Distúrbios do desenvolvimento gonadal

Distúrbios do desenvolvimento sexual

Disgenesia gonadal

Disgenesia gonadal completa

Disorders of gonadal development

Disgenesia gonadal parcial

Deoxyribonucleic acid

Desenvolvimento neuropsicomotor

desoxirribonucleotídeo

Desvio padrão

Dias pós coito

Duplicação

Estradiol

Ácido etileno diamonitetracético

Empty spiracles homeobox 2 gene

Feminino

Feminization of Germline 2 gene

Falência ovariana prematura

Hormônio folículo estimulante

Código genético (DNA)

GATA binding protein 4

Hormônio coriogonadotrófico

High mobility group box

Método imunofluorométrico 
Insl3

IVS

LH

M

NT

OMIM

p.

P450scc

$\mathrm{pb}$

PCR

Pod1

RIE

RNA

RNAm

RT

RT-PCR

SDS

SF-1

StCA

$T$

TAE

Taq

TE

TPO

VSX1

WNT4

WT1
Hormônio insulina símile 3

Intron

Hormônio luteinizante

Masculino

Região não traduzida

Online Mendelian Inheritance in Men

Proteína

P450 side chain cleavage

Pares de base

Polymerase chain reaction

podocytes 1 gene

Método radioimunoensaio

Ribonucleic acid

Messenger ribonucleic acid

Reverse transcription

Reverse transcriptase PCR

dodecilsulfato de sódio

Steroidogenic factor 1 gene

Anticorpo anti célula esteroidal

Testosterona

Solução de Tris ácido acético + EDTA

Thermus aquaticus polymerase

Solução de Tris ácido clorídrico + EDTA

Tireoperoxidase

visual system homeobox 1

wingless-type MMTV integration site family, member 4 gene

Wilms tumor 1 gene 


\section{Lista de Símbolos}




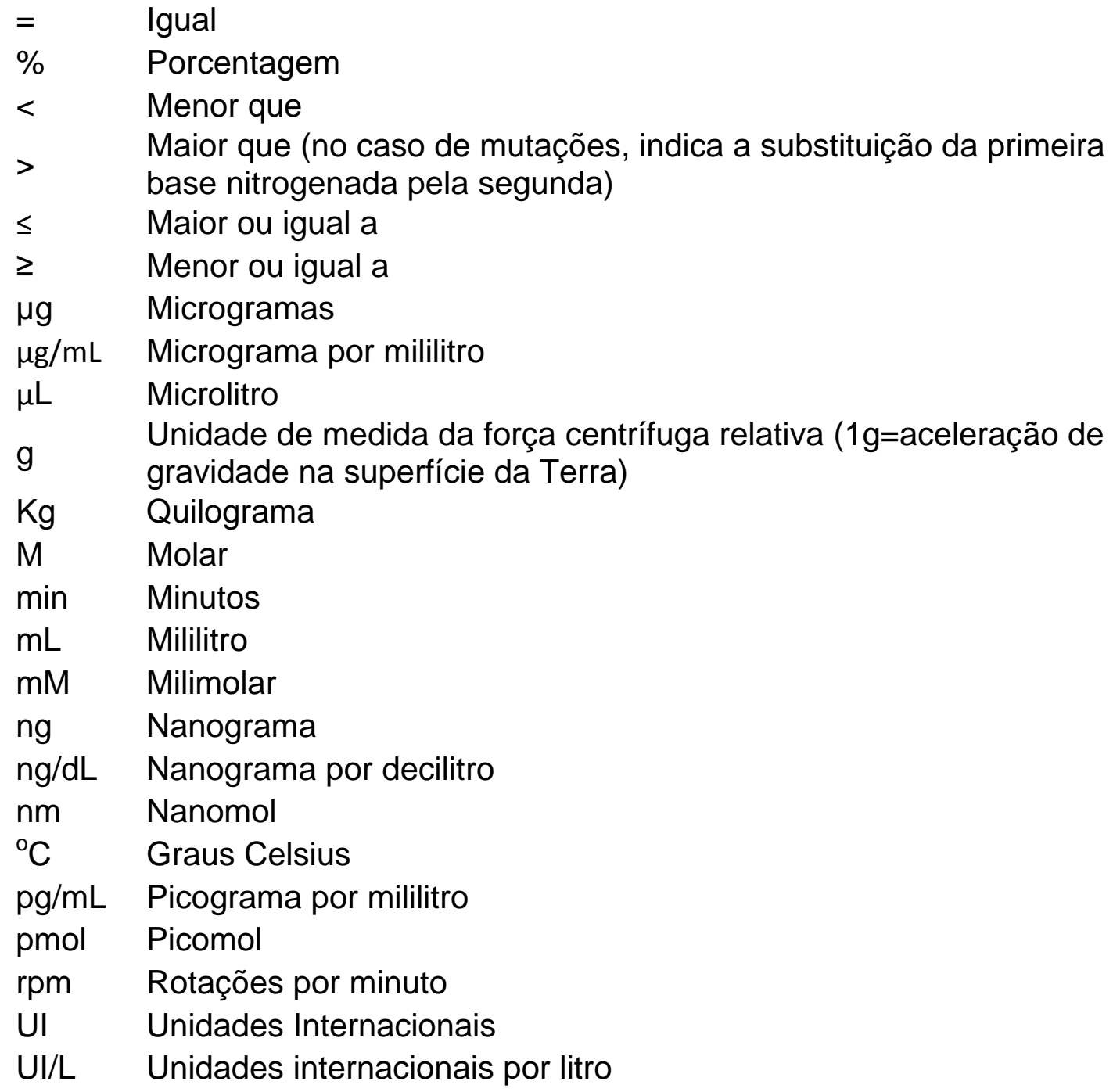


Lista de Figuras 
Figura 1. Genes envolvidos no desenvolvimento gonadal

Figura 2. Gene $C B X 2$ e seus 2 transcritos................................... 12

Figura 3. Gene TCF21 e seus 2 transcritos.. ................................ 16

Figura 4. Gene $D H H$, seus 3 exons e as mutações encontradas.............. 21

Figura 5. Seqüência de aminoácidos da proteína FOXL2 ...................... 26

Figura 6. Gene CBX2 e variantes alélicas encontradas nos pacientes

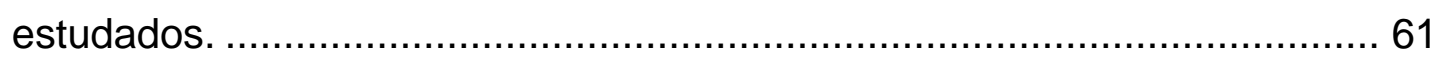

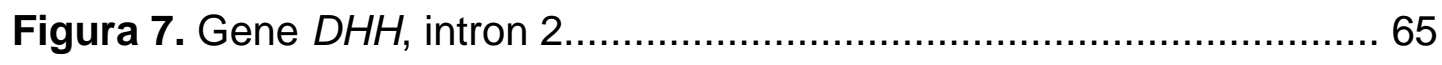

Figura 8. Paciente 58 e suas três variantes. ......................................6 68 
Lista de Tabelas 
Tabela 1- Dados clínicos dos pacientes com DDG 46,XY com disgenesia

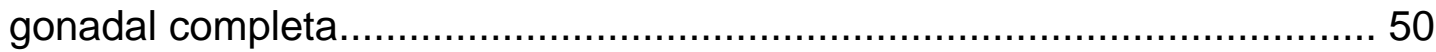

Tabela 2 - Dados clínicos dos pacientes com DDG 46,XY com disgenesia gonadal parcial

Tabela 3 - Dados hormonais dos pacientes com DDG 46,XY portadores de disgenesia gonadal completa.

Tabela 4 - Dados hormonais dos pacientes com DDG 46,XY portadores de disgenesia gonadal parcial

Tabela 5 - Anatomopatológico de pacientes com DG completa 46,XY ..... 54

Tabela 6 - Anatomopatológico de pacientes com DG parcial 46,XY ......... 55

Tabela 7 - Dados clínicos das pacientes com DDG 46,XX ..................... 57

Tabela 8 - Dados hormonais das pacientes com DDG 46,XX ................. 59

Tabela 9 - Variante p.C132R - Alinhamento com outras espécies

Tabela 10 - Classificação dos Distúrbios da Determinação Sexual (alterações do desenvolvimento gonadal)

Tabela 11 - Seqüência dos oligonucleotídeos (primers) utilizados no estudo do gene $C B X 2$

Tabela 12- Seqüência dos oligonucleotídeos (primers) utilizados no estudo do gene TCF21

Tabela 13- Seqüência dos oligonucleotídeos (primers) utilizados no estudo do gene $\mathrm{DH} H$ 
Tabela 14 - Seqüência dos oligonucleotídeos (primers) utilizados no estudo do gene FOXL2

Tabela 15- Seqüência dos oligonucleotídeos (primers) utilizados no estudo do cDNA do gene $\mathrm{DH} H$.

Tabela 16- Seqüência dos oligonucleotídeos (primers) utilizados no estudo do cDNA dos genes $A M H$ e $A R$

Tabela 17 - Dados clínicos e hormonais dos pacientes com disgenesia gonadal completa $46, \mathrm{XY}$

Tabela 18 - Genitais internos e exame anatomopatológico dos pacientes com disgenesia gonadal completa $46, \mathrm{XY}$

Tabela 19 - Dados clínicos e hormonais dos pacientes com disgenesia gonadal parcial $46, \mathrm{XY}$

Tabela 20 - Genitais internos e exame anatomopatológico dos pacientes com disgenesia gonadal parcial $46, \mathrm{XY}$

Tabela 21 - Dados clínicos e hormonais das pacientes com DDG 46, XX.. 98

Tabela 22 - Genitais internos e auto-anticorpos das pacientes com DDG 46, XX 100

Tabela 23 - Variantes alélicas e sua localização no gene CBX2. 101 
Lista de Anexos 
Anexo A - Conferência Internacional sobre o Consenso em Intersexo ...... 86

Anexo B - Tabelas com os oligonucleotídeos e protocolos de PCR dos

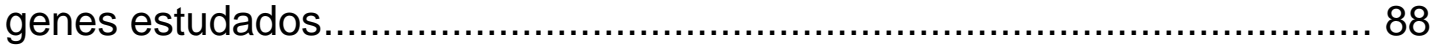

Anexo C - Tabelas com os dados clínicos, hormonais e anatomopatológicos dos pacientes estudados .............................................................. 92

Anexo D - Tabela das variantes alélicas do gene CBX2 ...................... 101 
Resumo 
Gomes CR. Análise clínica e molecular de pacientes com distúrbios do desenvolvimento gonadal [tese]. São Paulo: Faculdade de Medicina, Universidade de São Paulo; 2009. 109p.

Introdução: $O$ termo distúrbios do desenvolvimento gonadal (DDG) inclui condições congênitas nas quais o desenvolvimento gonadal é atípico. Estudos feitos em camundongos observaram que alguns genes como o Cbx2 e o Tcf21 interferem na fase inicial do desenvolvimento gonadal, afetando tanto gônadas $\mathrm{XX}$ quanto $\mathrm{XY}$. O gene $D h h$, por sua vez, codifica o fator de transcrição Dhh, produzido pelas células de Sertoli, que é fundamental para a diferenciação das células de Leydig em gônadas XY. Nos ovários, o gene FOXL2 atua na foliculogênese, sendo fundamental para a formação dos ovários. Objetivos: Analisar clinicamente e pesquisar anormalidades nos genes CBX2, TCF21, DHH e FOXL2 em pacientes portadores de distúrbios do desenvolvimento gonadal $46, X Y$ e $46, X X$. Material e Métodos: Foram estudados 60 pacientes (41 com DDG 46, XY e 19 com DDG 46, XX). A análise molecular foi realizada a partir da amplificação gênica por PCR e sequenciamento direto. Resultados: Várias alterações alélicas foram encontradas nos quatro genes, algumas ainda não descritas na literatura. Uma alteração intrônica no gene $D H H$ foi encontrada em um paciente com DDG 46, XY e não foi encontrada em nenhum dos 360 alelos normais estudados (g.IVS2 +29G>A). Estudamos essa variante através da extração do RNA do testículo do paciente afetado, mas não encontramos alteração no RNA; portanto ela parece não ser uma mutação. No gene TCF21, a variante encontrada foi identificada em controles normais. No gene $C B X 2$, das treze alterações encontradas, uma não foi identificada em 206 alelos normais, e há troca de aminoácidos (p.C132R / g.394 T>C). Trata-se de uma variante que pode ter relação com o fenótipo do paciente, portador de DDG 46, XY. No gene FOXL2, das três alterações encontradas, uma não foi identificada em 206 alelos normais; contudo, não há troca de aminoácidos (p.A181A / g.543 C>T). Conclusão: A apresentação fenotípica dos DDG é bastante variável, e parece ser um espectro clínico de um mesmo distúrbio. Esse estudo sugere que mutações nos genes $C B X 2$, TCF21, FOXL2 e DHH são causas raras de distúrbios do desenvolvimento gonadal.

Descritores: 1.Disgenesia gonadal 46XX; 2.Disgenesia gonadal 46XY; 3.Doenças dos genitais masculinos/genética; 4.Amenorréia; 5.Mutação em linhagem germinativa; 6.Desenvolvimento sexual; 7.Transtornos gonadais; 8.Infantilismo sexual 
Summary 
Gomes CR. Clinical and molecular analysis of patients with disorders of gonadal development [thesis]. São Paulo: "Faculdade de Medicina, Universidade de São Paulo"; 2009. 109p.

Introduction: Congenital disorders of gonadal development (DGD) include conditions whose gonadal development is atypical. Studies in mice found that some genes such as $C b \times 2$ and Tcf21 interfere in the initial phase of gonadal development, affecting both $X X$ and $X Y$ gonads. Dhh gene, in turn, encodes the transcription factor Dhh, produced by Sertoli cells, which is essential for the differentiation of Leydig cells in XY gonads. In the ovaries, genes as FOXL2 act in folliculogenesis, fundamental to the development of the ovaries. Objectives: To analyze patients with disorders of gonadal development (DGD) 46, XY and 46, XX and research mutations in $C B X 2$, TCF21, DHH and FOXL2 genes. Methods: We analyzed 60 patients (41 DGD 46, XY patients and 19 DGD 46, XX patients). The whole coding region of CBX2, TCF21, DHH and FOXL2 genes were amplified by PCR and direct sequenced. Results: Several allelic variations have been found in the four genes, some not even described by literature. One intronic variation in $\mathrm{DHH}$ was described in one patient with 46, XY DGD and it wasn't found in any of the 360 normal control alleles studied (g.IVS2 +29G>A). We studied this variant through RNA extraction from the affected patient's testes, but we didn't find any alteration in the RNA, so it doesn't seem to be a mutation. In TCF21 gene, the single variant that was found was identified in normal controls. In CBX2 gene, among the 13 alterations described, one wasn't identified in 206 normal control alleles, and there is amino acid change (p.C132R / g.394 T>C). This is a variant that may be a mutation, causing the patient's phenotype that had 46, XY DGD. In FOXL2, among the 3 variations described, one wasn't indentified in 206 normal control alleles, but there wasn't amino acid change (p.A181A / g.543 C>T).Conclusion: The phenotypic presentation of DGD is highly variable, and it seems to be a clinical spectrum of the same disorder. This study suggests that mutations in CBX2, TCF21, FOXL2 and DHH genes are rarely causes of disorders of gonadal development.

Descriptors: 1.Gonadal dysgenesis 46XX; 2.Gonadal dysgenesis 46XY; 3.Genital diseases, male/genetics; 4.Amenorrhea; 5.Germ-line mutation; 6.Sexual development; 7.Gonadal disorders; 8.Sexual infantilism 
1 Introdução 
A diferenciação sexual em mamíferos é um complexo processo que se inicia com o estabelecimento do sexo genético $(X X$ ou $X Y)$ na fertilização e depende da interação de genes, fatores transcricionais, hormônios e receptores hormonais para que se complete normalmente. A definição do sexo genético determina, em linhas gerais, o caminho que deve seguir a formação da gônada, que inicialmente apresenta as mesmas características histológicas tanto nos machos quanto nas fêmeas e é, portanto, definida como indiferenciada ou bipotente.

\subsection{A determinação gonadal}

A formação e o desenvolvimento das gônadas nos mamíferos são caracterizados pelo surgimento da gônada bipotente nos mesonefros, fazendo parte da crista urogenital (que irá contribuir com linhagens celulares para o córtex adrenal, gônadas e rins) $)^{1}$. Aproximadamente no $10^{\circ}$ dia pós coito (dpc), em camundongos, ocorre a proliferação do mesotélio (epitélio celômico) em uma área restrita da face médio lateral dos mesonefros, dando origem a uma pequena gônada ${ }^{2}$. Ao mesmo tempo, células germinativas estão completando sua migração da base do alantóide ao longo do tubo digestivo, e através dos mesonefros até o local onde a gônada está se formando. A partir daí, com todas as linhagens celulares constituintes da 
gônada presentes, inicia-se o processo de diferenciação, que irá determinar se a gônada será um testículo ou um ovário.

Entre as células somáticas na gônada primitiva, as células de sustentação são as primeiras a se diferenciarem em células foliculares (da granulosa) nas gônadas $X X$ ou em células de Sertoli nas gônadas $X Y^{3}$. $O$ destino dos outros tipos celulares como as células esteroidogênicas (células da Teca em XX e células de Leydig em XY) depende dessa diferenciação das células de sustentação.

A diferenciação das células germinativas também parece depender desse ambiente criado pelas células de sustentação específicas do ovário ou do testículo, e não do seu sexo genético ${ }^{1}$. As células germinativas demonstram seu destino quando entram em meiose entre 12,5 e 13,5 dpc na gônada XX ou quando param na mitose na gônada XY. A entrada na meiose parece depender da atividade do ácido retinóico. Nos testículos, o ácido retinóico é degradado pela enzima codificada pelo gene Cyp26B1, expresso especificamente em machos ${ }^{1}$.

O desenvolvimento dos testículos e a diferenciação de suas células de sustentação não dependem das células germinativas ${ }^{4}$. Evidências morfológicas sugerem que a diferenciação inicial das células das gônadas XX também não depende da presença de células germinativas ${ }^{5}$. No entanto, estas são necessárias para a formação e manutenção dos folículos ovarianos na vida pós-natal, e a perda de células germinativas no ovário resulta na degeneração da estrutura ovariana ${ }^{1}$. 
O processo de determinação gonadal ocorre precocemente no embrião estando definido até a $11^{\underline{a}}$ semana de gestação em humanos. A etapa que se segue, denominada diferenciação sexual, compreende todos os eventos subseqüentes à organogênese gonadal, na qual a diferenciação da genitália interna e externa ocorrerá secundariamente à ação dos hormônios secretados pela gônada fetal ${ }^{6}$.

\subsection{A diferenciação sexual}

A genitália interna origina-se de ductos pareados que inicialmente são indistinguíveis nos embriões $\mathrm{XX}$ e $\mathrm{XY}$ : os ductos Mullerianos (paramesonéfricos) e os ductos Wolffianos (mesonéfricos) ${ }^{7}$. Os testículos produzem (dentre outras substâncias) três diferentes hormônios que são essenciais para o desenvolvimento masculino. O primeiro deles é o Hormônio Anti-Mulleriano $(\mathrm{AMH})$, que é produzido primariamente pelas células de Sertoli, e causa a regressão dos ductos Mullerianos que iriam originar as trompas, útero e terço superior da vagina. Em seguida, as células de Leydig produzem testosterona, que induz a diferenciação dos ductos de Wolff em vesículas seminais, epidídimos e ductos deferentes. Finalmente, no fim da gestação, as células de Leydig produzem o peptídeo insulina-símile 3 (Insl3), que causa a descida dos testículos para a sua posição característica até o escroto. $\mathrm{Na}$ ausência desses três hormônios, os ductos Mullerianos se desenvolvem originando as estruturas da genitália interna feminina e os ductos de Wolff regridem, além de não haver a descida das gônadas até o escroto. 


\subsection{Os Distúrbios do desenvolvimento gonadal}

O termo distúrbios do desenvolvimento gonadal (DDG) inclui condições congênitas nas quais o desenvolvimento gonadal é atípico, e é caracterizado pela presença de ambigüidade genital e/ou reversão sexual em indivíduos 46,XY e pela ausência de caracteres sexuais secundários e/ou infertilidade em indivíduos 46,XX. A classificação e nomenclatura dos pacientes com DDG foi revista em 2006, a partir de um consenso realizado pela Sociedade Européia de Endocrinologia Pediátrica e pela Sociedade de Endocrinologia Pediátrica Americana (Lawson Wilkins), em colaboração com os participantes da Conferência Internacional do Consenso em Intersexo ${ }^{8}$ (Anexo A). Abaixo, detalharemos cada um dos DDG.

\subsubsection{Agenesia gonadal}

É caracterizada pela ausência total de tecido gonadal em indivíduos $X X$ e $X Y^{9}$. Clinicamente, por não haver formação da gônada (ou sua regressão muito precoce) os indivíduos $X Y$ apresentam-se com a genitália externa totalmente feminina, presença de derivados Mullerianos e ausência de derivados Wolffianos (genitália interna também feminina). Nos indivíduos XX, a característica clínica principal é a ausência de desenvolvimento puberal (telarca e menarca). Como não há genitália ambígua, os pacientes afetados geralmente procuram cuidados médicos na puberdade, quando não há desenvolvimento puberal. 


\subsubsection{Disgenesia gonadal completa e parcial}

Disgenesia gonadal consiste em uma variedade de condições clínicas na qual o desenvolvimento gonadal é anormal e pode ser encontrado na forma completa e parcial ${ }^{9}$. A forma completa é caracterizada nos indivíduos XY e XX pela presença de genitália externa e interna femininas, ausência de caracteres sexuais secundários, estatura normal ou alta sem estigmas da síndrome de Turner e presença de gônadas disgenéticas bilaterais ou gônadas em fita. A forma parcial em pacientes $X Y$ é caracterizada pelo desenvolvimento parcial dos testículos, que resulta na presença de genitália externa e interna ambíguas, que podem variar o grau de ambigüidade dependendo do quanto a função testicular foi preservada.

Nos indivíduos $\mathrm{XX}, \mathrm{O}$ desenvolvimento ovariano pode ser interrompido desde sua formação, com uma completa falência na formação dos folículos ovarianos, até uma redução no número desses folículos (intra-útero ou após o nascimento), resultando, no primeiro caso, na falta de desenvolvimento de caracteres sexuais secundários e amenorréia primária, e no segundo caso, em amenorréia secundária (ou dependendo do grau da redução do número de folículos, em amenorréia primaria e ausência de desenvolvimento sexual secundário também). Todo esse grupo de indivíduos $X X$ cuja formação ovariana foi interrompida apresenta o que denominamos de falência ovariana prematura ${ }^{10}$. A falência ovariana prematura clinicamente é definida, portanto, como um distúrbio onde as mulheres apresentam amenorréia 
antes dos 40 anos, seja primária ou secundária, associada a elevadas concentrações de gonadotrofinas séricas e baixas concentrações dథ 17 estradiol. Dentre as causas de falência ovariana prematura estão as anomalias do cromossomo X (como síndrome de Turner), síndrome do X frágil, disgenesia gonadal (DG) e ooforite auto-imune ${ }^{11,12}$. Ela também pode estar associada a quadros sindrômicos associados a genes autossômicos recessivos, como é o caso da síndrome de Perrault, cujas características principais são disgenesia gonadal e perda auditiva neurossensorial (ainda não identificado 0 gene responsável ${ }^{13}$ ). A disgenesia gonadal denominada pura, por sua vez, classicamente é definida como um distúrbio caracterizado por apresentar cariótipo 46,XX, ausência de caracteres sexuais secundários, gonadotrofinas séricas elevadas e gônadas em fita bilaterais, apesar de que alguns autores consideram alguns pacientes com amenorréia secundária também portadores de disgenesia gonadal.

\subsubsection{Síndrome da regressão testicular embrionária}

Essa síndrome tem sido considerada parte do espectro clínico da disgenesia gonadal parcial $^{14}$. A maioria dos pacientes apresenta genitália ambígua ou micropênis importante, associado à regressão testicular em um ou ambos os lados. 


\subsubsection{Disgenesia gonadal associada a um quadro sindrômico}

Várias síndromes associadas a disgenesia gonadal em humanos já foram descritas e associadas a mutações em genes específicos ${ }^{9}$. Assim, mutações no WT1 foram descritas em pacientes com síndrome de WAGR, caracterizada pela presença de tumor de Wilm's, aniridia, anomalias genitourinárias e retardo mental. Ainda associadas ao WT1 foram descritas as síndromes de Denys-Drash e de Frasier, que estão associadas a alterações renais e a tumores renais e/ou gonadais. Mutações no SF1 foram descritas em pacientes com alterações gonadais associadas ou não à insuficiência adrenal; disgenesia gonadal associada à displasia campomélica têm sido associadas a mutações no $S O X 9$, e outras síndromes mais raras têm sido associadas a mutações em outros genes, como DMRT1, DMRT2, ATRX, e à superexpressão de alguns genes, como o DAX1 e o WNT4.

\subsection{Genes e organogênese da gônada indiferenciada}

Uma complexa cascata onde participam genes localizados nos cromossomos sexuais e em autossomos tem sido implicada nos processos de determinação e diferenciação sexual (Figura 1). Os genes envolvidos nesses processos desempenham seus papéis em vários estágios da diferenciação sexual, alguns agem de forma combinada com outros genes e um pequeno número deles tem um papel crítico num momento específico e depois deixam de agir. 
Embora a expressão de um grande número de genes tenha sido demonstrada na gônada fetal, o papel de cada um deles no processo de determinação gonadal não está completamente definido.

A organização da prega urogenital durante a embriogênese é controlada por diversos genes que agem em sincronia. A análise do padrão temporal e topográfico da expressão dos genes WT1 e SF1 sugere um papel importante desses genes na preparação da gônada para a determinação sexual ${ }^{15,16}$. O WT1 parece estar envolvido na expressão do SRY na gônada e na descida testicular ${ }^{17}$ e age a montante dos genes SF1 e DAX1 ${ }^{18}$. O SF1 parece preparar o ambiente para a expressão do SRY e age também auxiliando a expressão do $A M H$ (gene que codifica a produção do hormônio anti-mülleriano), que é o primeiro marcador da diferenciação testicular. Posteriormente, na diferenciação sexual, o gene SF1 regula a produção de esteróides pela célula de Leydig, cujo desenvolvimento adequado depende do estabelecimento prévio da linhagem de Sertoli.

Outros genes que afetam primariamente a diferenciação gonadal masculina foram descritos em modelos de camundongos knockout; dentre eles, o M33, o Lhx9, o Pod1 e o Dmtr1. O gene M33 (polycomb homologue) parece estar envolvido na remodelação da cromatina, mas seu exato papel na diferenciação gonadal é desconhecido ${ }^{19}$. O seu homólogo humano foi recentemente isolado e designado CBX2 (Chromobox Homolog 2, Drosophila Polycomb Class). O fator de transcrição Lhx9 (Lim homeobox) é necessário para a expressão completa do $S f 1{ }^{18,20}$. Até o momento nenhuma mutação foi descrita no $L h x 9$ em pacientes $X Y$ com reversão 
sexual ${ }^{21}$. No entanto, camundongos knockout no $L h x 9$ ou no M33 não apresentam desenvolvimento gonadal ${ }^{19,20}$. Pod1 é um fator de transcrição relacionado à diferenciação de células glomerulares viscerais epiteliais (podócitos) em rins e pulmões ${ }^{22}$. Em camundongos com ausência deste fator, as gônadas de ambos os sexos são hipoplásicas e nas gônadas masculinas a vascularização está comprometida devido à formação defeituosa do vaso celômico e à migração reduzida de células endoteliais dos mesonéfrons ${ }^{23}$. O gene codificador deste fator é o Tcf21 (Transcription Factor 21), já isolado em humanos, porém ainda não estudado em pacientes com alterações do desenvolvimento gonadal ${ }^{24}$.

A Figura 1 faz uma demonstração temporal dos genes conhecidos que participam do desenvolvimento gonadal a partir da crista urogenital.

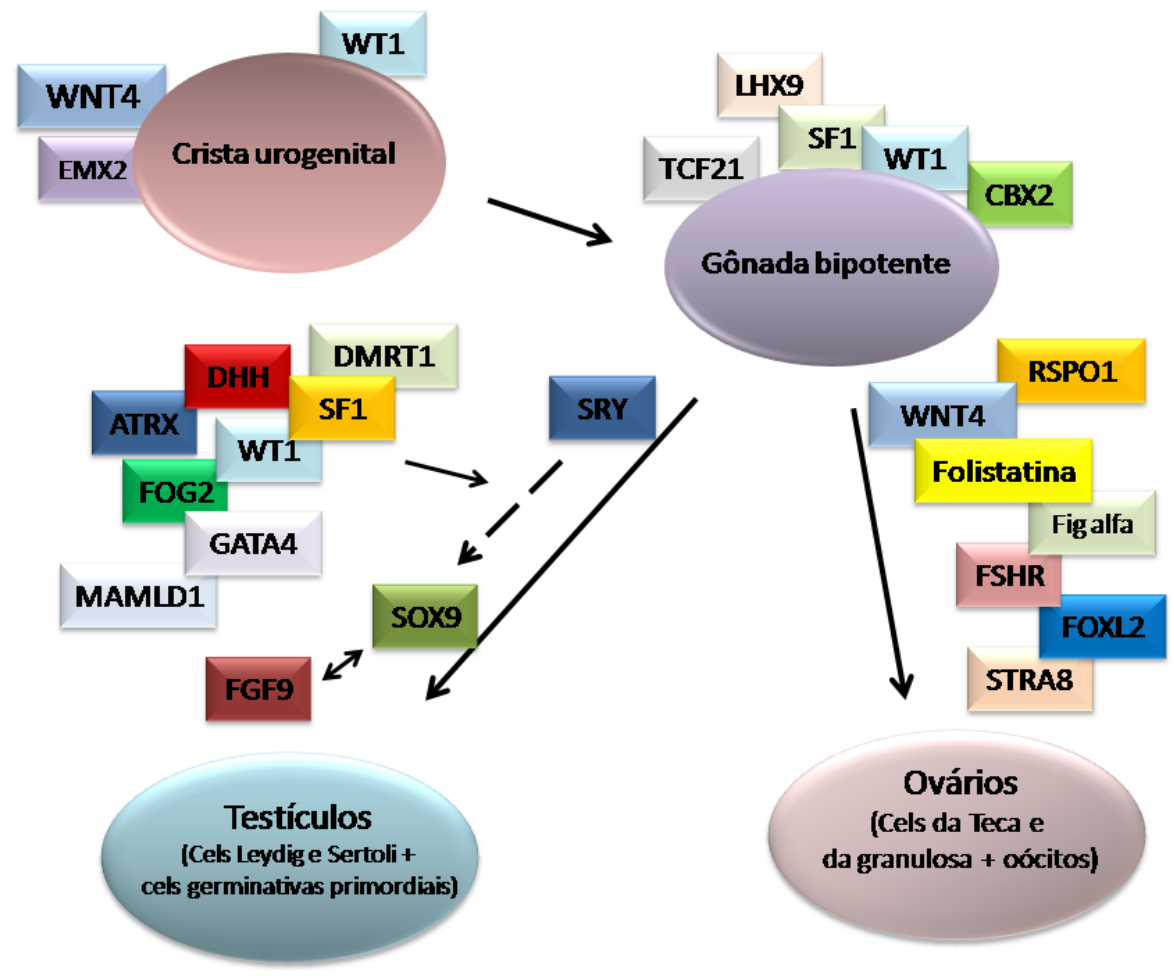

Figura 1. Genes envolvidos no desenvolvimento gonadal 
O Dmrt1 é outro gene que codifica o fator de transcrição Dmrt1 (doublesex-and mab-related), e cuja deleção origina testículos dismórficos em camundongos ${ }^{25}$.

Alguns genes, a seguir, serão descritos com mais detalhes, devido à importância dos mesmos em nosso estudo.

\subsubsection{Gene $C B X 2$}

O gene CBX2 (Polycomb-like Chromobox Gene) pertence ao grupo de genes que codificam proteínas com um chromodomain. A presença de um grupo de proteínas de cromatinas encontradas em drosófilas com função de suprimir sua diversificação e com um domínio altamente conservado de 40 aminoácidos levou à denominação desse último de chromodomain (por ser modificador da organização da cromatina). A região do DNA que codifica o chromodomain é denominada "chromobox". Dentro desse grupo de proteínas, uma em particular é denominada Polycomb.

Os genes Polycomb em drosófilas atuam como supressores de genes responsáveis pela homeostase e por outros genes que atuam no desenvolvimento do animal. Em mamíferos, esse tipo de proteína poderia ter papel em dois fenômenos: inativação do cromossomo X e imprinting genético 26. Isto sugere que mutações nesses genes poderiam interferir no programa morfogenético embrionário, ou ainda atuar em supressão de neoplasias ${ }^{27,} 28$. Seu análogo em camundongos, M33, foi isolado em 1992 por Pearce e colaboradores $^{29}$, a partir da semelhança de seu chromodomain. 
Em 1995, Josef Gecz e colaboradores ${ }^{26}$ descreveram o CBX2 como um gene encontrado no cromossomo 17q25 em humanos. Ele apresenta 2 transcritos, que não codificam uma mesma proteína, conforme web site Ensembl Genome Browser ${ }^{30}$. O primeiro é codificado por quatro exons e apresenta 211 aminoácidos; o segundo, mais semelhante à proteína do camundongo, é codificado por cinco exons e possui 532 aminoácidos. O transcrito com quatro exons apresenta 4339 pares de base e seus exons possuem, em ordem crescente, 114, 44, 66 e 837 pares de base, sendo que o primeiro e último exons apresentam regiões não codificadoras (de 42 e 383 pares de base, respectivamente). O transcrito com cinco exons apresenta 9387 pares de base, e seus exons possuem, em ordem crescente, 114, 44, 66, 106 e 3848 pares de base, sendo que o primeiro e o último exons também apresentam regiões não codificadoras (de 42 e 2537 pares de base, respectivamente) (Figura 2).

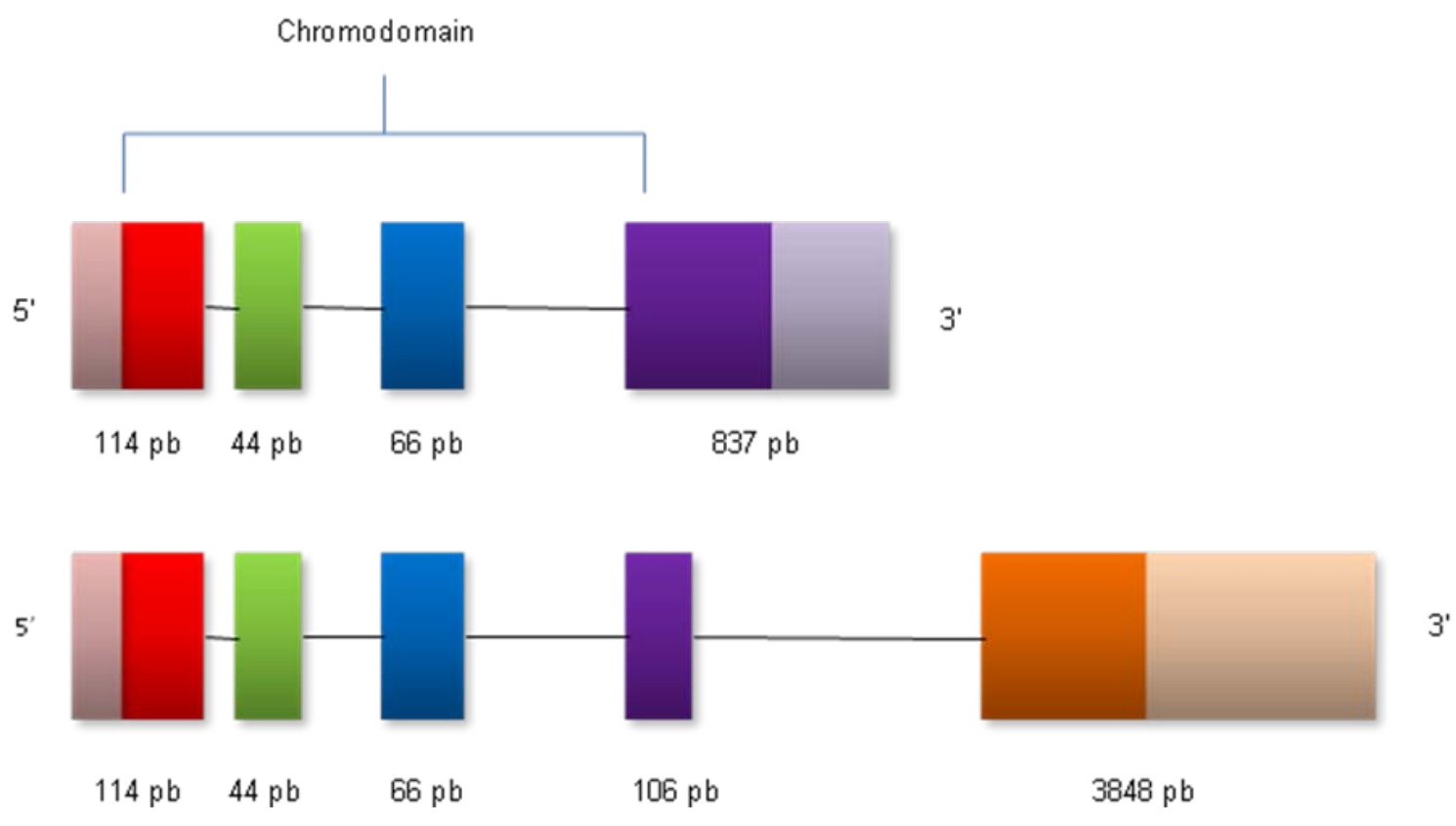

Figura 2. Gene $C B X 2$ e seus 2 transcritos. Acima, transcrito 1 com 4 exons; abaixo, transcrito 2, com 5 exons. Em destaque, a região do gene que codifica o "chromodomain". pb: pares de base 
Em 1998, Kato-Fukui e colaboradores ${ }^{19}$ produziram camundongos transgênicos com o gene M33 corrompido através da inserção de um vetor em seu quinto exon. Mais da metade desses camundongos modificados morreram, e os sobreviventes apresentavam alteração no sistema reprodutivo. Defeitos no crescimento gonadal surgiram no período próximo à expressão do Sry, sugerindo que a ausência do M33 tenha causado alteração no desenvolvimento gonadal em etapas a montante desse gene. A maioria dos camundongos $X Y$ apresentava genitália externa alterada: $30 \%$ apresentavam genitália externa feminina com clitóris e orifício vaginal; 50\% tinham genitália ambígua com clitóris, mas sem orifício vaginal, e 20\% apresentavam genitália externa masculina com pênis, mas eram estéreis. Em relação às gônadas e genitália interna, nenhum dos camundongos apresentava testículos bilaterais; 50\% apresentavam útero, trompas e ovários contendo folículos, 25\% apresentavam útero, trompas e gônadas indeterminadas, e os 25\% restantes apresentavam testículos e ovários. Nos camundongos XX também foram encontradas anomalias no sistema reprodutivo. Em 14 dos 16 animais os ovários eram hipoplásicos, e nos dois animais restantes não foram encontradas gônadas. Nos ovários encontrados, a presença de folículos era diminuída, e todos os animais eram estéreis. Os embriões dos camundongos transgênicos não apresentaram atraso no desenvolvimento somático antes do nascimento, embora a gonadogênese tenha sido retardada.

Esse estudo sugere que o gene M33 deve regular outros genes necessários ao desenvolvimento gonadal precoce, e que o retardo no 
desenvolvimento da gônada (causado pelo knockout do gene) possa desregular estes genes que atuam a montante do Sry.

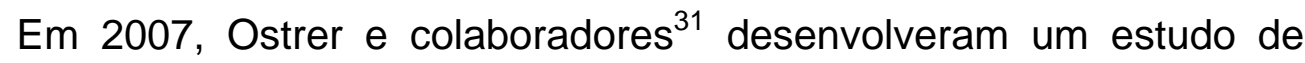
expressão gênica em testículos humanos, onde foi observada a expressão do CBX2 em citoplasma de células testiculares com sete semanas de idade gestacional, bem como dos genes EMX2, GATA4 e FOG2. Depois de sete semanas, foi observada expressão de todos esses genes em vários outros tipos celulares ${ }^{31}$. Isto confirma a importância do CBX2 para o desenvolvimento gonadal, uma vez que ele surge antes da expressão do SRY e da diferenciação das células de Sertoli e de Leydig.

Finalmente, em 2009, Biason-Lauber e colaboradores descreveram uma paciente portadora de um distúrbio do desenvolvimento gonadal 46,XY, apresentando genitália externa e interna totalmente femininas, inclusive com ovários histologicamente normais ${ }^{32}$. Esta paciente apresentava mutação em heterozigose composta do gene CBX2 (p.P98L e p.R443P), e o estudo funcional das mutações descritas sugeriu que o gene $C B X 2$ apresenta um papel no desenvolvimento gonadal à montante do gene $S R Y$ a partir do estímulo da expressão de genes específicos, como o SF-1.

Diante dos estudos em animais e desses dois estudos recentes em seres humanos vemos a importância de se aprofundar o estudo de seu análogo em humanos com distúrbios do desenvolvimento gonadal. 


\subsubsection{Gene TCF21}

Proteínas básicas hélice alça hélice (basic helix-loop-helix - bHLH) são proteínas de regulação transcricional que atuam na determinação do destino celular e diferenciação tecidual em embriões. Proteínas bHLH contêm um domínio conservado de 50 aminoácidos que consiste em duas alfa hélices separadas por uma alça variável, adjacente a uma seqüência que é altamente enriquecida por aminoácidos básicos. A região HLH interfere na dimerização protéica, enquanto que a região básica atua em ligações DNA específicas. Algumas proteínas bHLH interferem na diferenciação de tecido gonadal. Um exemplo disso é a proteína Figla, codificada pelo gene FIG alpha em mamíferos, que é necessário para a formação dos folículos primordiais no ovário desses animais ${ }^{33}$.

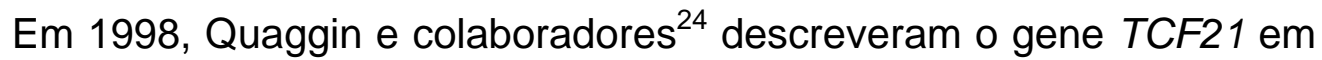
humanos e camundongos. Eles denominaram a proteína codificada de POD1 por esta ser altamente expressa em podócitos (células epiteliais glomerulares renais). A proteína humana de 179 aminoácidos contém um domínio bHLH de 57 aminoácidos, um sinal de localização nuclear e um domínio de ativação transcricional ácido.

O gene TCF21 está localizado no cromossomo 6q23-24, e possui dois transcritos, que traduzem uma mesma proteína (conforme web site Ensembl Genome Browser ${ }^{30}$ ). O transcrito 1 apresenta 2 exons e 6416 pares de base, tendo o primeiro exon 710 pares de base (os 260 primeiros pares de base 
não são codificadores) e o segundo exon 3841 pares de base (os últimos 3751 pares de base não são codificadores). O transcrito número 2 possui três exons, tendo o primeiro 513 pares de base, o segundo 98 pares de base e o terceiro 2383 pares de base, sendo que os 63 primeiros pares de base do primeiro exon, os 8 últimos pares de base do segundo exon e todo o terceiro exon não são codificadores (conforme web site Ensembl Genome Browser $^{30}$ ) (Figura 3).

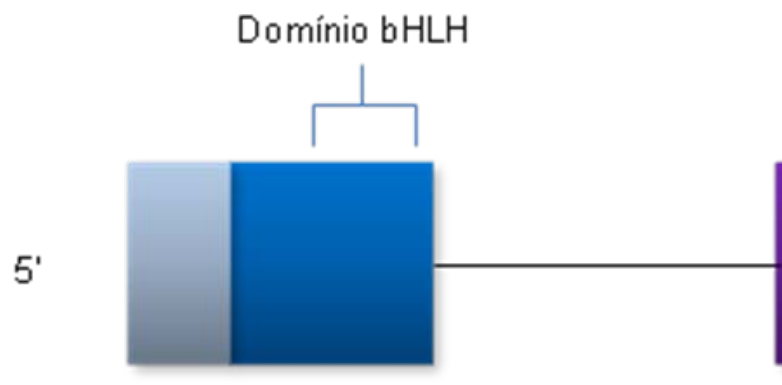

$710 \mathrm{pb}$

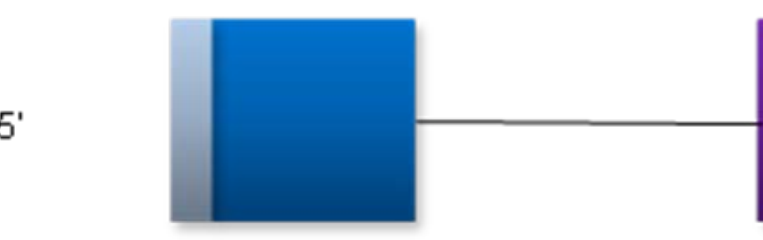

$513 \mathrm{pb}$

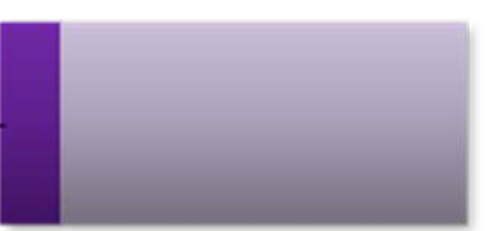

$3^{\prime}$

$3841 \mathrm{pb}$

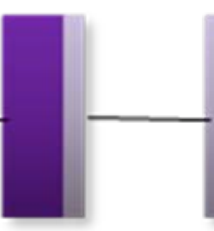

$98 \mathrm{pb}$

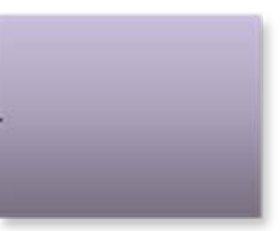

$2383 \mathrm{pb}$

Figura 3. Gene TCF21 e seus 2 transcritos. Acima, transcrito 1 com 2 exons; abaixo, transcrito 2, com 3 exons. Em destaque, a região do gene que codifica o domínio "bHLH". pb: pares de base

Em 2004, Cui e colaboradores $^{23}$ descreveram o estudo de camundongos knockout do gene Tcf21, onde foram observadas alterações no desenvolvimento gonadal de animais $\mathrm{XY}$ e $\mathrm{XX}$. Todos os camundongos XY apresentavam genitália externa feminina, e os testículos eram hipoplásicos, com forma irregular e permaneceram adjacente aos rins, freqüentemente conectados diretamente à adrenal. Nos camundongos $X X$, 
os ovários também se localizavam adjacentes aos rins, sendo o ovário esquerdo também diretamente conectado à adrenal. Eles, por sua vez, não eram hipoplásicos, mas apresentavam forma irregular. Observaram, ainda, que as gônadas, neste estágio, eram indistinguíveis macroscopicamente.

A análise histológica dos testículos observou a falta de organização dos cordões testiculares e revelou inúmeras células com características sugestivas de apoptose. Nos ovários, apesar das células germinativas apresentarem-se em meiose (prófase) nos animais selvagens, nos camundongos knockout estas células encontravam-se mais semelhantes àquelas presentes em testículos. Também nos ovários, o número de células em apoptose foi consideravelmente importante.

O estudo também demonstrou que a ausência da proteína Pod1 aumenta (indiretamente) a expressão, e de forma ectópica, do gene Sf-1. Apesar disso, nenhum camundongo mutante $X X$ ou $X Y$ sofreu virilização da genitália interna ou externa, e os testículos não desceram para o local esperado. É sugerido, portanto, que uma regulação precisa do Sf-1 é necessária para o desenvolvimento gonadal normal.

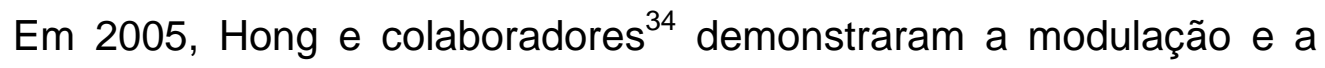
transativação do receptor de andrógeno $(A R)$ pela proteína Pod-1. Eles observaram (a partir de células de Sertoli de camundongos transfectadas por plasmídeo de coexpressão Pod-1 / gene reporter luciferase na região promotora do receptor androgênico) que o Pod-1 inibe a atividade do promotor do $A R$ em até cinco vezes, diminuindo a expressão do gene. Observaram também que Pod-1 inibe a transativação do receptor androgênico. 
Estes estudos reforçam a importância do gene TCF21 para o desenvolvimento de ovários e testículos em estágios precoces, e em especial no desenvolvimento e funcionamento dos testículos, em um estágio posterior. Diante desses resultados, vimos a necessidade de estudar com mais detalhes esse gene em pacientes com distúrbios do desenvolvimento gonadal.

\subsection{Genes e organogênese testicular}

Com o refinamento de técnicas de análise cromossômica, acumularam-se evidências da existência de uma regulação da organogênese testicular pelo cromossomo Y em mamíferos.

\subsubsection{Gene SRY}

A identificação do gene SRY (Sex-determining Region-Y chromosome) no braço curto do cromossomo $\mathrm{Y}$ (Yp11.3), próximo a região pseudoautossômica, no início da década de 90 permitiu o esclarecimento de uma importante etapa no processo de determinação da gônada embrionária masculina $^{35}$.

Em humanos, o SRY se expressa precocemente na gônada masculina, sendo encontrado nos cordões sexuais que dão origem às células de Sertoli e nas células germinativas adultas. O SRY é considerado essencial como iniciador do desenvolvimento testicular a partir da 
diferenciação da gônada bipotencial no sentido testicular ${ }^{36}$. Esta função é alcançada pela transformação dos precursores das células de suporte em células de Sertoli. O subseqüente desenvolvimento sexual masculino das células testiculares é direcionado pelo efeito destas células. Na vizinhança das células de Sertoli os precursores das células esteroídicas desenvolvemse em células de Leydig e as células germinativas em espermatogônias ${ }^{37}$.

No entanto, apesar do clássico experimento de $\mathrm{Koopman}^{38}$ ter identificado o gene SRY como o fator determinante testicular, parece não existir uma relação simples de causa-efeito entre o gene SRY e o desenvolvimento gonadal masculino em vários pacientes com sexo reverso. Assim, o gene SRY não é identificado na maior parte dos pacientes com distúrbio do desenvolvimento sexual (DDS) ovotesticular (anteriormente denominados hermafroditas verdadeiros), bem como nos DDS testicular (anteriormente denominados homens $\mathrm{XX}$ ) com ambigüidade genital, apesar do desenvolvimento testicular nestes pacientes. ${ }^{39}$. Por outro lado, as mutações na seqüência do gene $S R Y$ são identificadas em apenas 15\% dos pacientes com disgenesia gonadal 46, $X Y^{40,41}$. A maioria destas mutações é encontrada no domínio $H M G$-box, responsável pela ligação ao $D N A^{42}$ e o fato desta região ser a única porção do SRY altamente conservada entre as espécies, sugere ser esse o único domínio essencial para ação do SRY. No entanto, um reduzido número de casos é relatado na literatura associando mutações no $S R Y$ fora deste domínio e causando comprometimento gonadal ${ }^{43}$.

Portanto, a participação do gene SRY na etiologia dos distúrbios do desenvolvimento gonadal é menos freqüente do que se poderia supor 
inicialmente, visto seu papel fundamental na determinação testicular. Nas inter-relações dos genes da cascata do desenvolvimento sexual, uma função proposta para o gene SRY seria a de ativar a transcrição de genes à jusante na cascata que levariam ao desenvolvimento masculino ${ }^{7}$. Estas observações confirmam o envolvimento de outros genes no processo do desenvolvimento gonadal.

\subsubsection{Gene $D H H$}

Atualmente sabe-se que a diferenciação das células de Leydig fetais depende da sinalização parácrina da proteína extracelular Desert Hedgehog, que é secretada pelas células de Sertoli ${ }^{44}$. Essa proteína é codificada pelo gene $D H H$, um membro da família hedgehog de proteínas sinalizadoras, assim como outras proteínas como Sonic hedgehog e Indian hedgehog. Esse gene está localizado no cromossomo 12q13.1, é composto por três exons e codifica uma proteína de 396 aminoácidos. Seu primeiro exon possui 610 pares de base (pb), o segundo 262 pb e o terceiro 1060 pb (conforme web site Ensembl Genome Browser ${ }^{30}$ ).

Mutações no $\mathrm{DHH}$ foram encontradas em 3 pacientes com disgenesia gonadal completa $X Y^{45}$ e em um paciente com disgenesia gonadal parcial $X Y$ associada a neuropatia minifascicular ${ }^{46}$ (Figura 4). Foi demonstrado em camundongos que a diferenciação dos miócitos peritubulares e conseqüente formação do cordão testicular é regulada pelo $D h h^{47}$. Além disso, foi sugerido que a sinalização do Dhh (em associação 
ao Ptch1, seu receptor) é um regulador positivo na diferenciação das células de Leydig produtoras de esteróides nos testículos fetais (via regulação positiva do Sf1) ${ }^{44}$.

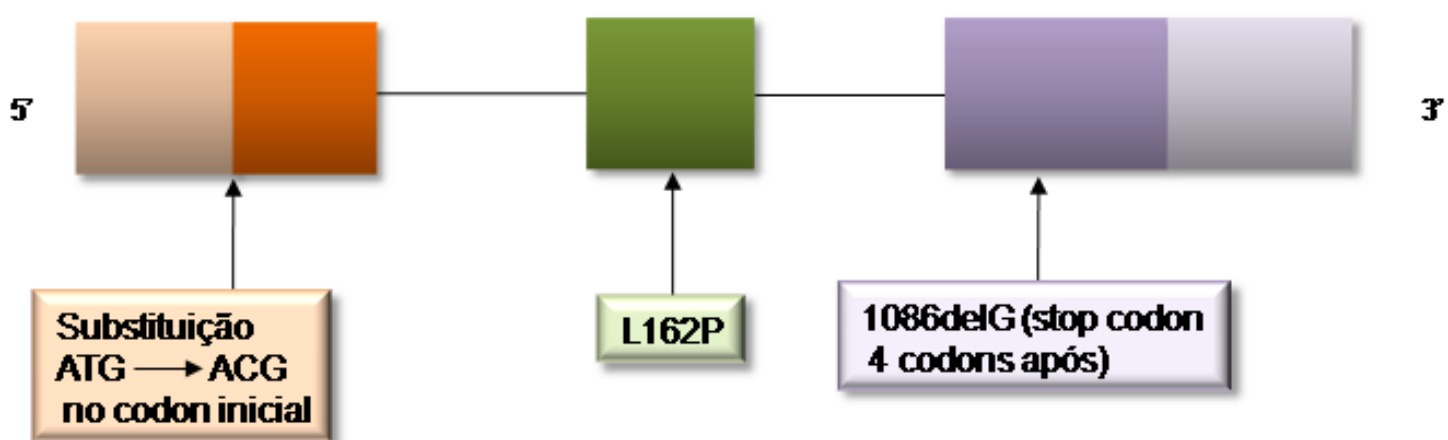

Figura 4. Gene $D H H$, seus 3 exons e as mutações encontradas. Em rosa, mutação encontrada no paciente com DG parcial $46, X Y$ com neuropatia; em amarelo e verde, mutações encontradas nos pacientes com DG completa 46, XY sem neuropatia.

Outros genes também fazem parte da cascata de desenvolvimento testicular, e há uma grande interação dos fatores de transcrição envolvidos nesta via. O gene $D A X-1$, o gene MAMDL1 e os genes autossômicos ( $L H X 9$, SOX9, DMTR1, GATA4, FOG2, WNT4 e FGF9, dentre outros) são também importantes no processo da determinação e da diferenciação testicular ${ }^{48,49}$.

\subsection{Genes e organogênese ovariana}

Ao contrário do desenvolvimento testicular, os mecanismos genéticos envolvidos no desenvolvimento ovariano precoce ainda são em sua maioria desconhecidos. 
O Dax-1 foi originalmente considerado o candidato para a determinação gonadal devido a sua localização no cromossomo $\times{ }^{50}$. No entanto, estudos com camundongos knockout indicaram que o Dax-1 não é necessário para o desenvolvimento ovariano, ao contrário, é importante para o desenvolvimento testicular. Mutações que anulam o Dax-1 têm pouco efeito sobre os ovários, mas causam disgenesia testicular importante ${ }^{51}$. Poucos genes exibem um padrão de especificidade ovariana, e nenhum ainda foi indicado como responsável pela formação inicial dos ovários ${ }^{52}$.

A hipótese do gene " $Z$ " tem sido proposta para explicar o caso onde indivíduos XX desenvolvem testículos na ausência do Sry. Este gene " $Z$ " seria normalmente expresso na gônada $X X$ para reprimir a via testicular $\mathrm{e}$ desenvolver a ovariana, enquanto que na gônada $X Y$ o gene " $Z$ " seria suprimido pelo Sry, resultando no surgimento da via testicular. Nos casos de reversão sexual feminina para masculina, esse gene " $Z$ " seria inativado ou mutado na gônada XX e então o testículo se desenvolveria, apesar da ausência do Sry ${ }^{39}$.

Corroborando com essa hipótese, foi identificado em cabras a chamada "polled/intersex syndrome" (PIS). Dois genes (Pisrti e Foxl2) foram ligados a PIS e o Foxl2 parece ser um candidato a gene "Z", em cabras $^{53}$. Em humanos, o FOXL2 (Forkhead Transcription Factor FOXL2) está ligado a BPES (síndrome da blefarofimose-ptose-epicanto-inverso), que em alguns casos está associada à falência ovariana prematura ${ }^{54}$. No entanto, ao contrário da síndrome das cabras, não há relato de reversão 
sexual em pacientes XX com BPES. Também em camundongos, mutações que anulam o Foxl2 não interferem na formação inicial dos ovários ${ }^{55}$, indicando que em humanos e camundongos, o Foxl2 parece não ser o provável gene "Z".

Embora o fator determinante ovariano e o gene " $Z$ " não tenham sido identificados, nenhuma das duas hipóteses pode ser descartada. Um caminho mais complexo poderia englobar estas duas hipóteses ${ }^{56}$.

\subsubsection{As células germinativas femininas}

O desenvolvimento sexual dimórfico das gônadas cria dois ambientes somáticos distintos que mantêm a maturação dos gametas femininos e masculinos. A mais importante diferença entre a organização testicular e a ovariana é o envolvimento das células germinativas. O desenvolvimento testicular progride normalmente na ausência de células germinativas ${ }^{57}$. No entanto, quando as células germinativas estão ausentes da gônada $X X$, os folículos ovarianos, que são as unidades funcionais do ovário, nunca se

formam ${ }^{58}$. Além disso, se as células germinativas se perdem após a formação dos folículos, estes rapidamente se degeneram ${ }^{59}$. As células germinativas parecem ter um papel regulador essencial na organização e manutenção da estrutura ovariana.

Uma vez que as células germinativas entram em meiose, elas estão fadadas a se desenvolverem em oócitos. Próximo ao nascimento, os oócitos individualmente se tornam envolvidos por uma camada de células 
escamosas da granulosa para formar os folículos primordiais. Um fator de transcrição oócito específico "basic helix-loop-helix", Figla (fator da linhagem germinativa a), que é codificado pelo gene FIG alpha, é essencial para o recrutamento das células da granulosa para que se forme o folículo primordial. Na ausência dele os folículos primordiais nunca se formam e uma depleção maciça de oócitos ocorre após o nascimento ${ }^{33}$.

Células somáticas nas gônadas XX (não nas XY) expressam Wnt4 e Folistatina no momento da determinação sexual ${ }^{60,}{ }^{61}$. Foi visto posteriormente que o Wnt4 é um regulador anterior à Folistatina (na cascata), que induz a expressão da mesma ${ }^{62}$. Defeitos semelhantes surgem em ovários sem Folistatina e sem Wnt4, indicando que eles fazem parte da mesma cascata sinalizadora.

A perda do Wnt4 ou da Folistatina causa dois defeitos nos ovários: a) o aparecimento de um vaso celômico (específico do testículo) na superfície dos ovários dos camundongos ${ }^{62,63}$ (um precoce marcador morfológico do desenvolvimento testicular e normalmente ausente no ovário); e b) ausência de células germinativas, que sofrem apoptose maciça ${ }^{60,62}$.

Outros genes parecem estar envolvidos no desenvolvimento ovariano, observados em pacientes portadores de distúrbios do desenvolvimento dessa gônada e mutações identificadas nos mesmos. Exemplos disso são mutações encontradas em pacientes $46, \mathrm{XX}$ com falência ovariana prematura nos genes dos receptores de LH e FSH ${ }^{64-67}$. 


\subsubsection{Gene FOXL2}

Enquanto o Figla ativa o programa de foliculogênese nos oócitos, outro fator de transcrição, o Foxl2, torna-se ativo nas células somáticas, especialmente nas células pré-granulosas. Embora o Foxl2 não pareça ser essencial para a formação inicial do ovário, como já dito anteriormente, ele é essencial para a diferenciação apropriada das células da granulosa durante a foliculogênese.

Mutações com ausência de atividade do Foxl2 em camundongos lembram os casos de Síndrome de Blefarofimose-ptose-epicanto-inverso (BPES) em humanos com falência ovariana prematura ${ }^{55}$. Desenvolvimento anormal dos oócitos e perda das células esteroidogênicas no interstício também foram observados. Essa evidência genética indica que a perda do Foxl2 poderia afetar a adequada diferenciação das células da granulosa e de outros tipos celulares, resultando na perda dos folículos e conseqüentemente falência ovariana prematura.

Em 2001, Crisponi e colaboradores ${ }^{68}$ clonaram o gene FOXL2 a partir de estudos em humanos com a BPES. Este gene, que codifica um fator de transcrição de 376 aminoácidos com um domínio winged helix/forkhead (Figura 5), localiza-se no cromossomo 3q23 e possui apenas um exon de 2736 pares de base, sendo os 237 primeiros pares e os 1368 últimos pares de base regiões não codificadoras. 
MMASYPEPEDAAGALLAPETGRTVKEPEGPPPSPGKGGGGGGGTAPEKPDPAQKPPYSYVALIAMAI RESAEKRLTLSGIYQYIIAKFPFYEKNKKGWQNSIRHNLSLNECFIKVPREGGGERKGNYWTLDPACED MFEKGNYRRRRRMKRPFRPPPAHFQPGKGLFGAGGAAGGCGVAGAGADGYGYLAPPKYLQSGFLN NSWPLPQPPSPMPYASCQMAAAAAAAAAAAAAGPGSPGAAAVVKGLAGPAASYGPYTRVQSMALP PGVVNSYNGLGGPPAAPPPPPHPHPHPHAHHLHAAAAPPPAPPHHGAAAPPPGQLSPASPATAAPP APAPTSAPGLQFACARQPELAMMHCSYWDHDSKTGALHSRLDL

Figura 5. Seqüência de aminoácidos da proteína FOXL2. Em azul, domínio winged helix/forkhead; em verde, sequência poliA (14 alaninas); em amarelo e vermelho, mutações descritas em pacientes com falência ovariana prematura isolada (A221_A230 del e Y258N, respectivamente).

Em humanos, foram encontradas mutações no gene FOXL2 em duas pacientes (numa coorte de 70) com falência ovariana prematura isolada 54 (Figura 5). Uma delas, uma paciente eslovena, apresentava amenorréia primária com desenvolvimento normal de caracteres sexuais secundários ${ }^{69}$. Aos 17 anos procurou auxilio médico por apresentar amenorréia, quando foi feito o diagnóstico de falência ovariana e iniciada terapia de reposição hormonal. Aos 22 anos, ela se casou e parou o tratamento por vontade própria. Surpreendentemente, após 16 meses, ela ficou grávida sem tratamento algum. Seis meses após o parto, ela apresentou sangramento vaginal espontâneo, mas tornou-se amenorréica novamente logo em seguida. Em seguimento, ela demonstrou desejo de engravidar novamente, e apenas com acompanhamento clínico, realizando ultrassonografia pélvica a cada 2-4 semanas, foi detectado um folículo em desenvolvimento, e novamente ela engravidou, e concebeu outra criança a termo e saudável.

Em 2002 e 2004, novos estudos em pacientes com falência ovariana prematura não detectaram nenhuma mutação no gene FOXL2 em 70 e 120 mulheres, respectivamente, sugerindo que esse gene não deva ser uma 
causa importante do distúrbio ${ }^{70,71}$. Apesar disso, acreditamos ser importante avaliarmos esse gene em uma casuística brasileira, já que não há relato de estudo em nossa população, e haja vista o desfecho do caso ocorrido com a paciente eslovena. Pacientes com falência ovariana prematura freqüentemente buscam soluções para seu problema de fertilidade; mulheres afetadas poderiam, então, fazer escolhas, e eventualmente a informação do defeito genético poderia ter impacto em relação à fertilidade dessas mulheres ${ }^{69}$. 
2 Objetivos 
1- Analisar os aspectos clínicos, laboratoriais e anatomopatológicos dos pacientes portadores de distúrbios do desenvolvimento gonadal que acompanham o ambulatório de Endocrinologia do Desenvolvimento do Hospital das Clínicas de São Paulo.

2- Pesquisar mutações nos genes CBX2 e TCF21 em pacientes portadores de distúrbios da determinação gonadal 46,XX e 46,XY.

3- Pesquisar a presença de mutações no gene $D H H$ em pacientes portadores de distúrbios da determinação gonadal 46,XY.

4- Pesquisar a presença de mutações no gene FOXL2 em pacientes portadores de distúrbios da determinação gonadal 46,XX. 
3 Metodologia 


\subsection{Considerações éticas}

Este estudo foi conduzido de acordo com princípios éticos, seguindo as orientações contidas na declaração de Helsinki. O consentimento por escrito foi obtido de todos os pacientes, pais ou tutores antes que os procedimentos de pesquisas fossem iniciados. O protocolo de estudo foi submetido ao Comitê de Ética em pesquisa do Hospital das Clínicas da FMUSP (CAPPesq) e aprovado.

\subsection{Casuística}

\subsubsection{Critérios para classificação dos pacientes}

Esse trabalho baseou-se na nova nomenclatura discutida na Conferência Internacional sobre o Consenso em Intersexo realizado em 2006 (Anexo A). Os pacientes denominados portadores de Distúrbios do Desenvolvimento Gonadal (DDG) 46, XY foram subclassificados em: disgenesia gonadal completa e disgenesia gonadal parcial. O diagnóstico de disgenesia gonadal 46,XY forma completa e parcial foi baseado na classificação de Mendonça et al, 2005 ${ }^{72}$. Decidimos classificar como 
disgenesia gonadal parcial os pacientes com síndrome de regressão testicular embrionária, já que ela foi definida por Marcantonio S.M. et al em $1994^{14}$ como parte do espectro clínico de disgenesia gonadal 46,XY, e como disgenesia gonadal completa $46, \mathrm{XY}$ os pacientes com agenesia gonadal, por apresentarem grande sobreposição de apresentação clínica e também parecerem ser um espectro do mesmo distúrbio. Sendo assim, os pacientes com diferenciação sexual anormal, com grau variável de masculinização da genitália externa e interna, dependente do tempo de atividade da gônada antes de sua regressão, e na ausência de tecido gonadal ao nascimento unilateral ou bilateral foram definidos como portadores de disgenesia gonadal.

Para classificar as pacientes com DDG 46, XX nós utilizamos a definição de falência ovariana prematura, e decidimos subclassificar em disgenesia gonadal apenas as pacientes com amenorréia primária, de acordo com a definição clássica de DG pura ${ }^{73}$. As pacientes sindrômicas foram classificadas de acordo com suas síndromes.

\subsubsection{Pacientes}

Foram estudados 60 pacientes portadores de DDG, distribuídos em dois grupos de acordo com o sexo cromossômico, descritos abaixo. Os dados clínicos, laboratoriais e anatomopatológicos estão resumidos nas Tabelas 17 a 22 (Anexo C), 


\section{Grupo I - Pacientes DDG 46,XY}

Foram estudados 41 pacientes com quadro clínico, laboratorial, radiológico e citogenético compatíveis com o diagnóstico de DDG 46,XY. Este diagnóstico foi confirmado pelo estudo anatomopatológico dos tecidos gonadais da maioria dos pacientes, que foram obtidos durante o tratamento cirúrgico dos mesmos.

Os genes SRY, SF-1 e DAX-1 haviam sido previamente analisados e a presença de mutações foi descartada. ${ }^{74}$

Esse grupo foi dividido em 2 subgrupos :

$\checkmark \quad$ Disgenesia Gonadal Completa (DGC) - 13 pacientes

$\checkmark \quad$ Disgenesia Gonadal Parcial (DGP) - 28 pacientes

Dos 41 pacientes selecionados, 09 constituíam casos familiais e 32 casos esporádicos da doença.

\section{Casos familiais}

$\checkmark \quad$ Família 1-estudadas 2 irmãs portadoras de DGC

$\checkmark \quad$ Família 2-estudadas 2 irmãs portadoras de DGP

$\checkmark \quad$ Família 3- estudados 2 pacientes portadores de DGP (tio e sobrinho)

$\checkmark \quad$ Família 4- estudados 2 pacientes portadores de DGP (tia e sobrinho)

$\checkmark \quad$ Família 5- Estudamos em especial uma família constituída por duas irmãs, filhas de pais primos de $1^{0}$ grau, ambas portadoras de disgenesia gonadal, porém uma apresentava o cariótipo 46,XX e outra apresentava o cariótipo 46,XY. Nessas duas pacientes, o gene LHX9 foi previamente estudado, e não foi encontrada nenhuma alteração ${ }^{21}$. 


\section{Grupo II - Pacientes DDG 46,XX.}

Foram estudadas 19 pacientes com quadro clínico, laboratorial, radiológico e citogenético compatíveis com o diagnóstico de DDG 46,XX.

Das 19 pacientes selecionadas, 11 constituíam casos familiais e 08 casos esporádicos da doença.

\section{Casos familiais}

$\checkmark \quad$ Família 6-estudadas 2 irmãs gêmeas portadoras de DG 46,XX

$\checkmark \quad$ Família 7-estudadas 2 irmãs portadoras de DG 46,XX

$\checkmark \quad$ Família 8- estudadas 2 irmãs portadoras de DG 46,XX

$\checkmark \quad$ Família 9- estudadas 2 irmãs portadoras de DG 46,XX

$\checkmark \quad$ Família 10- estudadas 2 irmãs portadoras de DG 46,XX

$\checkmark \quad$ O $11^{\circ}$ caso familial faz parte da Família 5 , que é a paciente com disgenesia gonadal 46, XX irmã do paciente do DGC 46, XY

\subsubsection{Grupo Controle}

Os indivíduos do Grupo Controle foram obtidos a partir de um banco constituído pelo DNA de funcionários do Laboratório de Hormônios do LIM42 da Faculdade de Medicina da USP, professores, alunos e ex-alunos da residência de Endocrinologia do Hospital das Clínicas da USP. Todos 
doaram seu DNA voluntariamente e autorizaram o uso do mesmo para estudo de controles normais. Clinicamente, todos são adultos, apresentaram puberdade espontânea e no tempo normal. Nenhum indivíduo foi submetido a cirurgia corretora de genitália. Todas as mulheres apresentaram menarca no tempo normal.

\subsection{Avaliação clínica}

Os pacientes foram acompanhados na Unidade de Endocrinologia do Desenvolvimento, Disciplina de Endocrinologia do Hospital das Clínicas da FMUSP, no período de 1975 a 2008. Todos os pacientes foram submetidos a exame clínico geral, sendo detalhada a avaliação da genitália externa. Foram investigados os antecedentes familiares em busca de relatos de consangüinidade, assim como de outros indivíduos afetados na família.

\subsection{Avaliação por imagem}

Os pacientes foram submetidos à ultrassonografia pélvica e urogenitografia com o objetivo de caracterizar a presença de seio urogenital e de derivados müllerianos. 


\subsection{Avaliação hormonal}

Essa avaliação constituiu-se de dosagens basais de hormônio luteinizante (LH), hormônio folículo estimulante (FSH), testosterona (T) e estradiol $\left(E_{2}\right)$, além de teste de estímulo com gonadotrofina coriônica humana (hCG) na maioria dos pacientes. Utilizamos 50 a $100 \mathrm{UI} / \mathrm{Kg}$ de peso em 4 doses e as dosagens hormonais foram realizadas pré e 72 horas após a última injeção intramuscular de hCG conforme teste padronizado no nosso serviço ${ }^{75}$. No período de estudo foram utilizados dois métodos de dosagem para as gonadotrofinas séricas, estradiol e testosterona, a saber, radioimunoensaio com duplo anticorpo (Wallac, Turku, Finlândia) para LH, $\mathrm{FSH}, \mathrm{E}_{2}$ e ensaio imunofluorométrico em "kits" AutoDelfia (Delfia, Wallac, Turku, Finland) para LH, FSH, $\mathrm{E}_{2}$ e T.

Outros exames hormonais foram realizados nos pacientes a fim de se excluírem outros possíveis distúrbios causadores dos fenótipos encontrados; dentre eles, destacamos o cortisol, androstenediona, dehidroepiandrosterona, dehidroepiandrosterona-sulfato, aldosterona, composto S e ACTH. O resultado de todos esses exames foi normal.

Os resultados dos pacientes foram comparados aos valores de indivíduos normais estudados no mesmo Laboratório de Hormônios e Genética Molecular LIM/42. 


\subsection{Avaliação psicológica}

Os pacientes e familiares foram avaliados pelas psicólogas Marlene Inácio e Elisa Verduguez através de entrevistas, aplicação de testes projetivos como o HTP - house, tree, person test, o desenho livre da família e o teste de Szondi, teste de inteligência não verbal de Form C Pierre, Weil e Eva Nick, e questionários para investigação da identidade sexual; os pacientes tiveram a definição de sua identidade sexual antes do tratamento cirúrgico e posteriormente seguimento da adequação do sexo social.

\subsection{Tratamento cirúrgico}

Os pacientes submeteram-se a tratamento cirúrgico para correção da genitália externa e interna, com adequação ao sexo social. As cirurgias foram realizadas pelas equipes do Dr. Frederico A. Q. Silva e Dr. Francisco Tibor Denes, da Disciplina de Urologia, do Hospital das Clínicas da FMUSP.

\subsection{Avaliação anatomopatológica}

As estruturas retiradas durante o procedimento cirúrgico terapêutico foram submetidas a estudo anatomopatológico. Este material foi fixado em parafina e corado por hematoxilina-eosina. Cortes representando todo o 
material da maioria dos pacientes foram revistos por microscopia óptica pela mesma patologista, Dra. Filomena Marino Carvalho, médica assistente da Disciplina de Anatomia Patológica do HC da FMUSP. Na revisão deste material atenção especial foi dedicada à caracterização e classificação do tecido gonadal e derivados müllerianos e wolffianos.

\subsection{Avaliação citogenética}

O estudo citogenético consistiu na realização do cariótipo a partir de cultura de linfócitos de sangue periférico e análise de 50 células através de técnica de coloração convencional e bandamento $\mathrm{G}^{76}$, realizado no Laboratório de Hormônio e Genética Molecular, LIM/42 da Disciplina de Endocrinologia pelas biólogas Maria Aparecida Medeiros e Mirian Yumie Nishi.

\subsection{Avaliação imunológica}

As pacientes com DDG 46, XX foram avaliadas quanto à possibilidade de apresentarem doenças auto-imunes a partir da história pessoal e familiar, quadro clínico sugestivo e pela presença ou não de alguns auto-anticorpos. Os auto-anticorpos dosados foram anticorpos antitireoglobulina, anti-tireoperoxidase (TPO), fatores nucleares, anti-músculo 
liso, anti-célula parietal, anti-mitocondrial, anti-citosol hepático, fator reumatóide e anti-célula esteroidal (StCA). Este último, também denominado anticorpo anti-ovário (e/ou anti-testículo), é detectado por imunofluorescência indireta, a partir de testículos e ovários de primatas, e recentes trabalhos identificaram as enzimas P450scc (P450 side chain cleavage) e a 17 alfa-hidroxilase como principais auto-antígenos alvos desse anticorpo ${ }^{77}$. Os outros anticorpos foram realizados a partir dos métodos de fluoroimunoensaio (Wallac Auto DELFIA - anti tireoperoxidase e antitireoglobulina) e imunofluorescência indireta (anti-célula parietal, anti músculo liso, anti-mitocondrial, fatores nucleares). O StCA está presente em 60-87\% de mulheres com amenorréia secundária e auto-imunidade adrenal e/ou doença de Addison, em 100\% de mulheres com amenorréia primária e doença de Addison $^{12}$, mas apenas em $3 \%$ de mulheres com falência ovariana prematura idiopática não associada a doença auto-imune (adrenal ou outro órgão) ${ }^{78}$.

Até o momento nenhum auto-anticorpo foi validado como sendo critério diagnóstico de ooforite auto-imune ${ }^{79}$. Sendo assim, selecionamos as pacientes que não apresentavam provável distúrbio ovariano auto-imune a partir da história pessoal de presença (ou não) de outras doenças autoimunes e/ou a presença (ou não) de auto-anticorpos. 


\subsection{Estudo Molecular}

\subsubsection{Preparação das amostras}

\section{Extração do DNA genômico de leucócitos periféricos}

As amostras de DNA genômico foram obtidas a partir de leucócitos de sangue periférico dos pacientes, de seus familiares quando disponíveis e de controles normais, masculinos e femininos, utilizando-se protocolos padronizados.

\section{Protocolo para extração de DNA}

Para extração do DNA genômico, foi utilizado o protocolo de Miller e colaboradores $^{80}$, descrito a seguir.

O DNA genômico foi extraído a partir de leucócitos periféricos: $10 \mathrm{~mL}$ de sangue venoso em ácido etileno diaminotetracético (EDTA pH 8) foram colhidos. Um botão leucocitário foi obtido a partir da lise dos glóbulos vermelhos utilizando-se a solução de lise (114 mM de $\mathrm{NH}_{4} \mathrm{Cl}, 1 \mathrm{mM}$ de $\mathrm{NH}_{4} \mathrm{HCO}_{3}$ ) com incubação a $4^{\circ} \mathrm{C}$ por 30 minutos. Centrifugou-se o material a $4^{\circ} \mathrm{C}$ por 15 minutos a $3000 \mathrm{rpm}$ desprezando-se o sobrenadante - estes procedimentos foram repetidos por 2 vezes. O botão de células foi então suspenso em solução tampão PK (100 mM de NaCl, 10 mM de Tris- $\mathrm{HCl}$ pH 8, $1 \mathrm{mM}$ de EDTA pH 8) com 1/10 do volume de dodecilsulfato de sódio a 
$10 \%$ (SDS) e $100 \mu \mathrm{g} / \mathrm{mL}$ de sangue de proteinase $\mathrm{K}$ e mantido a $37^{\circ} \mathrm{C}$ por uma noite. No dia seguinte o material foi submetido à extração com fenol saturado ( $\mathrm{pH} 7,8)$ : clorofórmio:álcool isoamílico (25:24:1) duas vezes e uma vez com clorofórmio:álcool isoamílico (24:1). No processo de extração, após centrifugação a $4^{\circ} \mathrm{C}$ por 5 minutos a $2500 \mathrm{rpm}$, o sobrenadante foi utilizado na fase seguinte. O DNA foi então precipitado com 1/10 de volume de acetato de sódio (3M pH 7) e 2 volumes de etanol absoluto gelado. O DNA obtido foi lavado 2 vezes com etanol $70 \%$ gelado e uma vez com etanol absoluto gelado e posteriormente desidratado em "Speed Vac" (Integrated Speed Vac System/Savant, ISS 100) e ressuspenso em 500 a $1000 \mu \mathrm{L}$ de solução de TE 10:0,1 (10 mM de Tris- $\mathrm{HCl}$ pH 8, 0,1 mM de EDTA pH 8) ${ }^{80}$. A concentração do DNA foi medida em espectrofotômetro (Ultrospec III Pharmacia Biotech) nos comprimentos de onda de 260 e 280 nm. A relação $260 / 280$ igual a 1,8 foi utilizada para caracterizar a pureza do material. As amostras foram armazenadas a $4^{\circ} \mathrm{C}$ até sua utilização.

\subsubsection{Reação de Polimerização em Cadeia (PCR)}

O DNA genômico foi amplificado através da reação de polimerização em cadeia (PCR) utilizando-se oligonucleotídeos (primers) específicos para os genes CBX2, TCF21, DHH e FOXL2.

Foram utilizadas na PCR: 100 ng de DNA genômico, $200 \mu \mathrm{M}$ de cada desoxinucleotídio (dNTP), 0,5 mM(20 pmol) de cada "primer", além do tampão e 2,5 UI de enzima Taq polimerase em um volume final de $25 \mu \mathrm{L}$. 


\subsubsection{Protocolo de amplificação}

As amostras de DNA foram submetidas aos protocolos de amplificação específicos para cada gene e par de oligonucleotídeos. Utilizamos um termociclador automático (Perkin Elmer 9700). Todas as amplificações foram acompanhadas de um controle negativo (todos os reagentes exceto o DNA) para descartar contaminação da reação. As amostras amplificadas foram verificadas em gel de agarose a $1 \%$ preparado com TAE 1X e corado com brometo de etídio $(0,5 \mu \mathrm{g} / \mathrm{mL}$ de gel); observadas em transiluminador ultravioleta e fotografadas com filme Polaroid (667-3 1/4 X 4 1⁄4) e/ou máquina digital.

\section{Gene CBX2}

Os oligonucleotídeos iniciadores utilizados foram desenhados através do programa Primer3 pick primers from a DNA sequence ${ }^{81}$. O protocolo de amplificação foi desenvolvido durante o estudo (Tabela 11, Anexo B).

\section{Gene TCF21}

Os oligonucleotídeos iniciadores utilizados do $1^{0}$ exon foram desenhados no programa Primer $3^{81}$, e os do exon dois foram compilados do estudo de Schonberger, et al ${ }^{82}$. O protocolo de amplificação foi desenvolvido durante o estudo (Tabela 12, Anexo B). 


\section{Gene DHH}

Os oligonucleotídeos iniciadores utilizados foram desenhados no programa Primer3 ${ }^{81}$, exceto o primeiro par de oligonucleotídeos do $3^{\circ}$ exon, já previamente desenhado pelos autores Umehara et al ${ }^{46}$. O protocolo de amplificação foi desenvolvido durante o estudo (Tabela 13, Anexo B).

\section{Gene FOXL2}

Os oligonucleotídeos iniciadores utilizados foram desenhados no programa Primer $3^{81}$, e foram feitos dois pares de primers para amplificação do exon único, por ser muito extenso. O protocolo de amplificação foi desenvolvido durante o estudo (Tabela 14, Anexo B).

\subsubsection{Seqüenciamento direto}

As amostras de DNA foram amplificadas utilizando-se os oligonucleotídeos específicos. Os produtos de PCR de fita dupla foram purificados com a enzima ExoSAP-IT ${ }^{\circledR}(2 \mu \mathrm{L}$ para $5 \mu \mathrm{L}$ de produto de PCR) a $37^{\circ} \mathrm{C}$ durante 15 minutos. Ambas as enzimas são inativadas a $80{ }^{\circ} \mathrm{C}$ por 15 minutos. Foram utilizados os mesmos oligonucleotídeos descritos para as PCRs, com o acréscimo de um oligonucleotídeo para o seqüenciamento do gene FOXL2, desenhado com o programa Primer 3 (Tabela 4, Anexo 2). Todos os produtos de PCR foram seqüenciados usando o kit $A B I$ Prism $^{T M}$ 
BigDye Terminator (Perkin Elmer) seguido por purificação em colunas Centri-Sep (Princenton Separations, Adelphia, NJ, USA). Utilizamos o seqüenciador automático ABI-Prism Genetic Analyser 3100 (Perkin Elmer Cetus) para análise das amostras. Os procedimentos que apresentaram alteração foram repetidos em duplicata para confirmação dos resultados.

\subsubsection{Extração de RNA}

Para o estudo da alteração intrônica encontrada no gene $D H H$ foi necessário estudar o RNA do testículo do paciente portador da variante. Esse testículo, retirado no momento da gonadectomia e genitoplastia do paciente, foi armazenado em nitrogênio líquido para que mantivesse a integridade de seu RNA e suas proteínas. A extração do RNA do tecido estudado foi realizada utilizando o método do tiocianato de guanidina-fenolclorofórmio $\left(\right.$ Trizol $^{\circledR}$ ), descrito a seguir:

Retirado o tecido testicular do nitrogênio líquido, mergulhado o mesmo em $3 \mathrm{~mL}$ de Trizol $^{\circledR}$. Quando o tecido foi descongelado, o mesmo foi triturado, e em seguida homogeneizado à solução de Trizol ${ }^{\circledR}$ e centrifugado a $1200 \mathrm{~g}$ por $10 \mathrm{~min}$ a $4^{\circ} \mathrm{C}$; em seguida, transferido o sobrenadante, e deixado secar por 5 min em temperatura ambiente.

Separação de fases: adicionado $200 \mu \mathrm{L}$ de clorofórmio para cada $\mathrm{mL}$

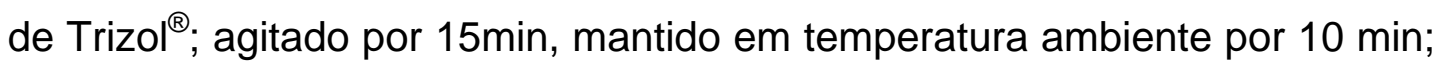
em seguida, foi centrifugado a $12000 \mathrm{~g}$ por $15 \mathrm{~min}$ a $4^{\circ} \mathrm{C}$. Após esta centrifugação observou-se a formação de 3 fases da solução: um 
sobrenadante translúcido contendo o RNA total, uma fase intermediária leitosa (DNA) e uma fase inferior rosada (proteínas).

O sobrenadante foi transferido para novos tubos e foram acrescentados $500 \mu \mathrm{L}$ de isopropanolol para precipitação do RNA total. As amostras foram deixadas 10 minutos em temperatura ambiente e depois centrifugadas a $12.000 \mathrm{~g}$ por 10 minutos a $4^{\circ} \mathrm{C}$. Após esta centrifugação, o sobrenadante foi desprezado e o "pellet" de RNA foi lavado uma vez com etanol 75\% a -20 ${ }^{\circ} \mathrm{C}$, seguido por centrifugação a $1200 \mathrm{~g}$ por 5 minutos a $4^{\circ} \mathrm{C}$.

Após remoção do etanol por inversão, deixamos o tubo contendo o "pellet" de RNA invertido em temperatura ambiente por 30 minutos para secar. Após este período, o "pellet" de RNA foi suspenso novamente em 50 $\mu \mathrm{L}$ de água livre de RNAse e incubamos a $65^{\circ}$ por 20 minutos. Duas alíquotas de $5 \mu \mathrm{L}$ foram obtidas, sendo que uma foi utilizada para quantificação e avaliação da concentração do RNA total extraído em espectrofotômetro, e a outra foi submetida a eletroforese em gel de agarose a $1 \%$ com posterior visualização em transiluminador ultravioleta e fotografadas com sistema digital de captura de imagem para avaliação da integridade do RNA extraído (transportador).

O RNA extraído foi então submetido à transcrição reversa (RT "reverse transcription step") no qual o DNA complementar (cDNA) é produzido através do uso de "primers" randômicos provenientes do "kit" High Capacity cDNA Archive Kit ${ }^{\circledR}$ (Applied Biosystems). Uma quantidade semelhante de RNA $(16 \mu \mathrm{g})$ foi utilizada para RT de todas as amostras. 
Realizada a PCR do cDNA do testículo utilizando-se primers exônicos englobando os exons 2 e 3 , desenhados no Primer $3^{81}$. O protocolo de amplificação foi desenvolvido durante o estudo (Tabela 15, Anexo B). Também foram realizadas PCRs de outros genes sabidamente expressos em testículos: $A M H$ (hormônio anti-mulleriano) e $R A$ (receptor de andrógenos) para se avaliar a presença ou não de células de Sertoli íntegras nesse testículo, visto que se trata de um testículo disgenético. Os primers foram desenhados no Primer $3^{81}$. Os protocolos de amplificação foram realizados previamente por outro estudo no próprio laboratório (Tabela 16, Anexo B).

\subsubsection{Detecção de variantes alélicas por digestão enzimática}

Para a análise da variante no gene $C B X 2$ ainda não descrita na literatura (p.C132R / g.394 T>C) foi realizado o estudo da frequência dessa variante em controles normais (indivíduos adultos sem alteração do desenvolvimento sexual $-\mathrm{n}=103$ ). Como a enzima Ecil (BioLabs, New England) cria um sítio de clivagem na presença da variante encontrada, foi utilizada a técnica de digestão enzimática. Para cada reação, foram utilizados $25 \mu \mathrm{L}$ de PCR, 0,4 UI da enzima Ecil $(0,2 \mu \mathrm{L}), 5 \mu \mathrm{L}$ do tampão específico NeBuffer 2 (BioLabs, New England) e 24,8 $\mu \mathrm{L}$ de H2O para se obter um volume final de $50 \mu \mathrm{L}$. As amostras foram incubadas por 3 horas a $37^{\circ} \mathrm{C}$. Um controle de reação, sabidamente sem a variante, foi incluído no experimento. Um segundo controle mutante para a variante alélica descrita 
também foi utilizado (em heterozigose, que é a PCR do paciente em estudo). Os produtos da digestão foram submetidos a uma eletroforese em gel de agarose a 1,0\% em tampão TAE e os fragmentos de DNA foram visualizados em luz ultravioleta após coloração com brometo de etídio. A seqüência mutada apresentava fragmentos de 411 e 437 pb enquanto que a seqüência normal apresentava um fragmento de 848 pb.

\subsubsection{Detecção de variantes alélicas por PCR e seqüenciamento}

As outras variantes alélicas encontradas nos genes CBX2, TCF21, DHH e FOXL2 foram analisadas por seqüenciamento de 60 a 180 controles com desenvolvimento sexual normal, utilizando a mesma metodologia anteriormente descrita. Para essas variantes alélicas o estudo a partir de enzimas de restrição não foi possível, de forma que foram realizados PCR e seqüenciamento dos controles, variando o número de controles de acordo com a frequência em que a variante estudada ia sendo encontrada nos indivíduos. 
4 Resultados 


\subsection{Grupo I - Pacientes com DDG 46,XY}

\subsubsection{Aspectos clínicos}

Disgenesia gonadal completa (DGC) (Tabela 17, Anexo C)

As pacientes portadoras de disgenesia gonadal forma completa (DGC), por apresentarem genitália feminina normal, somente procuraram a avaliação médica mais tardiamente por volta da $2^{\mathrm{a}}$ e $3^{\mathrm{a}}$ décadas, em média aos 21,6 anos de idade, exceto a paciente 11 , que foi avaliada pela primeira vez somente aos 45 anos. O sintoma mais prevalente encontrado foi amenorréia primária, presente em todas as pacientes. A ausência de desenvolvimento dos caracteres sexuais secundários esteve presente em 11 das 13 pacientes. As duas pacientes restantes (casos 3 e 8) apresentaram

mamas desenvolvidas ao primeiro exame físico. A Tabela 1 resume os aspectos clínicos das pacientes com DGC. 
Tabela 1- Dados clínicos dos pacientes com DDG 46,XY com disgenesia gonadal completa

\begin{tabular}{|c|c|}
\hline Dados clínicos & Resultados I número de pacientes \\
\hline \multirow[t]{2}{*}{ Sexo social e genitália externa } & Feminino: todos (13) \\
\hline & Ausência de telarca e menarca: 11 \\
\hline \multirow[t]{2}{*}{ Quadro clínico inicial } & Presença de mamas e ausência de \\
\hline & menarca: 2 \\
\hline \multirow{2}{*}{ Idade da $1^{a}$ avaliação } & $1^{\mathrm{a}}$ e $2^{\mathrm{a}}$ década: 6 \\
\hline & $3^{\mathrm{a}}$ década: 7 \\
\hline Pais consanguíneos & Sim 4: Não: 8 \\
\hline Casos familiais & 3 (2 famílias) \\
\hline
\end{tabular}

Dos 13 casos avaliados, três eram familiares. Duas irmãs (casos 8 e 9) pertenciam à família 1 cujos pais não eram consanguíneos. A outra paciente (caso 13) pertencia à família 5, era irmã do caso 60 portadora de DG 46,XX e seus pais eram consangüíneos. Três casos esporádicos de DGC apresentavam consangüinidade entre os pais (casos 3, 7 e 11) O sexo social feminino foi atribuído a todas as pacientes.

\section{Disgenesia gonadal parcial (DGP) (Tabela 19 Anexo C)}

Os casos de disgenesia gonadal parcial (DGP) foram diagnosticados entre a $1^{\mathrm{a}}$ e $2^{\mathrm{a}}$ décadas, com média de idade cronológica de 13,6 anos, sendo que quatro pacientes somente foram diagnosticados na $3^{\mathrm{a}}$ e $4^{\mathrm{a}}$ décadas de vida, apesar do grau de ambigüidade da genitália externa (pacientes 20, 27, 31 e 32). (Tabela 2). Os pacientes 21, 35 e 36, apesar da primeira avaliação em nosso serviço ter sido na $3^{a}$ e $4^{a}$ décadas de vida, já haviam sido avaliados previamente em outra unidade médica. 
Tabela 2 - Dados clínicos dos pacientes com DDG 46,XY com disgenesia gonadal parcial

\begin{tabular}{|c|c|}
\hline Dados clínicos & Resultados / número de pacientes \\
\hline Sexo social & $\begin{array}{l}\text { Feminino: } 09 \text { / Masculino: } 16 \text { / M } \rightarrow \mathrm{F}: 3 \\
\text { total:28) }\end{array}$ \\
\hline Genitália externa & Ambígua: 25 / Micropênis: 3 \\
\hline Quadro clínico inicial (queixa inicial) & $\begin{array}{l}\text { Genitália ambígua ao nascimento: } 21 \\
\text { Amenorréia primária: } 2 \text { (1 com virilização) } \\
\text { Micropênis: } 5 \text { ( } 2 \text { com criptorquidia) }\end{array}$ \\
\hline Idade da $1^{a}$ avaliação em nosso serviço & $\begin{array}{l}1^{\mathrm{a}} \text { e } 2^{\mathrm{a}} \text { década: } 21 \\
3^{\mathrm{a}} \text { e } 4^{\mathrm{a}} \text { década: } 7\end{array}$ \\
\hline Pais consanguíneos & Sim 3: Não: 23 (não informado: 2) \\
\hline Casos familiais & 6 (3 famílias) \\
\hline
\end{tabular}

Dos 28 pacientes avaliados, seis eram familiares pertencentes as famílias 2 (casos 14 e 15, que eram irmãs), 3 (casos 28 e 29 que eram tio materno e sobrinho) e 4 (casos 39 e 40 que eram tio materno e sobrinho). Nenhuma dessas famílias apresentava consangüinidade. Três pacientes com DGP esporádica apresentavam pais consangüíneos (casos 21, 26 e 41).

Apenas 32,14\% apresentaram sexo social feminino. A mudança de sexo social só ocorreu nos pacientes com DGP: três pacientes trocaram o sexo social de masculino para feminino (casos 29, 32 e 41), sendo que dois destes fizeram esta troca ainda na infância e um paciente mudou de sexo social aos 30 anos (caso 32).

A presença do seio urogenital foi identificada em $39,2 \%$ dos pacientes. 


\subsubsection{Aspectos hormonais}

\section{Disgenesia gonadal completa (DGC) (Tabela 17, Anexo C)}

As dosagens de gonadotrofinas, LH e FSH, apresentaram níveis elevados com predomínio do FSH, compatíveis com o diagnóstico de hipogonadismo hipergonadotrófico em todas as pacientes com DGC, exceto em duas pacientes, sendo que uma foi avaliada no período pré-puberal (caso 09), e outra no período puberal (caso 08) (Tabela 3). Todas as pacientes que dosaram a testosterona tinham nível basal desse hormônio baixo sem qualquer resposta ao estímulo com hCG, confirmando o comprometimento gonadal severo da síntese de andrógenos pelas células de Leydig (apesar de que a maioria das pacientes não realizou o teste do hCG).

Tabela 3 - Dados hormonais dos pacientes com DDG 46,XY portadores de disgenesia gonadal completa

\begin{tabular}{ll}
\hline Dados hormonais & Resultados / número de pacientes \\
\hline LH e FSH & Pré-púbere: 2 \\
& Elevado: 11 \\
Testosterona basal & $<30 \mathrm{ng} / \mathrm{dL}: 9$ / >30 e <40: 3 / ñ realizado: 1 \\
Testosterona pós hCG & $>150 \mathrm{ng} / \mathrm{dL}: 3 /$ ñ realizado: 10 \\
\hline
\end{tabular}

Disgenesia gonadal parcial (DGP) (Tabela 19, Anexo C)

No grupo de pacientes com DGP também se evidenciaram os mesmos achados de hipogonadismo hipergonadotrófico, com elevação das 
gonadotrofinas, (exceto os pacientes 15, 17, 19, e 24 que foram avaliados em idade pré-puberal), níveis baixos de testosterona e ausência de resposta ao estímulo com hCG (Tabela 4). Cinco pacientes, no entanto, apresentaram resposta ao hCG (casos 15, 17, 19, 20 e 22), e no caso 36 a testosterona basal estava aumentada devido a uma degeneração do testículo disgenético (encontrada no exame histopatológico, sugerindo talvez uma alteração préneoplásica) e produção tardia de testosterona.

Tabela 4 - Dados hormonais dos pacientes com DDG 46,XY portadores de disgenesia gonadal parcial

\begin{tabular}{ll}
\hline Dados hormonais & Resultados I número de pacientes \\
\hline LH e FSH & Pré-púbere: 4 \\
& Elevado: 18 (não realizado: 6$)$ \\
Testosterona basal & $<30 \mathrm{ng} / \mathrm{dL}: 14$ \\
& $>30 \mathrm{ng} / \mathrm{dL}: 10$ (não realizado: 4) \\
Testosterona pós hCG & $<150 \mathrm{ng} / \mathrm{dL}: 12$ \\
& $>150 \mathrm{ng} / \mathrm{dL}: 5$ (não realizado: 11) \\
\hline
\end{tabular}

\subsubsection{Aspectos histológicos}

\section{Disgenesia gonadal completa (DGC) (Tabela 18, Anexo C)}

Os genitais internos das pacientes com DGC evidenciaram gônadas disgenéticas, em fita, em $81 \%$ dos casos estudados (os casos 8 e 9 foram gonadectomizados em outro serviço, e não tivemos acesso ao estudo 
anatomopatológico) (Tabela 5). Em todas as pacientes foi detectada a presença de útero e as trompas uterinas foram identificadas em 63,3\% das pacientes e não descritas no exame anatomopatológico em dois casos (4 e 9), sendo que no caso 8 e 9 o material não estava disponível. A presença de remanescentes de derivados wolffianos foi identificada em três pacientes (1, 7 e 11) e a presença de epidídimo em apenas um caso (3).

Tabela 5 - Anatomopatológico de pacientes com DG completa 46,XY

\begin{tabular}{ll}
\hline Anatomopatológico (AP) - DG completa 46, XY & Resultados / número de pacientes \\
\hline \multirow{2}{*}{ Gônadas } & Disgenéticas bilaterais: 9 \\
& Ausentes: 2 \\
& (Material não disponível: 2) \\
Derivados Müllerianos no AP & Presentes: 9 \\
(tuba uterina) & Ausentes: 2 \\
& (Material não disponível: 2) \\
& Presentes: 3 (remanescentes) e 1 \\
Derivados Wolffianos no AP & (epidídimo) \\
& Ausentes: 6 / não disponível: 3 \\
\hline
\end{tabular}

\section{Disgenesia gonadal parcial (DGP) (Tabela 20, Anexo C)}

Nos pacientes com DGP, a genitália interna apresentou características diversas composta por gônadas disgenéticas, testículos prépúberes normais e ausência de testículos (Tabela 6). A presença de gonadoblastoma associado à gônada disgenética foi detectado em dois pacientes (18 e 22), e a presença de um tumor misto de células germinativas 
foi encontrado em 1 paciente (20). Em 53,5\% dos pacientes foi identificado útero e trompa uterina em pelo menos um lado. Os derivados wolffianos foram detectados em $57 \%$ dos pacientes. Nos pacientes 17 e 19 os testículos viáveis foram preservados (realizado orquipexia bilateral no caso 17 e unilateral no caso 19), visto que mantidos na bolsa escrotal os mesmos podem ser examinados periodicamente e avaliados quanto à possibilidade de malignização, e ao mesmo tempo podemos preservar sua função, mesmo que parcial.

Tabela 6 - Anatomopatológico de pacientes com DG parcial 46,XY

\begin{tabular}{ll}
\hline Anatomopatológico (AP) & Resultados / número de pacientes \\
\hline & Disgenéticas bilaterais: 6 / +tumor: 3 \\
Gônadas & 1 disg. + 1 ausente: 6 / \\
& Test. viáveis preservados: 2 \\
& Ausentes bilaterais: 5 (ñ disponível: 6) \\
Derivados Müllerianos no AP & Presentes: 18 \\
(útero e tuba uterina) & Ausentes: 6 \\
& (Material não disponível: 4) \\
Derivados Wolffianos no AP & Presentes: 16 \\
& Ausentes: 7 \\
\hline
\end{tabular}




\subsubsection{Aspectos citogenéticos}

Não foi identificada nenhuma anomalia cromossômica nos 41 pacientes estudados. A análise citogenética com bandamento $G$ de 20-50 metáfases descartou a presença de mosaicismo ou qualquer outra aberração cromossômica nesta casuística.

\subsection{Grupo II - Pacientes com DDG 46,XX}

\subsubsection{Aspectos clínicos}

A idade cronológica do início da avaliação das pacientes com DDG 46, XX variou entre a $2^{\mathrm{a}}$ e a $3^{\mathrm{a}}$ década, com uma média de 18,6 anos (Tabela 7 ). A procura tardia por avaliação médica ocorreu porque os sintomas mais prevalentes surgiram no período da puberdade, que foram amenorréia primária (17 pacientes) e ausência do desenvolvimento de mamas. (15 pacientes). As pacientes que apresentaram amenorréia primária foram classificadas como portadoras de disgenesia gonadal pura (DG 46, XX). Duas pacientes com amenorréia primária apresentaram telarca, sugerindo função ovariana presente, porém não o suficiente para desencadear a menarca (casos 44 e 55). Duas pacientes apresentaram menarca, porém na paciente 52 a menarca ocorreu aos 18 anos, os ciclos menstruais foram irregulares desde o início, e aos 20 anos houve a parada completa da menstruação. No caso 59, a menarca 
ocorreu aos 15 anos (também tardia), os ciclos menstruais mantiveram-se irregulares até os 20 anos (períodos de até 7 meses sem ciclar), e aos 20 anos a paciente começou a tomar contraceptivos orais, não apresentando mais ciclos espontâneos. Dois anos depois, interrompendo o uso dos contraceptivos orais, os ciclos menstruais foram interrompidos, com dosagens de gonadotrofinas séricas elevadas. Essas pacientes foram classificadas como portadoras de falência ovariana prematura.

Tabela 7 - Dados clínicos das pacientes com DDG 46,XX

\begin{tabular}{ll}
\hline Dados clínicos & Resultados / número de pacientes \\
\hline Quadro clínico inicial & Ausência de telarca e menarca: 15 \\
& Ausência de menarca: 2 \\
\hline Idade da $1^{\text {a }}$ avaliação & Amenorréia secundária: 2 \\
\hline Pais consanguíneos & $1^{\text {a }}$ e $2^{\text {a década: } 15}$ \\
\hline Casos familiais & $3^{\text {a }}$ década: 4 \\
Doenças associadas & Sim: 9 (6 famílias) / Não: 10 (8 famílias) \\
\hline Us pélvico & 11 (6 famílias) \\
\hline
\end{tabular}

Uma paciente apresentou distúrbio da audição: a paciente 52 apresentava uma forma branda de disfunção auditiva, com hipoacusia bilateral neurossensorial, diagnosticada já na vida adulta.

A incidência de consangüinidade entre os pais foi alta nesse grupo $(47,3 \%)$, principalmente entre os grupos familiares $(63,3 \%)$. Outras doenças foram associadas às pacientes, como hipotireoidismo primário, forma leve 
(foi diagnosticado na vida adulta, sem alteração importante do desenvolvimento neuropsicomotor das pacientes), presente em duas irmãs (caso 50 e 51); eflúvio telógeno crônico, presente na paciente 58. A paciente 48 (irmã da paciente 49) apresenta ceratocone e doença de Wilson, ambas as doenças de caráter genético. De forma interessante, sua irmã não apresenta nenhuma das duas doenças, nem seus pais ou parentes próximos. Três pacientes (casos 42, 43 e 57) apresentam atraso do desenvolvimento neuropsicomotor, sendo o caso 57 associado à epilepsia, mas não apresentam distúrbio auditivo (não caracterizando, portanto, a síndrome de Perrault). Por fim, uma paciente (caso 54) apresenta uma alteração congênita na mão direita (agenesia das falanges do $3^{\circ}$ quirodáctilo e fusão dos $3^{\circ}$ e $4^{\circ}$ hemi-metacarpos, com alargamento da base do $2^{\circ}$ metacarpo), também presente no seu pai e no seu avô paterno.

\subsubsection{Aspectos hormonais}

As dosagens de gonadotrofinas, LH e FSH, apresentaram concentrações elevadas com predomínio do FSH, compatíveis com o diagnóstico de hipogonadismo hipergonadotrófico em todas as pacientes com DDG 46, XX, exceto em uma paciente (caso 45), que uma foi avaliada no período pré-puberal (Tabela 8). Todas as pacientes tinham nível basal de estrogênio baixo, com exceção das pacientes 47 e 55, sendo que esta última curiosamente também apresentou telarca sem uso de hormônios, mas não apresentou menarca até os 30 anos de idade. 
Tabela 8 - Dados hormonais das pacientes com DDG 46,XX

\begin{tabular}{ll}
\hline Dados clínicos e hormonais & Resultados/ número de pacientes \\
\hline LH e FSH & Pré-púbere: 1 / Elevado: 18 \\
E $_{2}$ inicial & $<35 \mathrm{pg} / \mathrm{mL}: 17$ / $>35 \mathrm{pg} / \mathrm{mL}: 2$ \\
\hline
\end{tabular}

\subsubsection{Aspectos ultrassonográficos}

Todas as pacientes submetidas a US pélvico antes do início do tratamento hormonal apresentaram útero hipoplásico, com exceção do caso 52, que apresentava apenas útero reduzido de tamanho em relação ao útero adulto. Os ovários não foram visualizados em 8 pacientes, e em 6 pacientes eles encontravam-se com dimensões reduzidas. Apenas duas pacientes apresentavam ovários de tamanhos normais no $1^{\circ}$ ultra-som (casos 52 e 58).

\subsubsection{Aspectos imunológicos}

Na pesquisa da história familiar, apenas uma paciente possuía dado positivo (mãe portadora de lúpus); essa paciente (caso 52), no entanto, apresentava auto-anticorpos negativos (anti-mitocondrial, fatores antinucleares, anti-músculo liso, anti-citosol hepático, fator reumatóide, fatores anti-nucleares), além de anticorpos anti-tireoglobulina e antitireoperoxidase também negativos. Doze das 19 pacientes apresentaram o anticorpo anti-célula esteroidal negativo. Apenas a paciente 58 dosou o anticorpo anti-adrenal, devido a sua alopécia (que estava em investigação), também negativo. 


\subsubsection{Aspectos histopatológicos}

Nenhuma paciente foi submetida à biópsia de gônadas, por ser um procedimento invasivo e por não ter havido necessidade na terapêutica.

\subsubsection{Aspectos citogenéticos}

Não foi identificada nenhuma anomalia cromossômica nos 19 pacientes estudados. A análise citogenética com bandamento $G$ de 20-50 metáfases descartou a presença de mosaicismo ou qualquer outra aberração cromossômica nesta casuística.

\subsection{Avaliação molecular}

\subsubsection{Gene CBX2}

\section{Grupo I - Pacientes com DDG 46,XY}

Diversas variantes alélicas foram identificadas ao longo do gene CBX2 (Figura 6, abaixo, e Tabela 23, no Anexo D). 


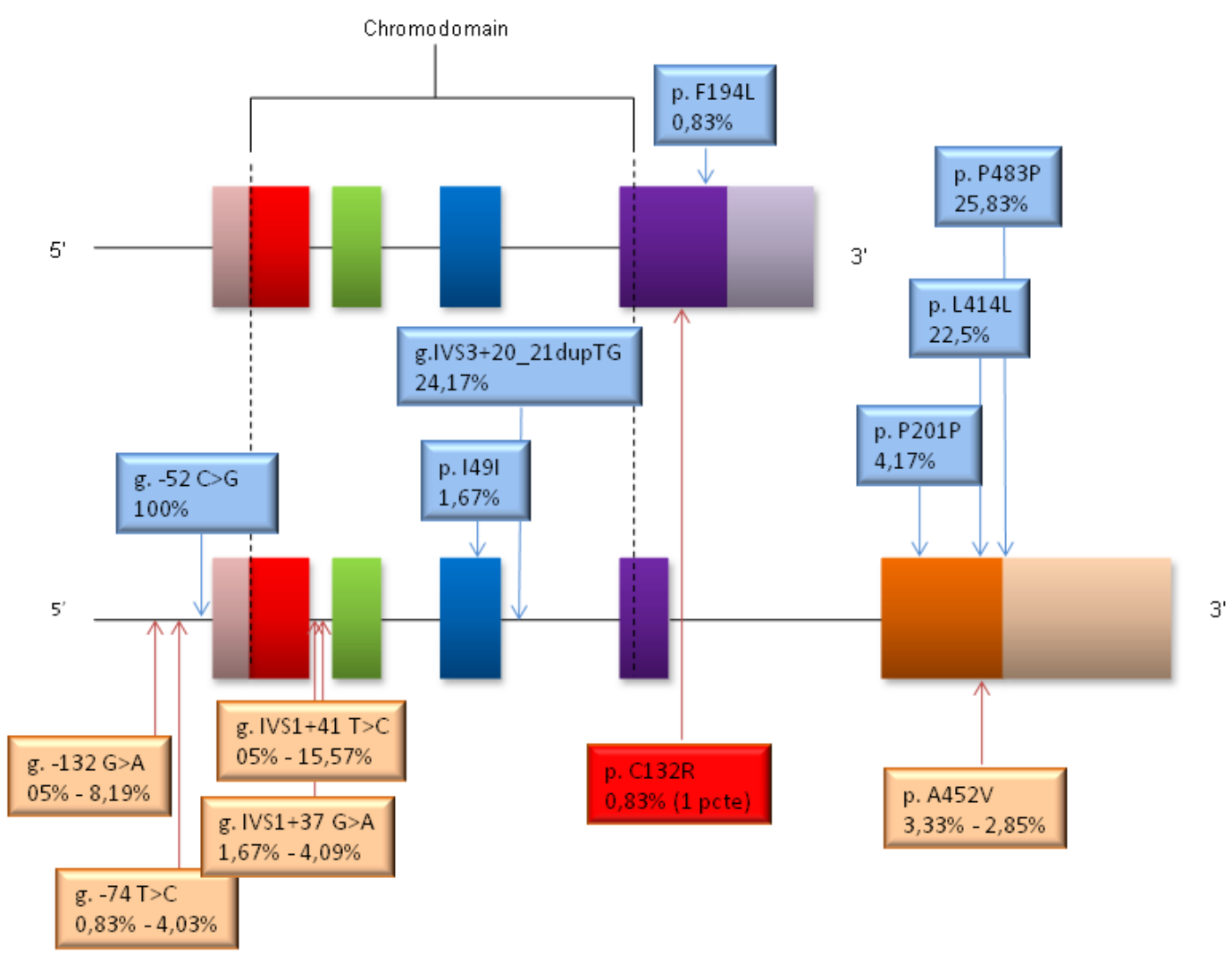

Figura 6. Gene CBX2 e variantes alélicas encontradas nos pacientes estudados. Em azul, variantes já descritas pela literatura (frequência encontrada nos pacientes). Em laranja, variantes não descritas pela literatura previamente, mas encontradas na população normal estudada (descrito a freqüência alélica encontrada em pacientes e em controles normais, respectivamente). Em vermelho, alteração não descrita pela literatura e que não foi encontrada no estudo de 100 indivíduos normais

Na região 5' não traduzida, uma variante alélica já descrita como polimorfismo foi encontrada em todos os pacientes, todos em homozigose (g.-52 $C>G)^{30}$. Ainda na região 5' não traduzida, duas outras variantes alélicas não descritas na literatura também foram identificadas: g.-132 G>A e g.-74T>C, em dois e um paciente, respectivamente, não relacionados, ambas em heterozigose. Para avaliar a importância dessas alterações nos pacientes, indivíduos normais $(X X$ e $X Y)$ foram estudados. Assim, para a variante g.-132 G>A, 61 indivíduos normais foram estudados (122 alelos), e a mesma alteração foi encontrada em oito indivíduos, 6 em heterozigose e 2 
em homozigose, (total de 10 alelos), resultando numa freqüência de 8,19\%. Em relação à variante g.-74 T>C, 62 indivíduos normais foram estudados (124 alelos), e a mesma alteração foi encontrada em 5 indivíduos, todos em heterozigose (5 alelos), resultando numa freqüência de 4,03\%.

No intron um, a variante ainda não descrita g.IVS1+41 T>C foi encontrada em três pacientes não relacionados, em heterozigose. Estudamos 61 indivíduos normais (122 alelos), e foi encontrada a mesma alteração em 13 indivíduos, sendo 7 em heterozigose e 6 em homozigose (19 alelos), resultando numa freqüência de 15,57\%.

No exon três, o polimorfismo já descrito p.I49l $(g .147 \mathrm{C}>\mathrm{T})^{30}$ foi encontrado em um paciente, em heterozigose. No intron três, a duplicação das bases +20 e +21 (g.IVS3+20_21dupTG) já descrita na literatura ${ }^{30}$ foi encontrada em 14 pacientes, estando em homozigose em 3 pacientes e em heterozigose nos 11 pacientes restantes.

No exon 4 do transcrito 1 (de 4 exons), foram encontradas duas alterações. A variante p.F194L (g.582 C>G) foi encontrada em apenas 1 paciente, mas já foi descrita na literatura como polimorfismo. A variante p.C132R (g.394 T>C), encontrada também em apenas um paciente, não havia sido descrita anteriormente, portanto foi realizado o estudo em controles normais. Para tanto, utilizamos a técnica de digestão enzimática por enzima de restrição. O estudo em 100 controles normais (200 alelos) não encontrou a variante em nenhum indivíduo estudado.

No exon cinco, três polimorfismos já descritos ${ }^{30}$ foram identificados: p.P201P (g.603 C>T) em quatro pacientes, p.L414L (g.1242 G>A) em 17 
pacientes e p.P483P (g. 1449 G>A) em 21 pacientes (todos em heterozigose). A variante alélica p.A452V (g. 1356 C>T), ainda não descrita, foi encontrada em quatro pacientes (em heterozigose), curiosamente associada aos polimorfismos p.P201P e p.P483P em todos os pacientes encontrados, e ao polimorfismo p.L414L em dois pacientes. Foram estudados 105 indivíduos normais (210 alelos), e encontrada a mesma alteração em 6 indivíduos, todos em heterozigose (6 alelos), totalizando a freqüência de 2,85\%.

\subsubsection{Grupo II - Pacientes com DDG 46,XX}

Em todas as pacientes $\mathrm{XX}$, o mesmo polimorfismo em homozigose na região 5' não traduzida foi encontrado (g.-52 C>G) (Figura 6, acima, e Tabela 23, no anexo D). A variante g.-132 G>A foi encontrada em quatro pacientes (em heterozigose), sendo uma pertencente ao grupo familiar $n^{\circ} 6$, duas pertencentes ao grupo familiar $n^{\circ} 9$ e uma com DDG 46,XX esporádica. Duas alterações em heterozigose foram identificadas no intron um: g.IVS1+37, encontrada em 2 irmãs (grupo familiar $n^{\circ} 9$ ), e g.IVS+41, encontrada em três pacientes não relacionadas, uma pertencente ao grupo familiar $n^{0} 6$ (a mesma paciente com a variante g.-132 G>A), uma pertencente ao grupo familiar $n^{\circ} 9$ (caso 48) e uma com DDG esporádica (a mesma paciente com a alteração g.-132 G>A, caso 59). A variante g.IVS1+37 foi estudada em 61 indivíduos normais (122 alelos), e foi encontrada em quatro indivíduos (três em heterozigose e um em homozigose - cinco alelos), totalizando uma freqüência de 4,09\%. 
A alteração p.I49I foi encontrada em uma paciente, em heterozigose (caso 43, família 6), e a variante g.IVS3+20_21dupTG foi encontrada em 11 pacientes (10 em heterozigose e um em homozigose).

No exon cinco, apenas os polimorfismos já descritos foram encontrados, todos em heterozigose. A variante p.L414L foi encontrada em 10 pacientes; já a alteração p.P483P foi encontrada em 10 pacientes; a variante p.P201P foi identificada em apenas uma paciente (caso 48, família 9), e a outra alteração (p.A452V) não foi encontrada nas pacientes XX.

\subsection{Gene TCF21}

\subsubsection{Grupo I - Pacientes com DDG 46,XY}

$\mathrm{Na}$ análise do seqüenciamento do gene TCF21 foi encontrado uma variante alélica no exon 1 (p.G22V / g.65 G>T) em 2 pacientes não relacionados (em heterozigose), ambos com DGP (casos 29 e 41). O estudo em 103 indivíduos normais identificou a mesma alteração em três indivíduos (em heterozigose), resultando numa freqüência alélica de 1,45\%.

\subsubsection{Grupo II - Pacientes com DDG 46, XX}

Nesse grupo, a variante alélica p.G22V foi encontrada em três pacientes, duas irmãs pertencentes ao grupo familiar $n^{0} 6$ e uma paciente com DDG esporádica (caso 56). 


\subsection{Gene $\mathrm{DHH}$}

\subsubsection{Grupo I - Pacientes com DDG 46,XY}

A análise do gene $\mathrm{DHH}$ teve como resultado uma nova variante alélica no exon dois, em um paciente com DG completa (caso 2), onde não há troca de aminoácido (p.H181H / g.543 C>T), e uma alteração intrônica em um paciente com DG completa (caso 1), em heterozigose (g.IVS $2+29$ G > A) (Figura 7).

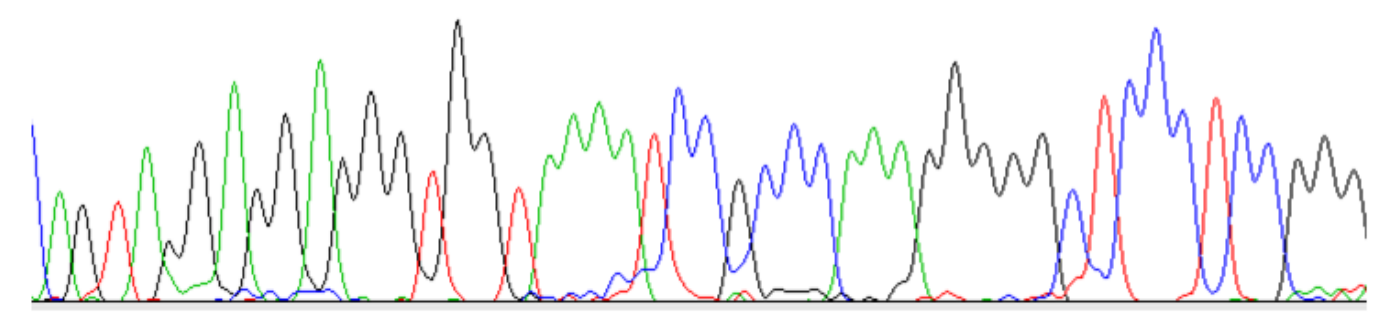

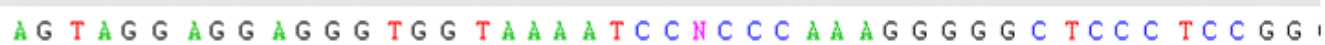

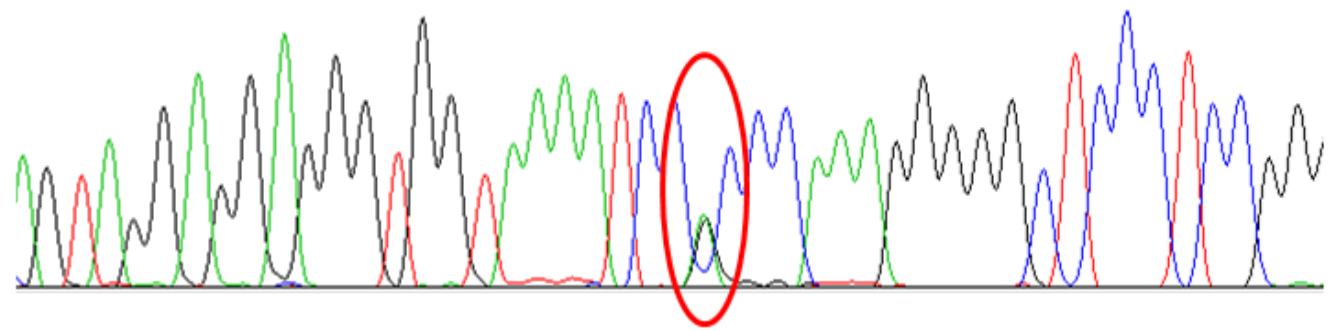

Figura 7. Gene $\mathrm{DHH}$, intron 2

Linha superior: controle normal;

Linha inferior: paciente com a alteração g.IVS 2 + 29 G > A 
A análise do seqüenciamento dos indivíduos normais (todos homens) mostrou as seguintes freqüências alélicas, descritas a seguir:

- A alteração no exon dois p.H181H foi encontrada nesta população de 103 controles normais em uma freqüência alélica de 0,97\% (um indivíduo).

- A alteração intrônica encontrada em heterozigose g.IVS2 +29G>A não foi encontrada no estudo dos 180 controles normais (360 alelos).

Dando seguimento ao estudo da alteração intrônica, foi estudada a mãe da paciente (DNA do pai não disponível), e foi encontrada a mesma alteração em heterozigose.

Para análise da alteração intrônica g.IVS $2+29$ G > A, decidimos inicialmente fazer o estudo do RNA da gônada do paciente (testículo), uma vez que possuíamos uma amostra da mesma congelada em nitrogênio líquido. A amostra do paciente foi comparada a dois controles: uma amostra constituída por um pool de testículos normais e uma segunda amostra obtida através da extração e amplificação do cDNA do testículo de um paciente sabidamente portador de disgenesia gonadal 46,XY, mas sem a mutação IVS $2+29 \mathrm{G}>\mathrm{A}$.

Como resultado, observamos que a região entre o exon 2 e 3 do gene DHH foi amplificada com sucesso no pool de testículos normais e em menor intensidade na amostra do paciente com a mutação. Foi realizado o seqüenciamento direto da amostra e visto que a sequência da região do cDNA (exon 2/exon3) manteve-se intacta. O cDNA não foi amplificado na 
amostra do paciente sem a mutação. As PCRs dos outros genes apresentaram padrões de expressão diversos (o cDNA do $A M H$ foi amplificado somente no pool de testículos normais, e o cDNA do AR foi amplificado em todas as amostras).

\subsection{Gene FOXL2}

\subsubsection{Grupo II - Pacientes com DDG 46,XX}

$\mathrm{Na}$ análise do seqüenciamento do gene FOXL2 foram encontrados três variantes alélicas: uma alteração em heterozigose, já descrita anteriormente ${ }^{54}$, encontrada em duas pacientes não relacionadas (p.A179G / g.536 C>G, casos 51 e 58); uma outra alteração em heterozigose, também já descrita ${ }^{70}$, encontrada nas mesmas duas pacientes que apresentam a variante anterior (p.F167F / g.501 C>T), em cuja tradução não há troca de aminoácidos; e uma alteração, em homozigose, não descrita na literatura anteriormente, encontrada em uma das duas pacientes acima citadas (p.A181A / g.543 C>T, caso 58), porém também silenciosa, não havendo troca de aminoácidos. Foi realizado o estudo de 103 controles normais $(46, X X)$ das três variantes encontradas. No estudo da variante ainda não descrita pela literatura (p.A181A / g.543 C>T), nenhum dos controles normais apresentava a alteração. Em relação às outras duas variantes, apesar de já descritas pela literatura, vale ressaltar um dado interessante: estas foram descritas como presentes em desequilíbrio de ligação, por 
serem encontradas sempre concomitantemente ${ }^{54}$. Em nosso estudo de controles normais, no entanto, elas foram encontradas separadamente, divergindo, portanto, da hipótese de que elas seriam encontradas apenas em desequilíbrio de ligação (Figura 8).
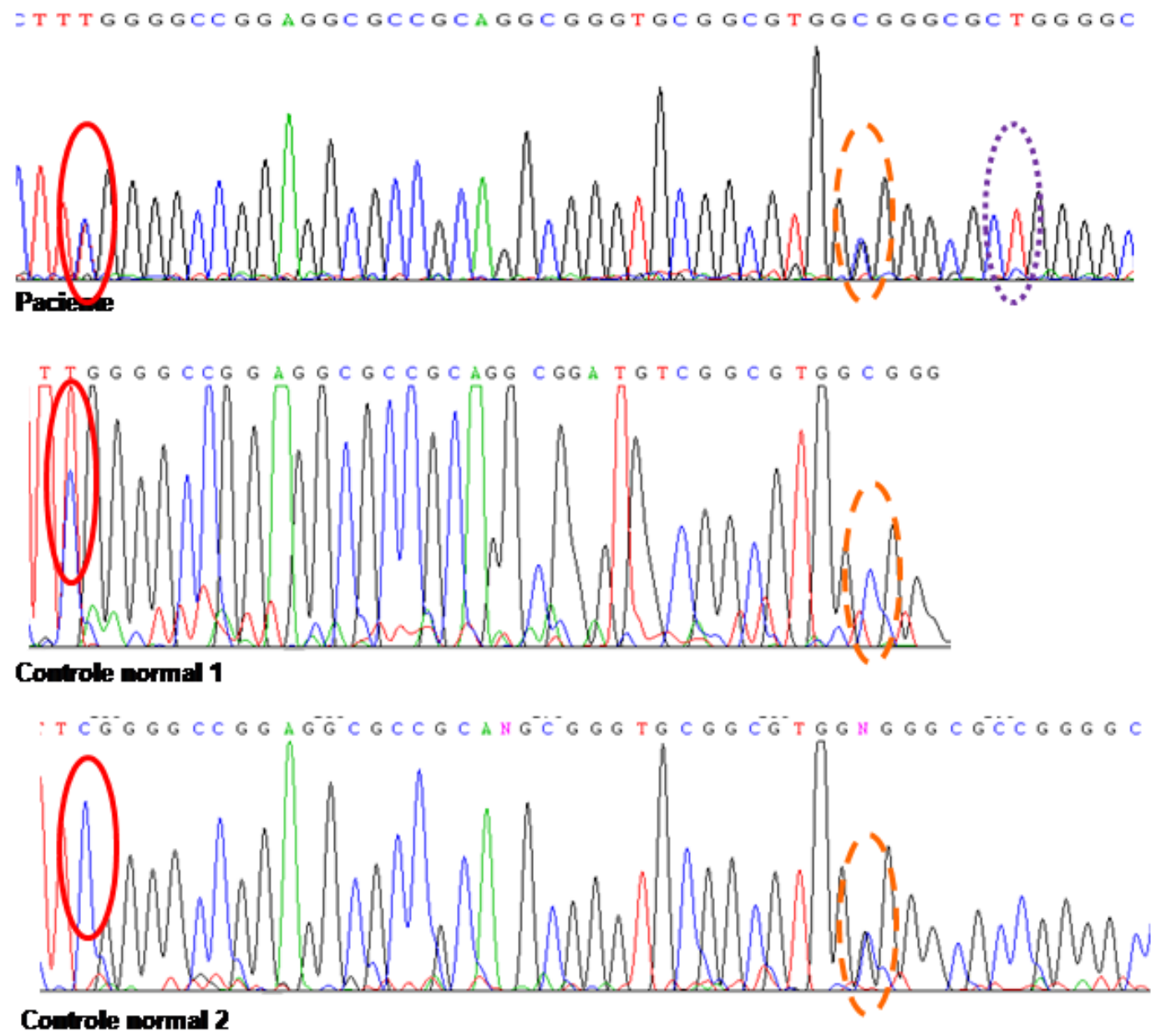

Figura 8. Paciente 58 e suas três variantes. Em vermelho, p.F167F; em tracejado laranja, p.A179G e em pontilhado roxo, p.A181A. Abaixo, dois controles normais mostrando que as variantes p.F167F e p.A179G não foram encontradas no mesmo indivíduo 
5 Discussão 


\subsection{Grupo I - Pacientes com DDG 46,XY}

\subsubsection{Aspectos clínicos}

A idade cronológica no início da avaliação destes pacientes variou de alguns dias de vida, principalmente nos casos de genitália ambígua, até tardiamente na vida adulta. As pacientes portadoras de disgenesia gonadal forma completa (DGC), por apresentarem genitália feminina normal, somente procuraram a avaliação médica mais tardiamente. O sintoma mais prevalente encontrado foi amenorréia primária, presente em todas as pacientes com este diagnóstico, como descrito na literatura ${ }^{83}$. Observamos a presença de mamas desenvolvidas em duas pacientes. Como laboratorialmente elas apresentavam hipoestrogenismo, é difícil explicar o desenvolvimento de telarca sem o uso de estrogênio exógeno. Ainda devemos considerar a hipótese de ter havido um erro no exame físico. Como o caso 3 veio ao nosso serviço apenas com 24 anos e o caso 8 veio encaminhada de outro serviço e nós não a examinamos (Fortaleza), levantamos a hipótese de que essas pacientes teriam recebido estrógeno por outro médico antes da nossa avaliação diagnóstica (ou ainda, no caso 8, foi confundido ao exame lipomastia com mama). 
Os casos de disgenesia gonadal parcial (DGP) foram diagnosticados mais precocemente do que o diagnóstico da forma completa, devido a presença de ambiguidade genital. No entanto, quatro pacientes com DGP, surpreendentemente, somente foram diagnosticados na $3^{\mathrm{a}}$ e $4^{\mathrm{a}}$ décadas de vida, apesar do grau de ambigüidade da genitália externa; este atraso no diagnóstico ocorreu provavelmente pelas condições socioeconômicas precárias.

A presença do seio urogenital foi identificada em $39,2 \%$ dos pacientes com DGP. A formação de seio urogenital acontece muito precocemente no processo de diferenciação sexual, estando concluído completamente em torno da $12^{\mathrm{a}}$ a $14^{\mathrm{a}}$ semana de gestação ${ }^{84}$. Este dado sugere que o comprometimento do desenvolvimento gonadal nestes pacientes ocorreu por volta deste período.

\subsubsection{Aspectos hormonais}

Todas as pacientes apresentaram achados de hipogonadismo hipergonadotrófico. Cinco pacientes com DGP, no entanto, apresentaram resposta ao hCG. Estes dados sugerem um comprometimento parcial das células de Leydig, que permitiram uma virilização parcial da genitália externa.

\subsubsection{Aspectos histológicos}

Todas as pacientes gonadectomizadas em nosso serviço apresentaram gônadas disgenéticas, em fita. Em todas as pacientes foi 
detectada a presença de útero e as trompas uterinas foram identificadas em $63,3 \%$ das pacientes e não descritas no exame anatomopatológico em dois casos. A ausência de regressão dos derivados müllerianos sugere o comprometimento das células de Sertoli que é responsável pela síntese do AMH. A presença de remanescentes de derivados wolffianos em três pacientes e a presença de epidídimo em apenas um caso também confirmam a regressão dos derivados wolffianos na maioria das pacientes devido à ausência da produção de andrógenos pelas células de Leydig, que têm um papel crítico na estabilização dos ductos de Wolff. Essa pouca diversidade de fenótipo está de acordo com a literatura, onde os pacientes com DG completa apresentam um grau muito pequeno de virilização associado a um mínimo ou ausente funcionamento das células de Sertoli ${ }^{83}$.

Nos pacientes com DGP, observamos a associação de gonadoblastoma e de tumor misto de células germinativas à gônada disgenética. Na literatura, o tumor mais comum associado à disgenesia gonadal é o gonadoblastoma ${ }^{83}$. Cools e colaboradores descreveram uma incidência de 35\% de tumor de células germinativas em uma coorte de 43 pacientes com disgenesia gonadal ${ }^{85}$. A identificação de útero e trompa uterina em $53,5 \%$ dos pacientes e de derivados wolffianos em $57 \%$ confirma o comprometimento das linhagens celulares de Sertoli, pela não regressão completa dos derivados müllerianos, e de Leydig pela não estabilização dos ductos wolffianos, que se apresentam em graus variados nestes pacientes. Como dado interessante, notamos que a presença de útero nos pacientes (considerando os achados ultrassonográficos e anatomopatológicos) com 
gônadas disgenéticas bilaterais foi maior $(76,9 \%)$ do que nos pacientes cuja gônada não foi encontrada em um dos dois lados ou bilateralmente $(33,3 \%)$. Por outro lado, a presença de derivados wolffianos foi menor nos pacientes com gônadas disgenéticas bilaterais $(38,4 \%)$ em relação aos pacientes com ausência de uma ou ambas as gônadas (60\%). Isto pode significar que as gônadas disgenéticas bilaterais tiveram menos função tanto das células de Leydig quanto das células de Sertoli do que as gônadas que regrediram, e que estas regrediram após o período crítico de produção de testosterona e hormônio anti-mülleriano (sendo que o fenótipo desses pacientes variou de acordo com a época da regressão). Na literatura, o fenótipo dos indivíduos

portadores de DGP também é muito variável, e Lopez-Lopez e colaboradores associaram essa variabilidade à provável variabilidade também na causa genética desse distúrbio ${ }^{86}$.

\subsection{Grupo II - Pacientes com DDG $46, X X$}

\subsubsection{Aspectos clínicos}

Uma paciente apresentava hipoacusia bilateral neurossensorial, diagnosticada já na vida adulta. A disgenesia gonadal associada à alteração auditiva neurossensorial compõe o quadro clínico da Síndrome de Perrault, descrito por Perrault e colaboradores em $1951^{87}$. Além desses distúrbios, alterações no sistema nervoso central podem estar presentes, como retardo 
mental, ataxia, coréia, dentre outros ${ }^{13}$. Em pacientes do sexo masculino, a síndrome apresenta as mesmas características, com exceção da alteração gonadal. O grau de severidade do defeito auditivo pode variar de leve até profunda surdez. Analogamente, a disgenesia ovariana pode apresentar-se precocemente com amenorréia primária, ou de forma mais branda e tardia, causando amenorréia secundária. Sendo assim, a paciente 52 pode se tratar também de uma mulher portadora da Síndrome de Perrault, porém apresentando uma forma mais leve (talvez uma mutação causando uma perda parcial de função da proteína).

Observamos uma alta incidência de consangüinidade presente entre os pais das pacientes; isto fortalece a idéia de que o distúrbio gonadal seja proveniente de uma alteração genética.

Outras doenças foram associadas às pacientes: o eflúvio telógeno crônico, presente na paciente 58, é uma forma de alopécia não cicatricial que apresenta etiologias diversas, dentre elas o hipoestrogenismo, a hipovitaminose, stress, dentre outros, mas não apresenta etiologia autoimune. O ceratocone é um distúrbio cuja herança pode estar ligada ao gene VSX1, encontrado no locus 20p11.2 (OMIM 605020), mas também pode estar relacionada aos cromossomos 2, 3 e 16 (OMIM 148300). Este distúrbio apresenta herança predominantemente autossômica dominante, com penetrância incompleta. A doença de Wilson, por sua vez, é um distúrbio cuja herança é autossômica recessiva, ligada ao gene $A T B 7 B$, encontrado no locus 13q14.3-q21.1 (OMIM 606882). Em nenhum dos dois distúrbios há relato de associação com disgenesia gonadal na literatura. 


\subsubsection{Aspectos hormonais}

Todas as pacientes apresentaram concentrações elevadas de gonadotrofinas com predomínio do FSH e nível basal de estrogênio baixo, compatíveis com hipogonadismo hipergonadotrófico. Duas pacientes tinham o estrógeno no limite inferior da normalidade para indivíduos adultos, sendo que uma inclusive desenvolveu mamas, sugerindo uma disfunção parcial de seus ovários, apesar de apresentarem amenorréia primária ${ }^{79}$.

\subsubsection{Aspectos ultrassonográficos}

Duas pacientes apresentavam ovários de tamanhos normais no $1^{\circ}$ ultra-som (casos 52 e 58). Isto pode significar que os ovários ainda tenham alguma função, como visto em algumas pacientes com POF, e que ainda esteja presente alguma reserva folicular, mantendo o volume ovariano normal e promovendo o crescimento uterino ${ }^{79}$.

\subsection{Análise molecular}

\subsubsection{Gene $C B X 2$}

Identificamos diversas variantes alélicas que também foram encontradas em controles normais, indicando que este gene é altamente 
polimórfico. Uma alteração, g.-52 C>G, já descrita na literatura previamente, foi encontrada em todos os pacientes, em homozigose, e em todos os controles normais, também em homozigose, indicando que esta variante provavelmente represente a seqüência normal em nossa população. As outras alterações foram encontradas em uma freqüência que variou de 0,83\% até 25,83\%, e alguns pacientes apresentaram mais de uma variante, chegando até 8 variantes nesse gene (quatro em um mesmo exon). Essas variantes, na sua maioria, foram encontradas em regiões não codificadoras (íntrons e região não traduzida 5'), e as alterações encontradas nos exons preservam o aminoácido, em sua grande maioria, com exceção de 3 alterações: a primeira um polimorfismo já conhecido (p.F194L); a segunda encontrada no fim do exon 5 (p.A452V), cuja freqüência em indivíduos normais foi a menor encontrada, 2,85\%. Essa seria uma alteração interessante, visto que no modelo animal estudado (camundongo) o knockout do gene foi realizado através da interrupção da leitura do DNA a partir do $5^{\circ}$ exon $^{19}$, e as mutações encontradas recentemente também eram localizadas neste exon ${ }^{32}$. A terceira variante, p.C132R, foi identificada em um paciente portador de DDG 46,XY (disgenesia gonadal parcial). Essa alteração é pouco conservada entre as espécies (Tabela 9), e é encontrada apenas no transcrito que apresenta 4 exons e em cujo $4^{\circ}$ exon é mais extenso; no entanto, há troca de aminoácido, e portanto será necessário o estudo funcional dessa alteração para avaliarmos a sua real importância. 
Tabela 9 - Variante p.C132R - Alinhamento com outras espécies

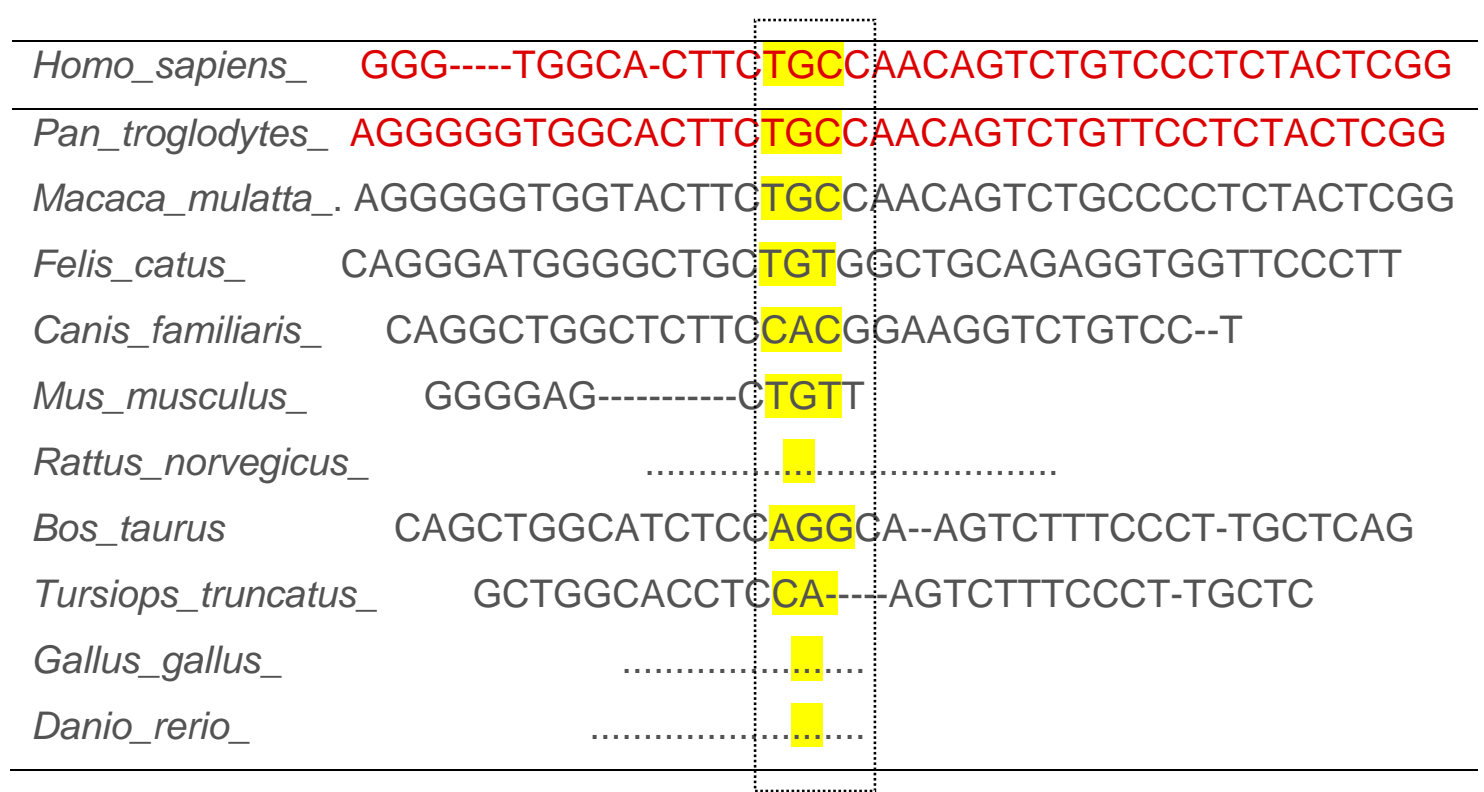

Sendo assim, vimos que o gene CBX2 parece ser uma rara causa de distúrbio do desenvolvimento gonadal nos seres humanos. Outros estudos sobre a sua participação na formação testicular e ovariana devem ser feitos para esclarecer sua importância nesse processo.

\subsubsection{Gene TCF21}

Esse gene, também com alterações importantes no modelo animal transgênico ${ }^{23}$, mostrou-se menos variável em relação ao gene $C B X 2$, porém não encontramos nenhuma alteração com uma freqüência alélica menor do que $1 \%$ em indivíduos normais. A alteração encontrada p.G22V está situada no início do exon 1, e não está inserida no domínio "basic helix-loop-helix" da proteína. Os pacientes 46,XY portadores da variante não são da mesma família (casos 29 e 41), sendo que o caso 29 é sobrinho do caso 28, e este 
paciente não apresenta a alteração. Nos pacientes $46, X X$ portadores da variante, 2 são irmãs (casos 42 e 43) e a outra paciente 46,XX não apresenta outro distúrbio associado, e também não apresenta outro parente afetado conhecido. Essa distribuição familiar nos pacientes 46,XY afasta a hipótese da variante p.G22V ser causadora do distúrbio gonadal. Apesar da freqüência alélica em indivíduos normais ser relativamente baixa (1,45\%), isto demonstra apenas que este gene é pouco polimórfico, mas não indica que possa ser importante para o desenvolvimento gonadal. Talvez o gene TCF21 deve ser de grande importância em processos vitais ao organismo, o que tornaria a vida inviável na presença de uma mutação com disfunção de sua proteína. Ao analisarmos o estudo com camundongos transgênicos, vemos que todos morrem logo após o nascimento por defeitos severos no pulmão, e que apresentam hipoplasia de rins e bexiga ${ }^{23}$. Inicialmente levantamos a hipótese de que talvez uma mutação pontual permitisse a sobrevivência do indivíduo, mas fosse capaz de interferir no desenvolvimento gonadal; talvez mesmo a mutação pontual seja importante para o desenvolvimento dos pulmões e/ou dos rins, tornando a vida inviável.

\subsubsection{Gene $D H H$}

Foram encontradas apenas duas variantes alélicas, ainda não descritas pela literatura. A primeira, uma alteração que não permite troca de aminoácidos, mas que foi encontrada em uma freqüência $<1 \%$ em 
indivíduos normais. Trata-se de uma freqüência baixa $(<1 \%)$, mas como não há troca de aminoácidos e foi encontrada em heterozigose, talvez não tenha um significado importante neste distúrbio. Isso pode significar apenas que talvez precisemos aumentar o número de controles normais estudados e que o gene é realmente pouco variável. No entanto, talvez seja necessário avaliar outros genes implicados na diferenciação testicular que possam estar envolvidos, em conjunto, com esta alteração encontrada no $\mathrm{DHH}$.

A segunda alteração, encontrada no caso 1, apesar de intrônica, não foi encontrada em indivíduos normais e segrega na família. Interessantemente ela está presente na mãe, que não teria nenhum distúrbio gonadal, visto que o $D H H$ não interfere no desenvolvimento ovariano ${ }^{88}$. Esta alteração, no entanto, não altera o sitio de splicing da extremidade 3' do exon 2, de acordo com o site http://www.fruitfly.org/ ${ }^{89}$, comprovado pela leitura do RNA extraído do testículo do paciente. O cDNA do $D H H$ não foi amplificado na amostra do paciente sem a mutação. Isto provavelmente aconteceu porque por se tratar de um testículo disgenético, talvez não houvesse célula de Sertoli suficiente para expressar o gene $D H H$. A expressão diminuída do gene $\mathrm{DHH}$ no paciente com a variante pode ser justificada pelo mesmo motivo, mas não podemos descartar que a expressão esteja diminuída devido à mutação. As diferentes expressões encontradas a partir da amplificação do cDNA dos outros genes ( $A M H$ e $A R$ ) mostraram que provavelmente elas também estão alteradas devido ao tecido ser disgenético. 


\subsubsection{Gene FOXL2}

Esse último gene, apesar de bastante conhecido, foi pouco estudado em nossa população, por isso a importância de nosso trabalho. Mesmo na literatura internacional, apesar de bastante estudado em falência ovariana prematura, pouco foi estudado especificamente em

disgenesia gonadal pura ${ }^{13,54,70}$. Nosso estudo, no entanto, demonstrou que esse gene também é uma rara causa de distúrbio do desenvolvimento ovariano na população brasileira, e que não parece estar ligado em pacientes com síndrome de Perrault, corroborando com dados prévios da literatura ${ }^{13}$. Duas das três variantes alélicas encontradas já haviam sido descritas na literatura, e a terceira variante encontrada não permite troca de aminoácidos, e não está localizada na região da sequência poliA (14 alaninas) encontrada na proteína FOXL2 (região onde foi encontrada uma deleção de 10 alaninas em uma paciente com POF $^{69,}{ }^{70}$ ) Estudos de mutação no FOXL2 em pacientes com BPES mostraram que não existe uma correlação precisa entre genótipo-fenótipo, mas proteínas truncadas antes da sequência poliA geralmente levam à BPES tipo I (com POF) e expansão da sequência poliA à BPES tipo II (sem POF). Por isso, Gersak e colaboradores sugeriram que uma deleção na sequência poliA, mantendo o resto da proteína intacta, poderia levar à POF, sem $\mathrm{BPES}^{69}$. Sendo assim, podemos dizer que a população brasileira está em concordância com a literatura mundial nesse aspecto ${ }^{70,71}$, e podemos dizer que mutações no FOXL2 não são a principal causa de DDG 46,XX. No entanto, vale ressaltar 
que em relação aos polimorfismos encontrados, nossa população controle diverge da população estudada pelos outros pesquisadores, uma vez que as variantes p.A179G e p.F167F não foram encontradas em desequilíbrio de ligação. 
6 Conclusões 
1- A apresentação fenotípica dos distúrbios do desenvolvimento gonadal é bastante variável, e parecem ser um espectro clínico de um mesmo distúrbio.

2- Identificamos seis novas variantes alélicas no $C B X 2$ (g.-132 G>A, g.-74 T>C, g.IVS1+41 T>C, g.IVS1+37G>A, p.A452V e p.C132R), e 7 polimorfismos já descritos (g.-52C>G, p.149I, g.IVS3+20_21dupTG, p.F194L, p.P201P, p.L414L e p.P483P). Estas variantes alélicas estão distribuídas ao longo de todo o gene. A associação destas variantes ocorreu de forma aleatória dentro dos grupos familiares. A alteração p.C132R não foi encontrada em controles normais, e há troca de aminoácidos; portanto ela pode ter importância no fenótipo do paciente afetado.

3- Identificamos uma nova variante alélica no TCF21 (p.G22V /g. 65 G>T). A associação desta variante ocorreu de forma aleatória dentro de uma mesma família. Não encontramos alterações nesse gene que poderiam justificar o distúrbio da determinação gonadal em nossos pacientes.

4- Identificamos duas alterações no gene $D H H$ distintas em dois pacientes com DDG 46,XY. A alteração p.H181H (g.543 C>T), apesar de baixa freqüência na população geral, parece ser um polimorfismo, visto que não há troca de aminoácidos. A variante intrônica g.IVS2+29 G>A, apesar de não encontrarmos em controles normais, não promove alteração no sítio de splicing, e, portanto não parece ter relação com o fenótipo do paciente em questão. 
5- Identificamos dois polimorfismos no gene FOXL2, p.F167F (g.501 C>T) e p.A179G (g.536 C>G), descritas previamente em desequilíbrio de ligação, mas não foram encontradas simultaneamente em nossos controles normais, onde se conclui que em nossa população esse fenômeno não ocorre. Além disso, descrevemos uma alteração que provavelmente deve se tratar de um novo polimorfismo, p.A181A (g.543 C>T), por não haver troca de aminoácidos, apesar de não encontrarmos em controles normais. 
$7 \quad$ Anexos 
Anexo A - Conferência Internacional sobre o Consenso em Intersexo

Em 2006, a Sociedade Européia de Endocrinologia Pediátrica e a Sociedade de Endocrinologia Pediátrica Americana (Lawson Wilkins), em colaboração com os participantes da Conferência Internacional do Consenso em Intersexo, revisaram e formularam propostas acerca da nomenclatura de pacientes com distúrbios do desenvolvimento sexual ${ }^{8}$. Avanços na identificação de causas genéticas desses distúrbios ressaltaram a preocupação em relação a problemas éticos e legais referentes aos termos usados em algumas situações. Nomes como "intersexo", "pseudohermafroditismo", "hermafroditismo", "sexo reverso" e diagnósticos baseados em gêneros contrários ao sexo social do indivíduo são particularmente controversos. Esses termos são considerados pejorativos pelos pacientes e podem ser confusos quando usados por médicos que desconhecem os distúrbios e pelos próprios pais e familiares dos indivíduos afetados.

Sendo assim, foram propostas mudanças nas terminologias utilizadas. Inicialmente, foi definido como "distúrbios do desenvolvimento sexual" (DDS) as condições congênitas cujo desenvolvimento do sexo cromossômico, gonadal ou anatômico é atípico. Em seqüência, alterações dos DDS de origem gonadal foram denominadas "distúrbios do desenvolvimento gonadal $46, X X$ ou $46, X Y "$ (DDG). Abaixo, segue a sugestão de classificação dos 
distúrbios do desenvolvimento gonadal baseado neste Consenso e adaptado por Mendonca et $\mathrm{al}^{9}$ (Tabela 10).

Tabela 10 - Classificação dos Distúrbios da Determinação Sexual (alterações do desenvolvimento gonadal)

\section{Distúrbios do desenvolvimento sexual (DDS) por} alterações do desenvolvimento gonadal

Agenesia gonadal

Disgenesia gonadal - formas completa e parcial

Síndrome da regressão testicular embrionária

Disgenesia gonadal associada a fenótipos sindrômicos 
Anexo B - Tabelas com os oligonucleotídeos e protocolos de PCR dos genes estudados

Tabela 11 - Seqüência dos oligonucleotídeos (primers) utilizados no estudo do gene CBX2

\begin{tabular}{|c|c|c|c|c|c|}
\hline Exon & Primer & Seqüência 5' $\rightarrow$ 3' & $\begin{array}{l}\text { Fragmento } \\
(\mathrm{pb})\end{array}$ & $\begin{array}{l}\text { Temperatura de } \\
\text { hibridização }\left({ }^{\circ} \mathrm{C}\right)\end{array}$ & $\begin{array}{l}\mathrm{N}^{\circ} \mathrm{de} \\
\text { ciclos }\end{array}$ \\
\hline $1-2$ & $\begin{array}{l}1-2 \mathrm{~F} \\
1-2 \mathrm{R}\end{array}$ & $\begin{array}{l}\text { aag tcc cta ggc acc tcc tc } \\
\text { cgt gta aac aaa ggg caa cc }\end{array}$ & 748 & 63 & 35 \\
\hline 3 & $\begin{array}{l}3 F \\
3 R\end{array}$ & $\begin{array}{l}\text { cct ggg ttt gga ctt tga ga } \\
\text { cag cac gac tcc aac cag }\end{array}$ & 284 & 56 & 35 \\
\hline 4 & $\begin{array}{l}4 \mathrm{~F} \\
4 \mathrm{R}\end{array}$ & $\begin{array}{l}\text { atg aaa tgg gat ggc tgg } t \\
\text { aga agg cca aag cac atc at }\end{array}$ & 848 & $58-60$ & 35 \\
\hline 5 & $\begin{array}{l}5 A F \\
5 A R\end{array}$ & $\begin{array}{l}\text { cac aac acc cgg cta att tt } \\
\text { gcc ttc ggg att ttg ctt }\end{array}$ & 815 & 60 & 35 \\
\hline 5 & $\begin{array}{l}5 B F \\
5 B R\end{array}$ & $\begin{array}{l}\text { gag ctc cat cgt gca cta ca } \\
\text { aga ctc ttg agg ggg ctt g }\end{array}$ & 937 & 58 & 35 \\
\hline
\end{tabular}

Protocolo das condições de PCR para amplificação do gene CBX2:

- Exon 1-2- (95 $\left.{ }^{\circ} \mathrm{C} 08 \mathrm{~min}\right),\left(97^{\circ} \mathrm{C} 01 \mathrm{~min} ; 63^{\circ} \mathrm{C} 30 \mathrm{seg} ; 72^{\circ} \mathrm{C} 1 \mathrm{~min}\right) 35$ ciclos; $72^{\circ} \mathrm{C} 10$ min. Para amplificação deste exon foi utilizado 2,5 $\mu \mathrm{L}$ de 10X PCRx Enhancer Solution (Invitrogen) para cada reação.

- Exon 3- $\left(95^{\circ} \mathrm{C} 08 \mathrm{~min}\right),\left(97^{\circ} \mathrm{C} 01 \mathrm{~min} ; 56^{\circ} \mathrm{C} 30 \mathrm{seg} ; 72^{\circ} \mathrm{C} 1 \mathrm{~min}\right) 35$ ciclos; $72^{\circ} \mathrm{C} 10 \mathrm{~min}$.

- Exon 4- $\left(95^{\circ} \mathrm{C} 08 \mathrm{~min}\right),\left(97^{\circ} \mathrm{C} 01 \mathrm{~min} ; 58-60^{\circ} \mathrm{C} 30 \mathrm{seg} ; 72^{\circ} \mathrm{C} 1 \mathrm{~min}\right) 35$ ciclos; $72^{\circ} \mathrm{C} 10 \mathrm{~min}$.

- Exon 5 - fragmento A- $\left(95^{\circ} \mathrm{C} 08 \mathrm{~min}\right),\left(97^{\circ} \mathrm{C} 01 \mathrm{~min} ; 60^{\circ} \mathrm{C} 30 \mathrm{seg}\right.$; $\left.72^{\circ} \mathrm{C} 1 \mathrm{~min}\right) 35$ ciclos; $72^{\circ} \mathrm{C} 10 \mathrm{~min}$.

- Exon 5 - fragmento B- $\left(95^{\circ} \mathrm{C} 08 \mathrm{~min}\right),\left(97^{\circ} \mathrm{C} 01 \mathrm{~min} ; 58^{\circ} \mathrm{C} 30 \mathrm{seg}\right.$; $\left.72^{\circ} \mathrm{C} 1 \mathrm{~min}\right) 35$ ciclos; $72^{\circ} \mathrm{C} 10 \mathrm{~min}$. 
Tabela 12 - Seqüência dos oligonucleotídeos (primers) utilizados no estudo do gene TCF21

\begin{tabular}{lllccc}
\hline Exon & Primer & Seqüência 5' $\rightarrow \mathbf{3}^{\prime}$ & $\begin{array}{c}\text { Fragmento } \\
(\mathbf{p b})\end{array}$ & $\begin{array}{c}\text { Temperatura de } \\
\text { hibridização }\left({ }^{\circ} \mathbf{C}\right)\end{array}$ & $\begin{array}{c}\mathbf{N}^{\circ} \mathbf{~ d e} \\
\text { ciclos }\end{array}$ \\
\hline 1 & $1 \mathrm{~F}$ & acc ctc ttc ctc gct ttc t & 646 & 59 & 35 \\
& $1 \mathrm{R}$ & cgg tgg tcg aga tgt gta a & & & \\
2 & $2 \mathrm{~F}$ & $\begin{array}{l}\text { cct ttc atc tca ggc ccc gag tcc } \\
\text { gtt ctc gcg ggg tgg gac ag }\end{array}$ & 303 & $70-71$ & 35 \\
\hline
\end{tabular}

\section{Protocolo das condições de PCR para amplificação do gene TCF21:}

- Exon 1- $\left(96^{\circ} \mathrm{C} 05 \mathrm{~min}\right) *,\left(96^{\circ} \mathrm{C} 45 \mathrm{seg} ; 59^{\circ} \mathrm{C} 45 \mathrm{seg} ; 72^{\circ} \mathrm{C} 45 \mathrm{seg}\right) 35$ ciclos; $72^{\circ} \mathrm{C} 10 \mathrm{~min}$.

- Exon 2- $\left(96^{\circ} \mathrm{C} 05 \mathrm{~min}\right) *,\left(96^{\circ} \mathrm{C} 45 \mathrm{seg} ; 70-71^{\circ} \mathrm{C} 45 \mathrm{seg} ; 72^{\circ} \mathrm{C} 45 \mathrm{seg}\right)$ 35 ciclos; $72^{\circ} \mathrm{C} 10 \mathrm{~min}$.

Tabela 13 - Seqüência dos oligonucleotídeos (primers) utilizados no estudo do gene $D H H$

\begin{tabular}{|c|c|c|c|c|c|}
\hline Exon & Primer & Seqüência 5' $\rightarrow$ 3' & $\begin{array}{l}\text { Fragmento } \\
\quad(p b)\end{array}$ & $\begin{array}{l}\text { Temperatura de } \\
\text { hibridização } \\
\left({ }^{\circ} \mathrm{C}\right)\end{array}$ & $\begin{array}{l}N^{\circ} \text { de } \\
\text { ciclos }\end{array}$ \\
\hline 1 & $1 \mathrm{~F}$ & aag agc tct agg gca ctc t & 491 & 56 & 35 \\
\hline 2 & $\begin{array}{l}1 \mathrm{R} \\
2 \mathrm{~F} \\
2 \mathrm{R}\end{array}$ & $\begin{array}{l}\text { gcc ata gga aaa cgg agg a } \\
\text { tgg gag ggg taa gag tag g } \\
\text { gac ggg tog ttt tca aca c }\end{array}$ & 496 & 58 & 35 \\
\hline 3 & $\begin{array}{l}\text { 3AF } \\
\text { 3AR }\end{array}$ & $\begin{array}{l}\text { ctt gat tca atc ctc cct gtg gtt g } \\
\text { ccc gcc ggg cgc cag cac cga gtc }\end{array}$ & 385 & 60 & 35 \\
\hline 3 & $\begin{array}{l}3 B F \\
3 B R\end{array}$ & $\begin{array}{l}\text { gct gtg gag acc gag tgg } \\
\text { cac agc ccc ata tct cag c }\end{array}$ & 499 & 64 & 35 \\
\hline
\end{tabular}

\section{Protocolo das condições de PCR para amplificação do gene $D H H$ :}

- Exon 1- (96 $\left.{ }^{\circ} \mathrm{C} 05 \mathrm{~min}\right),\left(96^{\circ} \mathrm{C} 01 \mathrm{~min} ; 56^{\circ} \mathrm{C} 1 \mathrm{~min} ; 72^{\circ} \mathrm{C} 1 \mathrm{~min}\right) 35$ ciclos; $72^{\circ} \mathrm{C} 10 \mathrm{~min}$.

- Exon 2- (96 $\left.{ }^{\circ} \mathrm{C} 05 \mathrm{~min}\right),\left(96^{\circ} \mathrm{C} 01 \mathrm{~min} ; 58^{\circ} \mathrm{C} 1 \mathrm{~min} ; 72^{\circ} \mathrm{C} 1 \mathrm{~min}\right) 35$ ciclos; $72^{\circ} \mathrm{C} 10 \mathrm{~min}$.

- Exon 3- fragmento - $\left(96^{\circ} \mathrm{C} 05 \mathrm{~min}\right),\left(96^{\circ} \mathrm{C} 01 \mathrm{~min} ; 60^{\circ} \mathrm{C} 1 \mathrm{~min} ; 72^{\circ} \mathrm{C}\right.$ 1 min) 35 ciclos; $72^{\circ} \mathrm{C} 10 \mathrm{~min}$. 
- $\quad$ Exon 3 - fragmento B - (96 $\left.{ }^{\circ} \mathrm{C} 05 \mathrm{~min}\right),\left(96^{\circ} \mathrm{C} 45 \mathrm{seg} ; 64^{\circ} \mathrm{C} 45 \mathrm{seg}\right.$; $\left.72^{\circ} \mathrm{C} 45 \mathrm{seg}\right) 35$ ciclos; $72^{\circ} \mathrm{C} 10 \mathrm{~min}$

Tabela 14 - Seqüência dos oligonucleotídeos (primers) utilizados no estudo do gene FOXL2

\begin{tabular}{|c|c|c|c|c|c|}
\hline Exon & Primer & Seqüência 5' $\rightarrow 3^{\prime}$ & $\begin{array}{l}\text { Fragmento } \\
(\mathrm{pb})\end{array}$ & $\begin{array}{l}\text { Temperatura de } \\
\text { hibridização }\left({ }^{\circ} \mathrm{C}\right)\end{array}$ & $\begin{array}{l}N^{\circ} \text { de } \\
\text { ciclos }\end{array}$ \\
\hline 1 & $\begin{array}{l}1 \mathrm{~F} \\
1 \mathrm{R}\end{array}$ & $\begin{array}{l}\text { gaa aag aaa acc cac caa gg } \\
\text { tcc aqc gtc cag tag ttg c }\end{array}$ & 700 & 60 & 35 \\
\hline 1 & $\begin{array}{l}2 \mathrm{~F} \\
2 \mathrm{R}\end{array}$ & $\begin{array}{l}\text { cct caa cga gtg ctt cat ca } \\
\text { gag cga cag gag ctt agg aa }\end{array}$ & 986 & 50 & 35 \\
\hline 1 & A & aca gtc aag gag cca gaa gg & 326 & Seqüência & \\
\hline
\end{tabular}

Protocolo das condições de PCR para amplificação do gene FOXL2:

- Exon 1- $1^{\circ}$ par $-96^{\circ} \mathrm{C} 08 \mathrm{~min},\left(94^{\circ} \mathrm{C} 1 \mathrm{~min} ; 60^{\circ} \mathrm{C} 1 \mathrm{~min} ; 72^{\circ} \mathrm{C} 1 \mathrm{~min}\right)$ 35 ciclos; $72^{\circ} \mathrm{C} 10 \mathrm{~min}$.

- Exon $1-2^{\circ}$ par $-95^{\circ} \mathrm{C} 08 \mathrm{~min},\left(97^{\circ} \mathrm{C} 1 \mathrm{~min} ; 50^{\circ} \mathrm{C} 1 \mathrm{~min} ; 72^{\circ} \mathrm{C} 1 \mathrm{~min}\right)$ 35 ciclos; $72^{\circ} \mathrm{C} 10$ min. Para amplificação deste exon foi utilizada Betaína, na concentração de 0,4 M.

Tabela 15 - Seqüência dos oligonucleotídeos (primers) utilizados no estudo do cDNA do gene $D H H$

\begin{tabular}{lllccc}
\hline Exon & Primer & Seqüência 5' $\rightarrow \mathbf{3}^{\prime}$ & $\begin{array}{c}\text { Fragmento } \\
(\mathbf{p b})\end{array}$ & $\begin{array}{c}\text { Temperatura de } \\
\text { hibridização }\left({ }^{\circ} \mathbf{C}\right)\end{array}$ & $\begin{array}{c}\mathbf{N}^{\circ} \text { de } \\
\text { ciclos }\end{array}$ \\
\hline 2 & $\mathrm{~F}$ & gtt gta agg agc ggg tga ac & 887 & 62 & 35 \\
3 & $\mathrm{R}$ & agg agc cga gag tac caa tg & & & \\
\hline
\end{tabular}

Protocolo das condições de PCR para amplificação do cDNA do gene $D H H:$

- $96^{\circ} \mathrm{C} 05 \mathrm{~min},\left(96^{\circ} \mathrm{C} 1 \mathrm{~min} ; 62^{\circ} \mathrm{C} 1 \mathrm{~min} ; 72^{\circ} \mathrm{C} 1 \mathrm{~min}\right) 35$ ciclos; $72^{\circ} \mathrm{C} 10$ $\min$. 
Tabela 16 - Seqüência dos oligonucleotídeos (primers) utilizados no estudo do cDNA dos genes $A M H$ e $A R$

\begin{tabular}{cccccc}
\hline Gene & Primer & \multicolumn{1}{c}{ Seqüência 5' $\rightarrow \mathbf{3}^{\prime}$} & $\begin{array}{c}\text { Fragmento } \\
(\mathbf{p b})\end{array}$ & $\begin{array}{c}\text { Temperatura de } \\
\text { hibridização }\left({ }^{\circ} \mathbf{C}\right)\end{array}$ & $\begin{array}{c}\mathbf{N}^{\circ} \text { de } \\
\text { ciclos }\end{array}$ \\
\hline AMH & F & cac ctg gag gaa gtg acc tg & 454 & 62 & 35 \\
& R & gtg gcg act cct cga gtt c & & & \\
AR 1/2 & F & cgc ctg ttg aac tct tct gag c & 427 & 60 & 40 \\
& R & gct gtg aag gtt gct gtt cct C & & & 40 \\
AR 3/4 & F & cac agg cta cct ggt cct gg & 414 & 60 & 40 \\
& R & ctg cct tac aca caa ctc ctt gg & & & \\
\hline
\end{tabular}

Protocolo das condições de PCR para amplificação do cDNA dos genes $A M H$ e $A R$ :

- $\mathrm{AMH}-95^{\circ} \mathrm{C} 05 \mathrm{~min},\left(95^{\circ} \mathrm{C} 30 \mathrm{~s} ; 62^{\circ} \mathrm{C} 30 \mathrm{~s} ; 72^{\circ} \mathrm{C} 30 \mathrm{~s}\right) 35$ ciclos; $72^{\circ} \mathrm{C}$ $10 \mathrm{~min}$.

- AR $1 / 2-98^{\circ} \mathrm{C} 05 \mathrm{~min},\left(98^{\circ} \mathrm{C} 30 \mathrm{~s} ; 60^{\circ} \mathrm{C} 30 \mathrm{~s} ; 72^{\circ} \mathrm{C} 30 \mathrm{~s}\right) 40$ ciclos; $72^{\circ} \mathrm{C} 10 \mathrm{~min}$.

- AR $3 / 4-98^{\circ} \mathrm{C} 05 \mathrm{~min},\left(98^{\circ} \mathrm{C} 30 \mathrm{~s} ; 60^{\circ} \mathrm{C} 30 \mathrm{~s} ; 72^{\circ} \mathrm{C} 30 \mathrm{~s}\right) 40$ ciclos; $72^{\circ} \mathrm{C} 10 \mathrm{~min}$ 
Anexo C - Tabelas com os dados clínicos, hormonais e anatomopatológicos dos pacientes estudados

Tabela 17 - Dados clínicos e hormonais dos pacientes com disgenesia gonadal completa 46, XY

\begin{tabular}{|c|c|c|c|c|c|c|c|c|c|}
\hline Caso & $\begin{array}{c}\text { Sexo } \\
\text { social }^{b}\end{array}$ & $\begin{array}{l}\text { Quadro clínico } \\
\text { inicial }^{\mathrm{c}, \mathrm{d}}\end{array}$ & $\begin{array}{c}\text { Idade } 1^{\mathrm{a}} \\
\text { avaliação }^{\mathrm{e}}\end{array}$ & $\begin{array}{c}\text { Pais } \\
\text { consangüíneos }\end{array}$ & $\begin{array}{l}\text { Genitália } \\
\text { externa }^{b}\end{array}$ & $\begin{array}{l}\mathrm{LH}^{\dagger} \\
\mathrm{UI} / \mathrm{L}\end{array}$ & $\begin{array}{l}\text { FSH }^{\dagger} \\
\text { UI/L }\end{array}$ & $\begin{array}{c}\text { T basal } \\
\text { ng/dL }\end{array}$ & $\begin{array}{c}\text { T após } h^{\prime} C^{f} \\
n g / d L\end{array}$ \\
\hline 1 & $\mathrm{~F}$ & Ausência de T e M & 16 & Não & $\mathrm{F}$ & $19,5^{\star}$ & $80,9 *$ & $<10$ & 21 \\
\hline 2 & $\mathrm{~F}$ & Ausência de T e M & 24 & Não & $\mathrm{F}$ & $22,6^{\star}$ & $64,6^{*}$ & 22 & 22 \\
\hline 3 & $\mathrm{~F}$ & Ausência de M & 24 & $\operatorname{Sim}$ & $\mathrm{F}$ & 9 & 41 & $<14$ & $N R^{\circ}$ \\
\hline 4 & $\mathrm{~F}$ & Ausência de T e M & 21 & Não & $\mathrm{F}$ & 11,58 & 38,3 & $N R^{\circ}$ & $N^{\circ}$ \\
\hline 5 & $\mathrm{~F}$ & Ausência de T e M & 23 & Não & $\mathrm{F}$ & 21 & 76 & 35 & $N R^{\circ}$ \\
\hline 6 & $\mathrm{~F}$ & Ausência de T e M & 22 & Não & $\mathrm{F}$ & 17,6 & 74,8 & $<14$ & $\mathrm{NR}^{\circ}$ \\
\hline 7 & $\mathrm{~F}$ & Ausência de T e M & 19 & $\operatorname{Sim}$ & $\mathrm{F}$ & 14,3 & 75,3 & 14 & $N R^{\circ}$ \\
\hline $8^{1}$ & $\mathrm{~F}$ & Ausência de M & 15,8 & Não & $\mathrm{F}$ & 27 & 5,5 & 11 & $N R^{\circ}$ \\
\hline $9^{1}$ & $\mathrm{~F}$ & Ausência de T e M & 11,1 & Não & $\mathrm{F}$ & 1,8 & 3,4 & $<10$ & $N R^{\circ}$ \\
\hline 10 & $\mathrm{~F}$ & Ausência de T e M & 20 & Não & $\mathrm{F}$ & 70 & 80 & $<10$ & $\mathrm{NR}^{\circ}$ \\
\hline 11 & $\mathrm{~F}$ & Ausência de T e M & 45 & Sim & $\mathrm{F}$ & $13,6^{*}$ & $56^{*}$ & 34 & $<14$ \\
\hline 12 & $\mathrm{~F}$ & Ausência de T e M & 16 & Não & $\mathrm{F}$ & 22,6 & 62,9 & 32 & $\mathrm{NR}^{\circ}$ \\
\hline \multirow[t]{5}{*}{$13^{5}$} & $\mathrm{~F}$ & Ausência de T e M & 25 & Sim & $\mathrm{F}$ & 43 & 97 & 14 & $\mathrm{NR}^{\circ}$ \\
\hline & & \multirow[t]{4}{*}{ Valores } & Normais & IFME* $^{*}$ & Crianças & $0,6-1,3^{*}$ & $1,0-3,1^{*}$ & & \\
\hline & & & & & Adultos & $1,4-9,2^{*}$ & $1,0-12^{\star}$ & & \\
\hline & & & & RIE & Crianças & $1,0-10$ & $1,0-10$ & $<30$ & $391 \pm 129$ \\
\hline & & & & & Adultos & $1,0-10$ & $1,0-10$ & $441-925$ & $1306 \pm 577$ \\
\hline
\end{tabular}

$\overline{1,5}$ casos familiares 1 e $5 ;{ }^{b}$ F-feminino; ${ }^{c, d}$ T-Telarca, M-menarca; ${ }^{e}$ anos; ${ }^{f}$ exames hormonais pré-operatórios; * IFME- método imunofluorométrico; RIE- método radioimunoensaio; $\mathrm{NR}^{\circ}$ - exame não realizado 
Tabela 18 - Genitais internos e exame anatomopatológico dos pacientes com disgenesia gonadal completa 46, XY

\begin{tabular}{|c|c|c|c|c|}
\hline Caso & US pélvico útero & AP: Gônadas ${ }^{b}$ & AP: Derivados Müllerianos ${ }^{b}$ & AP: Derivados Wolffianos ${ }^{b}$ \\
\hline 1 & Presente & Disgenéticas Bilaterais & Tubas uterinas bilaterais & Presentes $^{d}$ \\
\hline 2 & Presente & Disgenéticas Bilaterais & Tubas uterinas bilaterais & Ausentes \\
\hline 3 & Presente & Disgenéticas Bilaterais $^{c}$ & Tubas uterinas bilaterais & $\mathrm{E}^{\mathrm{e}}$ bilaterais \\
\hline 4 & Presente & Disgenéticas Bilaterais & Ausentes & $N D^{\#}$ \\
\hline 5 & Presente & Disgenéticas Bilaterais & Tubas uterinas bilaterais & Ausentes \\
\hline 6 & Presente & Disgenéticas Bilaterais & Tubas uterinas bilaterais & Ausentes \\
\hline 7 & Presente & Disgenéticas Bilaterais & Tubas uterinas bilaterais & Presentes $^{d}$ \\
\hline $8^{1}$ & Presente & $N^{\#}$ & $N D^{\#}$ & $\mathrm{ND}^{\#}$ \\
\hline $9^{1}$ & Presente & $N D^{\#}$ & $N D^{\#}$ & $N D^{\#}$ \\
\hline 10 & Presente & Disgenéticas Bilaterais & Ausentes & Ausentes \\
\hline 11 & Presente & Disgenéticas Bilaterais & Tubas uterinas bilaterais & Presentes $^{d}$ \\
\hline 12 & Presente & Ausentes & Tubas uterinas bilaterais & Ausentes \\
\hline $13^{5}$ & Presente & Ausentes & Tubas uterinas bilaterais & Ausentes \\
\hline
\end{tabular}

$\overline{1,5}$ casos familiares 1 e $5 ;{ }^{b}$ AP- Anatomopatológico; ${ }^{c}$ Presença de gonadoblastoma; ${ }^{\mathrm{d}}$ remanescentes wolffianos não diferenciados; $\mathrm{E}^{\mathrm{e}}$ - epidídimo; $\mathrm{ND}^{\#}$ - material não disponível 
Tabela 19 - Dados clínicos e hormonais dos pacientes com disgenesia gonadal parcial 46, XY

\begin{tabular}{|c|c|c|c|c|c|c|c|c|c|}
\hline Caso & $\begin{array}{l}\text { Sexo } \\
\text { social }^{c}\end{array}$ & Quadro clínico inicial & $\begin{array}{c}\text { Idade } 1^{a} \\
\text { avaliação }^{d}\end{array}$ & $\begin{array}{c}\text { Pais } \\
\text { consangüíneos }\end{array}$ & $\begin{array}{c}\text { Genitália } \\
\text { externa }\end{array}$ & $\begin{array}{l}\mathrm{LH}^{\mathrm{e}} \\
\mathrm{UI/L}\end{array}$ & $\begin{array}{c}\text { FSH } \\
\text { UI/L }\end{array}$ & $\begin{array}{c}\text { T } \text { basal }^{\mathrm{e}} \\
\text { ng/dL }\end{array}$ & $\begin{array}{c}\text { T após } \mathrm{hCG}^{\mathrm{e}} \\
\text { ng/dL }\end{array}$ \\
\hline $14^{2}$ & $\mathrm{~F}$ & Genitália ambígua ao nascimento & 10 & Não & Ambígua & $5,1^{*}$ & $50,4^{*}$ & 116 & $N R^{\circ}$ \\
\hline $15^{2}$ & $\mathrm{~F}$ & Genitália ambígua ao nascimento & 0,2 & Não & Ambígua & 0,6 & $<1,0$ & 98 & 574 \\
\hline 16 & $\mathrm{~F}$ & Genitália ambígua ao nascimento & 2 & Não & Ambígua & 27 & 98,3 & 25,1 & 14,8 \\
\hline 17 & M & Genitália ambígua ao nascimento & 5 & Não & Ambígua & $<0,6^{*}$ & $<1,0^{*}$ & $<14^{*}$ & 509 \\
\hline 18 & $\mathrm{~F}$ & Amenorréia primária e virilização & 13 & Não & Clitoromegalia & 37,5 & 181 & 55 & $N R^{\circ}$ \\
\hline $19^{b}$ & M & Genitália ambígua ao nascimento & 0,9 & Não & Ambígua & $<0,6$ & $<1$ & $<14$ & 800 \\
\hline 20 & M & $\begin{array}{c}\text { Genitália ambígua ao nascimento } \\
+ \text { tumor testicular }\end{array}$ & 23 & Não & Ambígua & 11,4 & 29,2 & 420 & 468 \\
\hline $21^{b}$ & M & Genitália ambígua ao nascimento & 34 & $\operatorname{Sim}$ & Ambígua & 10 & 78 & 75 & $N R^{\circ}$ \\
\hline 22 & M & Genitália ambígua ao nascimento & 15 & Não informado & Ambígua & 12,2 & 28,1 & 84 & 304 \\
\hline $23^{b}$ & M & Genitália ambígua ao nascimento & 16 & Não informado & Ambígua & $N R^{\circ}$ & $N R^{\circ}$ & $N R^{\circ}$ & $N R^{\circ}$ \\
\hline 24 & $\mathrm{~F}$ & Genitália ambígua ao nascimento & 1,7 & Não & Ambígua & $<0,6^{*}$ & $2,7^{*}$ & 11 & 107 \\
\hline $25^{b}$ & M & Genitália ambígua ao nascimento & 7,3 & Não & Ambígua & $N R^{0}$ & $N R^{0}$ & $<10$ & $<10$ \\
\hline 26 & M & Genitália ambígua ao nascimento & 0,8 & $\operatorname{Sim}$ & Ambígua & $N R^{\circ}$ & $N R^{\circ}$ & $N R^{\circ}$ & 13 \\
\hline 27 & M & Genitália ambígua ao nascimento & 21 & Não & Ambígua & 16,5 & 49 & $<14$ & $<14$ \\
\hline $28^{3}$ & M & Genitália ambígua ao nascimento & 14 & Não & Ambígua & 11 & 57 & 12 & $N R^{\circ}$ \\
\hline $29^{3}$ & $\mathrm{M} \rightarrow \mathrm{F}$ & Genitália ambígua ao nascimento & 1,8 & Não & Ambígua & $\mathrm{NR}^{\circ}$ & $N^{\circ}$ & $<10$ & 14 \\
\hline
\end{tabular}


Tabela 19 - Dados clínicos e hormonais dos pacientes com disgenesia gonadal parcial 46, XY (conclusão)

\begin{tabular}{|c|c|c|c|c|c|c|c|c|c|}
\hline Caso & $\begin{array}{c}\text { Sexo } \\
\text { social }^{c}\end{array}$ & Quadro clínico inicial & $\begin{array}{c}\text { Idade } 1^{a} \\
\text { avaliação }^{d}\end{array}$ & $\begin{array}{c}\text { Pais } \\
\text { consangüíneos }\end{array}$ & $\begin{array}{l}\text { Genitália } \\
\text { externa }\end{array}$ & $\begin{array}{l}\mathrm{LH}^{\mathrm{e}} \\
\mathrm{UI/L}\end{array}$ & $\begin{array}{c}\mathrm{FSH}^{\mathrm{e}} \\
\mathrm{UI/L}\end{array}$ & $\begin{array}{c}\text { T basal }^{\mathrm{e}} \\
\mathrm{ng} / \mathrm{dL}\end{array}$ & $\begin{array}{c}\text { T após } \mathrm{hCG}^{\mathrm{e}} \\
\mathrm{ng} / \mathrm{dL}\end{array}$ \\
\hline 30 & M & Genitália ambígua ao nascimento & 12 & Não & Ambígua & $\mathrm{NR}^{0}$ & $\mathrm{NR}^{0}$ & $\mathrm{NR}^{\circ}$ & $N R^{\circ}$ \\
\hline 31 & M & Micropênis & 23 & Não & Micropênis & 370 & 64 & 175 & 150 \\
\hline 32 & $\mathrm{M} \rightarrow \mathrm{F}$ & Micropênis & 30 & Não & Ambígua & 10 & 39,7 & 29 & 44 \\
\hline 33 & M & Micropênis & 16 & Não & Micropênis & $\mathrm{NR}^{0}$ & $N R^{\circ}$ & $N R^{\circ}$ & $N R^{0}$ \\
\hline 34 & M & Criptorquidia e micropênis & 1,8 & Não & Ambígua & 11,8 & 115 & 9 & 9 \\
\hline $35^{b}$ & $\mathrm{~F}$ & Genitália ambígua ao nascimento & 23 & Não & Ambígua & 41,7 & 8 & 24 & $N R^{0}$ \\
\hline $36^{b}$ & $\mathrm{~F}$ & Genitália ambígua ao nascimento & 43 & Não & Ambígua & 31,7 & 51,9 & 324 & $N R^{0}$ \\
\hline $37^{\mathrm{b}}$ & M & Criptorquidia e micropênis & 3,5 & Não & Ambígua & $3 *$ & $88^{*}$ & $<10$ & 29 \\
\hline 38 & $\mathrm{~F}$ & Amenorréia primária & 15 & Não & Clitorome-galia & 74 & 96 & 36 & 40,2 \\
\hline $39^{4}$ & M & Genitália ambígua ao nascimento & 11,5 & Não & Ambígua & 20 & 41 & $<7$ & $N R^{0}$ \\
\hline $40^{4}$ & $\mathrm{~F}$ & Genitália ambígua ao nascimento & 18 & Não & Feminina & 43 & 97 & 14 & $N R^{0}$ \\
\hline \multirow[t]{5}{*}{41} & $\mathrm{M} \rightarrow \mathrm{F}$ & Genitália ambígua ao nascimento & 4 & $\operatorname{Sim}$ & Ambígua & 3,2 & 87 & 30 & $<10$ \\
\hline & & Valores & Normais & IFME* & Crianças & $0,6-1,3^{*}$ & $\begin{array}{l}1,0- \\
3,1^{*}\end{array}$ & & \\
\hline & & & & & Adultos & $1,4-9,2^{*}$ & $1,0-12^{*}$ & & \\
\hline & & & & RIE & Crianças & $1,0-10$ & $1,0-10$ & $<30$ & $391 \pm 129$ \\
\hline & & & & & Adultos & $1,0-10$ & $1,0-10$ & $441-925$ & $1306 \pm 577$ \\
\hline
\end{tabular}

$\overline{2,3,4}$ casos familiares 2,3 e $4 ;{ }^{b}$ manipulação cirúrgica prévia; ${ }^{\mathrm{C}}$ Feminino, M-Masculino, $\mathrm{M} \rightarrow \mathrm{F}$ - mudança de sexo social de masculino para feminino; ${ }^{\mathrm{d}}$ anos; ${ }^{\mathrm{e}}$ exames hormonais pré-operatórios; * IFME- método imunofluorométrico; RIE- método radioimunoensaio; $\mathrm{NR}^{\circ}$ - exame não realizado 
Tabela 20 - Genitais internos e exame anatomopatológico dos pacientes com disgenesia gonadal parcial 46, XY

\begin{tabular}{|c|c|c|c|c|c|}
\hline Caso & US pélvico útero & $\begin{array}{c}\text { UCGR }^{c} \\
\text { Seio urogenital }\end{array}$ & AP: Gônadas ${ }^{d}$ & $\begin{array}{l}\text { AP: Derivados } \\
\text { Müllerianos }^{d}\end{array}$ & $\begin{array}{l}\text { AP: Derivados } \\
\text { Wolffianos }^{d}\end{array}$ \\
\hline $14^{2}$ & Presente & Presente & $D^{f}$ à esquerda $+D^{f}$ à direita & $\mathrm{U}^{\mathrm{i}}$ e $\mathrm{T}^{\mathrm{j}}$ bilaterais & Ausentes \\
\hline $15^{2}$ & Ausente & Presente & $D^{f}$ à esquerda $+D^{f}$ à direita & $\mathrm{T}^{\mathrm{j}}$ bilaterais & $E^{k}$ e $V^{\prime}$ bilaterais \\
\hline 16 & Ausente & Presente & $D^{f}$ à esquerda $+D^{f}$ à direita & $\mathrm{T}^{\mathrm{j}}$ bilaterais & $E^{k}$ e $V^{\prime}$ bilaterais \\
\hline 17 & $\mathrm{NR}^{\circ}$ & Presente & * & $U^{i}$ rudimentar & Ausentes \\
\hline 18 & Presente & $\mathrm{NR}^{\circ}$ & $G^{g}$ à esquerda e $D^{f}$ à direita & $\mathrm{T}^{\mathrm{j}}$ bilaterais & Ausentes \\
\hline $19^{b}$ & $\mathrm{NR}^{\circ}$ & Presente & $D^{f}$ à direita ${ }^{\star \star}$ & $\mathrm{U}^{\mathrm{i}}$ e $\mathrm{T}^{\mathrm{j}}$ bilaterais & Ausentes \\
\hline 20 & Ausente & $\mathrm{NR}^{\circ}$ & $G^{t}$ à esquerda e $D^{f}$ à direita & $\mathrm{U}^{\mathrm{i}}$ e $\mathrm{T}^{\mathrm{j}}$ esquerda & Presentes bilaterais $^{m}$ \\
\hline $21^{b}$ & $\mathrm{NR}^{\circ}$ & Ausente & $\mathrm{ND}^{\#}$ & $\mathrm{U}^{\mathrm{i}}$ e $\mathrm{T}^{\mathrm{j}}$ bilaterais & $E^{k}$ e $V^{\prime}$ bilaterais \\
\hline 22 & Ausente & Ausente & $G^{g}$ à esquerda e $D^{f}$ à direita & $\mathrm{U}^{\mathrm{i}}$ e $\mathrm{T}^{\mathrm{j}}$ bilaterais & Presentes bilaterais $^{m}$ \\
\hline $23^{b}$ & Presente & $\mathrm{NR}^{0}$ & $N D^{\#}$ & $U^{i}$ & $N^{\#}$ \\
\hline 24 & Presente & $\mathrm{NR}^{\circ}$ & $D^{f}$ à esquerda + $D^{f}$ à direita & Ausentes & $E^{k}$ e $V^{\prime}$ bilaterais \\
\hline $25^{b}$ & $\mathrm{NR}^{\circ}$ & $\mathrm{NR}^{\circ}$ & $D^{f}$ à esquerda $+D^{f}$ à direita & Ausentes & $E^{k}$ à direita \\
\hline 26 & Presente & Ausente & $D^{f}$ à esquerda + $D^{f}$ à direita & $\mathrm{U}^{\mathrm{i}}$ e $\mathrm{T}^{\mathrm{j}}$ bilaterais & Ausentes \\
\hline 27 & Ausente & $\mathrm{NR}^{\circ}$ & $N D^{\#}$ & $N^{\#}$ & $N^{\#}$ \\
\hline $28^{3}$ & Presente & Presente & $A^{h}$ à esquerda $+A^{h}$ à direita & $\mathrm{U}^{\mathrm{i}} \mathrm{T}^{\mathrm{j}}$ bilaterais & $E^{k}$ e $V^{\prime}$ bilaterais \\
\hline $29^{3}$ & Presente & Presente & $A^{h}$ à esquerda + $D^{f}$ à direita & $\mathrm{T}^{\mathrm{j}}$ à direita & $\mathrm{E}^{\mathrm{k}}$ e $\mathrm{V}^{\prime}$ à direita \\
\hline
\end{tabular}


Tabela 20 - Genitais internos e exame anatomopatológico dos pacientes com disgenesia gonadal parcial 46, XY (conclusão)

\begin{tabular}{|c|c|c|c|c|c|}
\hline Caso & US pélvico útero & $\begin{array}{c}\text { UCGR }^{\mathrm{c}} \\
\text { Seio urogenital }\end{array}$ & AP: Gônadas ${ }^{d}$ & $\begin{array}{l}\text { AP: Derivados } \\
\text { Müllerianos }^{d}\end{array}$ & $\begin{array}{l}\text { AP: Derivados } \\
\text { Wolffianos }^{d}\end{array}$ \\
\hline 30 & $\mathrm{NR}^{\circ}$ & $\mathrm{NR}^{\circ}$ & $A^{h}$ à esquerda $+D^{f}$ à direita & Ausentes & $E^{k}$ à direita \\
\hline 31 & Ausente & Ausente & $\mathrm{ND}^{\#}$ & $\mathrm{ND}^{\#}$ & $\mathrm{ND}^{\#}$ \\
\hline 32 & Ausente & Ausente & $A^{h}$ à esquerda $+A^{h}$ à direita & $\mathrm{T}^{\mathrm{j}}$ bilaterais & $E^{k}$ bilaterais \\
\hline 33 & Ausente & Ausente & $\mathrm{ND}^{\#}$ & $\mathrm{ND}^{\#}$ & $\mathrm{ND}^{\#}$ \\
\hline 34 & Ausente & $N R^{\circ}$ & $A^{h}$ à esquerda $+A^{h}$ à direita & Restos müllerianos & $E^{k}$ bilaterais \\
\hline $35^{b}$ & $N R^{\circ}$ & Ausente & $\begin{array}{l}\text { ND }^{\#} \text { (gonadectomia em outro } \\
\text { serviço) }\end{array}$ & $\mathrm{ND}^{\#}$ & $\mathrm{ND}^{\#}$ \\
\hline $36^{b}$ & Presente & $N R^{\circ}$ & $A^{h}$ à esquerda $+D^{f}$ à direita & $\mathrm{T}^{\mathrm{j}}$ à direita & $E^{k}$ à esquerda \\
\hline $37^{b}$ & Ausente & Ausente & $A^{h}$ à esquerda $+A^{h}$ à direita & Ausente & Ausentes \\
\hline 38 & Presente & Presente & $A^{h}$ à esquerda $+D^{f}$ à direita. & $\mathrm{T}^{\mathrm{j}}$ bilaterais & $E^{k}$ à direita \\
\hline $39^{4}$ & Ausente & Presente & $A^{h}$ à esquerda $+A^{h}$ à direita & Ausentes & $\mathrm{E}^{\mathrm{k}}$ bilaterais \\
\hline $40^{4}$ & $N R^{\circ}$ & Presente & $D^{f}$ à esquerda $+A^{h}$ à direita & Ausentes & $\mathrm{E}^{\mathrm{k}}$ bilaterais \\
\hline 41 & Ausente & Presente & $D^{f}$ à esquerda $+A^{h}$ à direita & $\mathrm{U}^{\mathrm{i}}$ e $\mathrm{T}^{\mathrm{j}}$ bilaterais & Ausentes \\
\hline
\end{tabular}

${ }_{2,3,4}$ casos familiares 2,3 e $4 ;{ }^{b}$ manipulação cirúrgica prévia; ${ }^{c}$ UCGR- Uretrocistografia retrógrada; ${ }^{d}$ AP- Anatomopatológico; $D^{f}$ - gônada disgenética; $G^{g}$ -

gonadoblastoma; $G^{t}$ - tumor misto de células germinativas; $A^{\mathrm{h}}$ - gônada ausente; $U^{\mathrm{i}}$ - útero; $\mathrm{T}^{\mathrm{j}}$ - tuba uterina; $\mathrm{E}^{\mathrm{k}}$ - epidídimo; $\mathrm{V}^{\prime}$ - vaso deferente; ${ }^{\mathrm{m}}$ derivados $\mathrm{Wolffianos}$ não especificados; ${ }^{*}$ não retiradas gônadas; ${ }^{* *}$ não retirada gônada esquerda; NR ${ }^{\circ}$ - exame não realizado; ND ${ }^{\#}$ - material não disponível 
Tabela 21 - Dados clínicos e hormonais das pacientes com DDG 46, XX

\begin{tabular}{|c|c|c|c|c|c|c|c|c|}
\hline Caso & Diag-nósticob & Quadro clínico inicial ${ }^{c}$ & $\begin{array}{c}\text { Idade } 1^{a} \\
\text { avaliação }^{d}\end{array}$ & $\begin{array}{c}\text { Pais } \\
\text { consangüíneo } \\
\text { s } \\
\end{array}$ & Doenças associadas & $\begin{array}{l}\mathrm{LH}^{\mathrm{g}} \\
\mathrm{UI} / \mathrm{L}\end{array}$ & $\begin{array}{c}\mathrm{FSH}^{\mathrm{g}} \\
\mathrm{UI} / \mathrm{L}\end{array}$ & $\begin{array}{c}E_{2} \text { inicial }^{g} \\
(\mathrm{pg} / \mathrm{mL})\end{array}$ \\
\hline $42^{6}$ & DG $46, X X$ & Ausência de T e M & 17 & Não & Atraso do $\mathrm{DNPM}^{\dagger}$ & 31 & 74 & $<13$ \\
\hline $43^{6}$ & DG $46, X X$ & Ausência de T e M & 17 & Não & Atraso do DNPM ${ }^{\dagger}$ & 46 & 117 & $<13$ \\
\hline $44^{7}$ & DG $46, X X$ & Ausência de M & 17 & $\operatorname{Sim}^{\mathrm{e}}$ & Não & 11 & 32 & $<13$ \\
\hline $45^{7}$ & DG $46, X X$ & Ausência de T e M & 12 & $\operatorname{Sim}^{\mathrm{e}}$ & Não & 4,7 & 12 & $<13$ \\
\hline $46^{8}$ & DG $46, X X$ & Ausência de T e M & 15 & Não & Não & 24 & 95 & $<6,8$ \\
\hline $47^{8}$ & DG $46, X X$ & Ausência de T e M & 18 & Não & Não & 39 & 111 & 37 \\
\hline $48^{9}$ & DG $46, X X$ & Ausência de T e M & 17 & Sim & $\begin{array}{c}\text { Doença de Wilson e } \\
\text { ceratocone }\end{array}$ & 11,9 & 46,2 & 18,4 \\
\hline $49^{9}$ & DG $46, X X$ & Ausência de T e M & 18 & Sim & Não & 24,9 & 93,9 & $<13$ \\
\hline $50^{10}$ & DG $46, X X$ & Ausência de T e M & 21 & Sim & Hipotireoidismo primário & 16,7 & 30,6 & $<10$ \\
\hline $51^{10}$ & DG $46, X X$ & Ausência de T e M & 28 & Sim & Hipotireoidismo primário & 21 & 44 & $<13$ \\
\hline 52 & FOP & $\begin{array}{c}\text { Menarca atrasada e } \\
\text { amenorréia secundária }\end{array}$ & 20 & Sim & $\begin{array}{c}\text { Hipoacusia } \\
\text { neurossensorial bilateral }\end{array}$ & 15 & 47,6 & $<20$ \\
\hline 53 & DG $46, X X$ & Ausência de T e M & 26 & Não & Não & 47 & 138 & $<13$ \\
\hline 54 & DG $46, X X$ & Ausência de T e M & 14 & Não & $\begin{array}{c}\text { Alteração congênita na } \\
\text { mão }\end{array}$ & 29 & 99,9 & $<13$ \\
\hline 55 & DG $46, X X$ & Ausência de M & 30 & Não & Não & 20 & 40,7 & 45 \\
\hline 56 & DG $46, X X$ & Ausência de T e M & 19 & Não & Não & 55,5 & 119 & $<13$ \\
\hline
\end{tabular}

continua 
Tabela 21 - Dados clínicos e hormonais das pacientes com DDG 46, XX (conclusão)

\begin{tabular}{|c|c|c|c|c|c|c|c|c|}
\hline Caso & Diag-nóstico ${ }^{b}$ & Quadro clínico inicial ${ }^{c}$ & 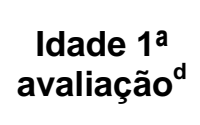 & $\begin{array}{c}\text { Pais } \\
\text { consangüíneos }\end{array}$ & Doenças associadas & $\begin{array}{l}\mathrm{LH}^{\mathrm{g}} \\
\mathrm{UI/L}\end{array}$ & $\begin{array}{c}\text { FSH }^{\mathrm{g}} \\
\text { UI/L }\end{array}$ & $\begin{array}{c}E_{2} \text { inicial }^{g} \\
(p g / m L)\end{array}$ \\
\hline 57 & DG $46, X X$ & Ausência de T e M & 17 & Sim & $\begin{array}{l}\text { Atraso do DNPM' } \\
\text { convulsões }\end{array}$ & 22,5 & 75,8 & $<13$ \\
\hline 58 & DG $46, X X$ & Ausência de T e M & 14 & Não & Eflúvio telógeno crônico & 7,8 & 28 & $<13$ \\
\hline 59 & FOP & $\begin{array}{l}\text { Ciclos menstruais irregulares } \\
\text { e amenorréia secundária }\end{array}$ & 20 & Não & Não & 12,6 & 33,6 & $<20$ \\
\hline \multirow[t]{3}{*}{$60^{5}$} & DG $46, X X$ & Ausência de T e M & 15 & $\operatorname{Sim}$ & Não & 56 & 48 & 30 \\
\hline & & & & IFME* & Crianças & $<0,6-1,3$ & $1,0-3,1$ & $<24$ \\
\hline & & & & & Adultas & $0,95-9,3$ & $1,7-9,3$ & $35-540$ \\
\hline
\end{tabular}

$\overline{5,6,7,8,9,10}$ casos familiares 5, 6, 7, 8, 9, 10; ${ }^{\mathrm{b}}$ Sd- Síndrome de Perrault, DG- disgenesia gonadal, FOP- falência ovariana prematura; ${ }^{\mathrm{C}} \mathrm{T}$-Telarca, M- menarca; ${ }^{\mathrm{d}}$ anos; ${ }^{\mathrm{e}}$ avós também consangüíneos; ${ }^{f}$ DNPM- desenvolvimento neuropsicomotor; ${ }^{g}$ exames pré tratamento hormonal; ${ }^{*}$ IFME- método imunofluorométrico; NR ${ }^{\circ}$ - exame não realizado. 
Tabela 22 - Genitais internos e auto-anticorpos das pacientes com DDG 46, XX

\begin{tabular}{|c|c|c|}
\hline Caso & Auto-anticorpos $^{\text {b }}$ & US pélvico ${ }^{c, d}$ \\
\hline $42^{6}$ & Ac anti-célula esteroidal e anti-TPO negativos & Útero hipoplásico de 3,74 cm3. Ovários não visualizados \\
\hline $43^{6}$ & Ac anti-célula esteroidal e anti-TPO negativos & $N R^{0}$ \\
\hline $44^{7}$ & Ac anti-célula esteroidal negativo & Útero hipoplásico, ovários não visualizados \\
\hline $45^{7}$ & Ac anti-célula esteroidal negativo & Útero de 1,3 cm no maior diâmetro, ovários não identificados \\
\hline $46^{8}$ & Acs anti-tireoglobulina e anti-TPO negativos & Útero de 1,15 cm $\mathrm{cm}^{3}$ OD: $0,96 \mathrm{~cm}^{3}, \mathrm{OE}: 1,38 \mathrm{~cm}^{3}$ \\
\hline $47^{8}$ & $\begin{array}{c}\text { Acs anti-mitocondrial, anti-músculo liso, anti-citosol hepático, } \\
\text { fatores anti-nucleares negativos }\end{array}$ & Útero hipoplásico, ovários reduzidos. \\
\hline $48^{9}$ & Ac anti-célula esteroidal negativo & Útero de $12 \mathrm{~cm}^{3}$ \\
\hline $49^{9}$ & Ac anti-célula esteroidal negativo & $N R^{\circ}$ \\
\hline $50^{10}$ & Acs anti-tireoglobulina e anti-TPO negativos & Útero hipoplásico, OD de dimensões reduzidas; OE não visualizado. \\
\hline $51^{10}$ & Acs anti-tireoglobulina, anti-TPO, anti-célula esteroidal negativos & Útero de $9,3 \mathrm{~cm}^{3}, \mathrm{OD}: 1,1 \mathrm{~cm}^{3}, \mathrm{OE}: 1,1 \mathrm{~cm}^{3}$ \\
\hline 52 & $\begin{array}{l}\text { Acs anti-tireoglobulina, anti-TPO, anti-mitocondrial, } \\
\text { fatores antinucleares, anti-músculo liso, anti-citosol hepático, } \\
\text { fator reumatóide, fatores anti-nucleares negativos }\end{array}$ & Útero $23 \mathrm{~cm}^{3}$, OD $5 \mathrm{~cm}^{3}$; OE: $5,5 \mathrm{~cm}^{3}$ \\
\hline 53 & Ac anti-célula esteroidal negativo & Hipoplasia uterina \\
\hline 54 & Acs anti-tireoglobulina e anti-TPO negativos & Útero de $3,1 \mathrm{~cm}^{3}$, ovários não visualizados \\
\hline 55 & Ac anti-célula esteroidal negativo & Útero de $11 \mathrm{~cm}^{3}, \mathrm{OD}: 0,8 \mathrm{~cm}^{3}, \mathrm{OE}: 1,0 \mathrm{~cm}^{3}$ \\
\hline 56 & Ac anti-célula esteroidal negativo & Útero hipoplásico e ovários de dimensões reduzidas \\
\hline 57 & Ac anti-célula esteroidal negativo & Útero de $11 \mathrm{~cm}^{3}$, ovários não visualizados \\
\hline 58 & Acs anti-célula esteroidal e anti-adrenal negativos & Útero $6 \mathrm{~cm}^{3}, \mathrm{OD}: 3,6 \mathrm{~cm}^{3}, \mathrm{OE}: 0,6 \mathrm{~cm}^{3}$ \\
\hline 59 & Ac anti-célula esteroidal negativo & $N R^{\circ}$ \\
\hline $60^{5}$ & $\mathrm{NR}^{\circ}$ & Útero de $5,6 \mathrm{~cm}^{3}$ \\
\hline & & $\begin{array}{l}\text { Valor normal de útero em adultos: } 30-90 \mathrm{~cm}^{3} \\
\text { Valor normal de ovários em adultos: } 3 \text { a } 9 \mathrm{~cm}^{3}\end{array}$ \\
\hline
\end{tabular}


Anexo D - Tabela das variantes alélicas do gene $C B X 2$

Tabela 23 - Variantes alélicas e sua localização no gene CBX2

\begin{tabular}{|c|c|c|c|c|c|}
\hline Exon/Intron & Variante Alélica & $\begin{array}{c}N^{\circ} \text { pctes } \\
X Y\end{array}$ & $\begin{array}{c}\mathrm{N}^{\circ} \text { pctes } \\
\mathrm{XX}\end{array}$ & $\begin{array}{l}\mathbf{N}^{\circ} \text { pctes total } l \\
\text { freqüência } \\
\text { alélica }\end{array}$ & $\begin{array}{c}\text { Indivíduos } \\
\text { normais } \\
\text { (freqüência } \\
\text { alélica) } \\
\end{array}$ \\
\hline Região $N T^{1} 5^{\prime}$ & g. $-132 \mathrm{G}>\mathrm{A}$ & 2 & 4 & $06 / 05 \%$ & $8,19 \%$ \\
\hline Região $\mathrm{NT}^{1} 5^{\prime}$ & g. $-74 T>C$ & 1 & 0 & $01 / 0,83 \%$ & $4,03 \%$ \\
\hline Região $N T^{1} 5^{\prime}$ & g. $-52 C>G$ & 41 & 19 & $60 / 100 \%$ & $N D^{*}$ \\
\hline Intron 1 & g.IVS1+37 & 0 & 2 & 02 / 1,67\% & $4,09 \%$ \\
\hline Intron 1 & g.IVS1+41 & 3 & 3 & $06 / 05 \%$ & $15,57 \%$ \\
\hline Exon 3 & p.|49| & 1 & 1 & 02 / 1,67\% & $N D^{*}$ \\
\hline Intron 3 & $\underset{\text { g.IVS3+20_21dup }}{\cos }$ & 14 & 11 & $25 / 24,17 \%$ & $N D^{*}$ \\
\hline Exon 4 & p.C132R & 1 & 0 & $01 / 0,83 \%$ & 0 \\
\hline Exon 4 & p.F194L & 1 & 0 & $1 / 0,83 \%$ & $N D^{*}$ \\
\hline Exon 5 & P201P & 4 & 1 & $05 / 4,17 \%$ & $N D^{*}$ \\
\hline Exon 5 & L414L & 17 & 10 & $27 / 22,5 \%$ & $N D^{*}$ \\
\hline Exon 5 & $\mathrm{~A} 452 \mathrm{~V}$ & 4 & 0 & $04 / 3,33 \%$ & $2,85 \%$ \\
\hline Exon 5 & P483P & 21 & 10 & $31 / 25,83 \%$ & $N D^{*}$ \\
\hline
\end{tabular}

${ }^{1}$-Região não traduzida; ${ }^{*}$ ND: freqüência não disponível (polimorfismo já descrito) 
8 Referências 
1. Kim Y, Capel B. Balancing the bipotential gonad between alternative organ fates: a new perspective on an old problem. Dev Dyn 2006;235:2292-300.

2. Cummings AM, Kavlock RJ. Function of sexual glands and mechanism of sex differentiation. J Toxicol Sci 2004;29:167-78.

3. Jost A, Magre S, Agelopoulou R. Early stages of testicular differentiation in the rat. Hum Genet 1981;58:59-63.

4. De Franca LR, Bartke A, Borg KE, et al. Sertoli cells in testes containing or lacking germ cells: a comparative study of paracrine effects using the W (c-kit) gene mutant mouse model. Anat Rec 1994;240:225-32.

5. Merchant-Larios $\mathrm{H}$, Centeno $\mathrm{B}$. Morphogenesis of the ovary from the sterile W/Wv mouse. Prog Clin Biol Res 1981;59B:383-92.

6. Jost A. A new look at the mechanisms controlling sex differentiation in mammals. Johns Hopkins Med J 1972;130:38-53.

7. Parker KL, Schimmer BP. Genes essential for early events in gonadal development. Ann Med 2002;34:171-8.

8. Lee PA, Houk CP, Ahmed SF, Hughes IA. Consensus statement on management of intersex disorders. International Consensus Conference on Intersex. Pediatrics 2006;118:e488-500.

9. Mendonca BB, Domenice S, Arnhold IJ, Costa EM. 46,XY disorders of sex development (DSD). Clin Endocrinol (Oxf) 2009;70:173-87.

10. Bulun S. Disorders of the ovaries and female reproductive tract. In: Wilson JF, DW; Kronenberg, HM; Larsen, PR, ed. Williams textbook of endocrinology. 11 ed. Philadelphia: Saunders; 2008:589.

11. Simpson JL, Rajkovic A. Ovarian differentiation and gonadal failure. Am J Med Genet 1999;89:186-200.

12. Hoek A, Schoemaker J, Drexhage HA. Premature ovarian failure and ovarian autoimmunity. Endocr Rev 1997;18:107-34.

13. Marlin S, Lacombe D, Jonard L, et al. Perrault syndrome: report of four new cases, review and exclusion of candidate genes. Am J Med Genet A 2008;146A:661-4. 
14. Marcantonio SM, Fechner PY, Migeon CJ, Perlman EJ, Berkovitz GD. Embryonic testicular regression sequence: a part of the clinical spectrum of 46,XY gonadal dysgenesis. Am J Med Genet 1994;49:1-5.

15. Parker KL. The roles of steroidogenic factor 1 in endocrine development and function. Mol Cell Endocrinol 1998;140:59-63.

16. Parker KL, Schedl A, Schimmer BP. Gene interactions in gonadal development. Annu Rev Physiol 1999;61:417-33.

17. Park SY, Jameson JL. Minireview: transcriptional regulation of gonadal development and differentiation. Endocrinology 2005;146:1035-42.

18. Wilhelm D, Englert C. The Wilms tumor suppressor WT1 regulates early gonad development by activation of Sf1. Genes Dev 2002;16:1839-51.

19. Katoh-Fukui YT, R.; Shiroishi, T. et al. Male-to-female sex reversal in M33 mutant mice. Nature 1998;393:688-92.

20. Birk OS, Casiano DE, Wassif CA, et al. The LIM homeobox gene Lhx9 is essential for mouse gonad formation. Nature 2000;403:909-13.

21. Ottolenghi C, Moreira-Filho C, Mendonca BB, et al. Absence of mutations involving the LIM homeobox domain gene LHX9 in 46,XY gonadal agenesis and dysgenesis. J Clin Endocrinol Metab 2001;86:2465-9.

22. Quaggin SE, Schwartz L, Cui S, et al. The basic-helix-loop-helix protein pod1 is critically important for kidney and lung organogenesis. Development 1999;126:5771-83.

23. Cui S, Ross A, Stallings N, Parker KL, Capel B, Quaggin SE. Disrupted gonadogenesis and male-to-female sex reversal in Pod1 knockout mice. Development 2004;131:4095-105.

24. Quaggin SE, Vanden Heuvel GB, Igarashi P. Pod-1, a mesodermspecific basic-helix-loop-helix protein expressed in mesenchymal and glomerular epithelial cells in the developing kidney. Mech Dev 1998;71:37-48.

25. Raymond CS, Murphy MW, O'Sullivan MG, Bardwell VJ, Zarkower D. Dmrt1, a gene related to worm and fly sexual regulators, is required for mammalian testis differentiation. Genes Dev 2000;14:2587-95.

26. Gecz J, Gaunt SJ, Passage E, et al. Assignment of a Polycomb-like chromobox gene (CBX2) to human chromosome 17q25. Genomics 1995;26:130-3.

27. Rainier S, Johnson LA, Dobry CJ, Ping AJ, Grundy PE, Feinberg AP. Relaxation of imprinted genes in human cancer. Nature 1993;362:747-9. 
28. Ferguson-Smith AC, Sasaki H, Cattanach BM, Surani MA. Parentalorigin-specific epigenetic modification of the mouse $\mathrm{H} 19$ gene. Nature 1993;362:751-5.

29. Pearce JJ, Singh PB, Gaunt SJ. The mouse has a Polycomb-like chromobox gene. Development 1992;114:921-9.

30. Ensembl project European Bioinformatics Institute (EBI) Wellcome Trust Sanger Institute (WTSI) 2000. (Accessed 2008, at http://www.ensembl.org.)

31. Ostrer H, Huang HY, Masch RJ, Shapiro E. A cellular study of human testis development. Sex Dev 2007;1:286-92.

32. Biason-Lauber A, Konrad D, Meyer M, DeBeaufort C, Schoenle EJ. Ovaries and female phenotype in a girl with 46,XY karyotype and mutations in the CBX2 gene. Am J Hum Genet 2009;84:658-63.

33. Soyal SM, Amleh A, Dean J. FIGalpha, a germ cell-specific transcription factor required for ovarian follicle formation. Development 2000;127:4645-54.

34. Hong CY, Gong EY, Kim K, et al. Modulation of the expression and transactivation of androgen receptor by the basic helix-loop-helix transcription factor Pod-1 through recruitment of histone deacetylase 1. Mol Endocrinol 2005;19:2245-57.

35. Sinclair AH, Berta $P$, Palmer MS, et al. A gene from the human sexdetermining region encodes a protein with homology to a conserved DNA-binding motif. Nature 1990;346:240-4.

36. Quintana-Murci L, Fellous M. The Human Y Chromosome: The Biological Role of a "Functional Wasteland". J Biomed Biotechnol 2001;1:18-24.

37. Matsuo N. Fetal testis formation: a critical event for sex determination and differentiation. Acta Paediatr Jpn 1996;38:377-9.

38. Koopman P, Munsterberg A, Capel B, Vivian N, Lovell-Badge R. Expression of a candidate sex-determining gene during mouse testis differentiation. Nature 1990;348:450-2.

39. McElreavey K, Vilain E, Abbas N, Herskowitz I, Fellous M. A regulatory cascade hypothesis for mammalian sex determination: SRY represses a negative regulator of male development. Proc Natl Acad Sci U S A 1993;90:3368-72.

40. Affara NA, Chalmers IJ, Ferguson-Smith MA. Analysis of the SRY gene in 22 sex-reversed $X Y$ females identifies four new point mutations in the conserved DNA binding domain. Hum Mol Genet 1993;2:785-9. 
41. McElreavey KD, Vilain E, Boucekkine $C$, et al. $X Y$ sex reversal associated with a nonsense mutation in SRY. Genomics 1992;13:838-40.

42. Cameron FJ, Sinclair AH. Mutations in SRY and SOX9: testisdetermining genes. Hum Mutat 1997;9:388-95.

43. Domenice S, Yumie Nishi M, Correia Billerbeck $A E$, et al. A novel missense mutation (S18N) in the $5^{\prime}$ non-HMG box region of the SRY gene in a patient with partial gonadal dysgenesis and his normal male relatives. Hum Genet 1998;102:213-5.

44. Yao HH, Whoriskey W, Capel B. Desert Hedgehog/Patched 1 signaling specifies fetal Leydig cell fate in testis organogenesis. Genes Dev 2002;16:1433-40.

45. Canto $\mathrm{P}$, Soderlund D, Reyes E, Mendez JP. Mutations in the desert hedgehog $(\mathrm{DHH})$ gene in patients with $46, \mathrm{XY}$ complete pure gonadal dysgenesis. J Clin Endocrinol Metab 2004;89:4480-3.

46. Umehara F, Tate $\mathrm{G}$, Itoh $\mathrm{K}$, et al. A novel mutation of desert hedgehog in a patient with 46,XY partial gonadal dysgenesis accompanied by minifascicular neuropathy. Am J Hum Genet 2000;67:1302-5.

47. Clark AM, Garland KK, Russell LD. Desert hedgehog (Dhh) gene is required in the mouse testis for formation of adult-type Leydig cells and normal development of peritubular cells and seminiferous tubules. Biol Reprod 2000;63:1825-38.

48. Wilhelm D, Palmer S, Koopman P. Sex determination and gonadal development in mammals. Physiol Rev 2007;87:1-28.

49. Ross AJ, Capel B. Signaling at the crossroads of gonad development. Trends Endocrinol Metab 2005;16:19-25.

50. Swain A, Zanaria E, Hacker A, Lovell-Badge R, Camerino G. Mouse Dax1 expression is consistent with a role in sex determination as well as in adrenal and hypothalamus function. Nat Genet 1996;12:404-9.

51. Jeffs $B$, Meeks $\mathrm{JJ}$, Ito $M$, et al. Blockage of the rete testis and efferent ductules by ectopic Sertoli and Leydig cells causes infertility in Dax1deficient male mice. Endocrinology 2001;142:4486-95.

52. Bullejos $M$, Bowles $J$, Koopman $P$. Extensive vascularization of developing mouse ovaries revealed by caveolin-1 expression. Dev Dyn 2002;225:95-9.

53. Pailhoux E, Cribiu EP, Chaffaux S, Darre R, Fellous M, Cotinot C. Molecular analysis of $60, \mathrm{XX}$ pseudohermaphrodite polled goats for the presence of SRY and ZFY genes. J Reprod Fertil 1994;100:491-6. 
54. Harris SE, Chand AL, Winship IM, Gersak K, Aittomaki K, Shelling AN. Identification of novel mutations in FOXL2 associated with premature ovarian failure. Mol Hum Reprod 2002;8:729-33.

55. Schmidt D, Ovitt CE, Anlag $\mathrm{K}$, et al. The murine winged-helix transcription factor Foxl2 is required for granulosa cell differentiation and ovary maintenance. Development 2004;131:933-42.

56. Yao $\mathrm{HH}$. The pathway to femaleness: current knowledge on embryonic development of the ovary. Mol Cell Endocrinol 2005;230:87-93.

57. Merchant $\mathrm{H}$. Rat gonadal and ovarioan organogenesis with and without germ cells. An ultrastructural study. Dev Biol 1975;44:1-21.

58. McLaren A. Meiosis and differentiation of mouse germ cells. Symp Soc Exp Biol 1984;38:7-23.

59. Behringer RR, Cate RL, Froelick GJ, Palmiter RD, Brinster RL. Abnormal sexual development in transgenic mice chronically expressing mullerian inhibiting substance. Nature 1990;345:167-70.

60. Vainio S, Heikkila M, Kispert A, Chin N, McMahon AP. Female development in mammals is regulated by Wnt-4 signalling. Nature 1999;397:405-9.

61. Menke DB, Koubova J, Page DC. Sexual differentiation of germ cells in $X X$ mouse gonads occurs in an anterior-to-posterior wave. Dev Biol 2003;262:303-12.

62. Yao HH, Matzuk MM, Jorgez CJ, et al. Follistatin operates downstream of Wnt4 in mammalian ovary organogenesis. Dev Dyn 2004;230:210-5.

63. Jeays-Ward K, Hoyle C, Brennan J, et al. Endothelial and steroidogenic cell migration are regulated by WNT4 in the developing mammalian gonad. Development 2003;130:3663-70.

64. Arnhold IJ, Latronico AC, Batista MC, Mendonca BB. Menstrual disorders and infertility caused by inactivating mutations of the luteinizing hormone receptor gene. Fertil Steril 1999;71:597-601.

65. Aittomaki K, Lucena JL, Pakarinen $\mathrm{P}$, et al. Mutation in the folliclestimulating hormone receptor gene causes hereditary hypergonadotropic ovarian failure. Cell 1995;82:959-68.

66. Beau I, Touraine P, Meduri G, et al. A novel phenotype related to partial loss of function mutations of the follicle stimulating hormone receptor. $\mathrm{J}$ Clin Invest 1998;102:1352-9.

67. Touraine P, Beau I, Gougeon A, et al. New natural inactivating mutations of the follicle-stimulating hormone receptor: correlations between receptor function and phenotype. Mol Endocrinol 1999;13:1844-54. 
68. Crisponi $L$, Deiana $M$, Loi $A$, et al. The putative forkhead transcription factor FOXL2 is mutated in blepharophimosis/ptosis/epicanthus inversus syndrome. Nat Genet 2001;27:159-66.

69. Gersak K, Harris SE, Smale WJ, Shelling AN. A novel 30 bp deletion in the FOXL2 gene in a phenotypically normal woman with primary amenorrhoea: case report. Hum Reprod 2004;19:2767-70.

70. De Baere E, Lemercier B, Christin-Maitre S, et al. FOXL2 mutation screening in a large panel of POF patients and XX males. J Med Genet 2002;39:e43.

71. Bodega B, Porta C, Crosignani PG, Ginelli E, Marozzi A. Mutations in the coding region of the FOXL2 gene are not a major cause of idiopathic premature ovarian failure. Mol Hum Reprod 2004;10:555-7.

72. Male Pseudohermaphroditism. Endotext.com, 2005. (Accessed december, 2008, at http://www.endotext.org/pediatrics/pediatrics11/pediatricsframe11.htm.)

73. de la Chesnaye E, Canto P, Ulloa-Aguirre A, Mendez JP. No evidence of mutations in the follicle-stimulating hormone receptor gene in Mexican women with 46,XX pure gonadal dysgenesis. Am J Med Genet 2001;98:125-8.

74. Correa RV, Domenice S, Bingham NC, et al. A microdeletion in the ligand binding domain of human steroidogenic factor 1 causes $X Y$ sex reversal without adrenal insufficiency. $J$ Clin Endocrinol Metab 2004;89:1767-72.

75. Arnhold IJ, Mendonca BB, Diaz JA, et al. Prepubertal male pseudohermaphroditism due to 17-ketosteroid reductase deficiency: diagnostic value of a hCG test and lack of HLA association. J Endocrinol Invest 1988;11:319-22.

76. Beilguelman B. Citogenética humana. Rio de Janeiro: Guanabara Koogan; 1986.

77. Winqvist O, Gebre-Medhin G, Gustafsson J, et al. Identification of the main gonadal autoantigens in patients with adrenal insufficiency and associated ovarian failure. J Clin Endocrinol Metab 1995;80:1717-23.

78. Betterle C, Rossi A, Dalla Pria S, et al. Premature ovarian failure: autoimmunity and natural history. Clin Endocrinol (Oxf) 1993;39:35-43.

79. Goswami D, Conway GS. Premature ovarian failure. Horm Res 2007;68:196-202.

80. Miller SA, Dykes DD, Polesky HF. A simple salting out procedure for extracting DNA from human nucleated cells. Nucleic Acids Res 1988;16:1215. 
81. Primer3 Howard Hughes Medical Institute, National Institutes of Health and National Human Genome Research Institute (Accessed 2005-2008, at http://frodo.wi.mit.edu/.)

82. Schonberger J, Levy H, Grunig E, et al. Dilated cardiomyopathy and sensorineural hearing loss: a heritable syndrome that maps to 6q23-24. Circulation 2000;101:1812-8.

83. Sarafoglou K, Ostrer $H$. Clinical review 111: familial sex reversal: a review. J Clin Endocrinol Metab 2000;85:483-93.

84. Grumbach MM. Disorders of sex differentiation. In: Larsen PR, ed. Williams Textbook of Endocrinology. 10 ed. Philadelphia: Elsevier Science; 2003.

85. Cools M, Stoop H, Kersemaekers AM, et al. Gonadoblastoma arising in undifferentiated gonadal tissue within dysgenetic gonads. J Clin Endocrinol Metab 2006;91:2404-13.

86. Lopez-Lopez M, Zenteno JC, Mendez JP, Kofman-Alfaro S. [Genetic heterogeneity and phenotypic variability in $46, X Y$ sex reversal]. Rev Invest Clin 1998;50:171-6.

87. Perrault M, Klotz B, Housset E. [Two cases of Turner syndrome with deafmutism in two sisters.]. Bull Mem Soc Med Hop Paris 1951;67:79-84.

88. Bitgood MJ, Shen L, McMahon AP. Sertoli cell signaling by Desert hedgehog regulates the male germline. Curr Biol 1996;6:298-304.

89. Berkeley Drosophila Genome Project (BDGP) National Human Genome Research Institute, National Cancer Institute, and Howard Hughes Medical Institute (Accessed 2006, at http://www.fruitfly.org/seq tools/splice.html.) 